\title{
SLUDGE BATCH 3 QUALIFICATION IN THE SRTC SHIELDED CELLS
}

\author{
J. M. Pareizs \\ D. C. Koopman \\ D. R. Click \\ A. D. Cozzi \\ N. E. Bibler
}

May 2004

Immoblization Technology Section Savannah River Technology Center Aiken, SC 29808 
This document was prepared in conjunction with work accomplished under Contract No. DE-AC09-96SR18500 with the U. S. Department of Energy.

\section{DISCLAIMER}

This report was prepared as an account of work sponsored by an agency of the United States Government. Neither the United States Government nor any agency thereof, nor any of their employees, makes any warranty, express or implied, or assumes any legal liability or responsibility for the accuracy, completeness, or usefulness of any information, apparatus, product or process disclosed, or represents that its use would not infringe privately owned rights. Reference herein to any specific commercial product, process or service by trade name, trademark, manufacturer, or otherwise does not necessarily constitute or imply its endorsement, recommendation, or favoring by the United States Government or any agency thereof. The views and opinions of authors expressed herein do not necessarily state or reflect those of the United States Government or any agency thereof.

This report has been reproduced directly from the best available copy.

Available for sale to the public, in paper, from: U.S. Department of Commerce, National Technical Information Service, 5285 Port Royal Road, Springfield, VA 22161, phone: (800) 553-6847, fax: (703) 605-6900

email: orders@ntis.fedworld.gov

online ordering: http://www.ntis.gov/help/index.asp

Available electronically at http://www.osti.gov/bridge

Available for a processing fee to U.S. Department of Energy and its contractors, in paper, from: U.S. Department of Energy, Office of Scientific and Technical Information, P.O. Box 62, Oak Ridge, TN 37831-0062,

phone: (865)576-8401,

fax: (865)576-5728

email: $\underline{\text { reports@ adonis.osti.gov }}$ 
Key Words: DWPF, SRAT, WASTE QUALIFICATION, SB3, SME, SHIELDED CELLS

Retention: PERMANENT

\title{
SLUDGE BATCH 3 QUALIFICATION IN THE SRTC SHIELDED CELLS
}

\author{
J. M. Pareizs \\ D. C. Koopman \\ D. R. Click \\ A. D. Cozzi \\ N. E. Bibler
}

May 2004

Immoblization Technology Section Savannah River Technology Center Aiken, SC 29808 
This page was intentionally left blank 


\section{EXECUTIVE SUMMARY}

The Defense Waste Processing Facility (DWPF) has requested that a radioactive demonstration of the next batch of sludge slurry (Sludge Batch 3) be completed in the Shielded Cells Facility of the Savannah River Technology Center (SRTC). Sludge Batch 3 (SB3) consists of the heel in Tank 51, which included Plutonium $(\mathrm{Pu})$ and Americium/Curium $(\mathrm{Am} / \mathrm{Cm})$ transferred from $\mathrm{H}$ and $\mathrm{F}$ Canyon, respectively; sludge slurry from Tank 7 (including sludge transferred into Tank 7 from Tanks 18 and 19); additional Pu transferred from $\mathrm{H}$ Canyon; a Neptunium ( $\mathrm{Np}$ ) transfer also from H Canyon; and the remaining Sludge Batch 2 material in Tank $40^{*}$. Because the current contents of Tank 40 (Sludge Batch 2) have already been qualified, this qualification work did not include the contribution of Tank 40.

SRTC began this qualification task with a sample from Tank 51. This sample was received prior to several Closure Business Unit (CBU) planned decants and additions. Therefore, these decants and additions were completed by SRTC based upon CBU July 2003 plans. The sample was then used in a DWPF Sludge Receipt and Adjustment Tank (SRAT) cycle and a Slurry Mix Evaporator (SME) cycle. Glass was fabricated and evaluated for durability.

During SRTC processing,

- Hydrogen generation rates and nitrous oxide concentrations during the SRAT and SME cycles were below DWPF limits,

- Nitrite was destroyed and mercury was removed during the SRAT cycle,

- No processing problems (excessive foaming, loss of heat transfer, inability to mix) were observed during processing,

- The glass fabricated with this material was acceptable based on the Product Consistency Test (PCT).

\footnotetext{
* DWPF started processing SB3 in March 2004. Due to equipment problems in Tank 51 and H-Canyon, not all the material in Tank 51 or the Np in H-Canyon was transferred into SB3. Current plans are to transfer the remaining Np and sludge in April and May 2004, respectively. It should be emphasized that SRTC qualification work was based on Tank 51 contents plus all of the planned Np material; these delays in transfers do not affect the qualification work.
} 


\section{TABLE OF CONTENTS}

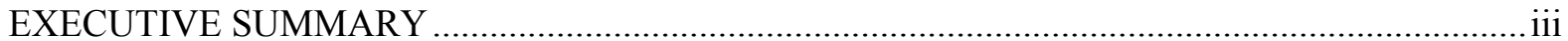

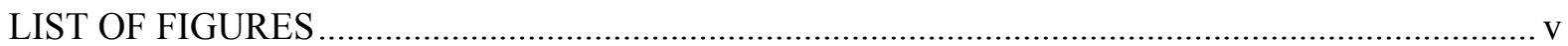

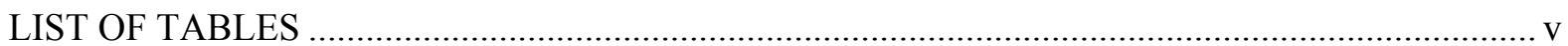

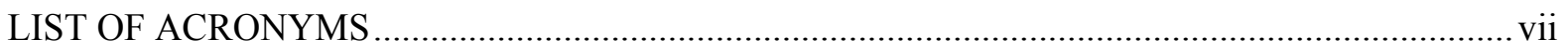

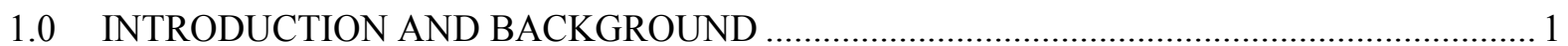

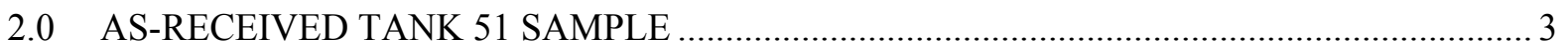

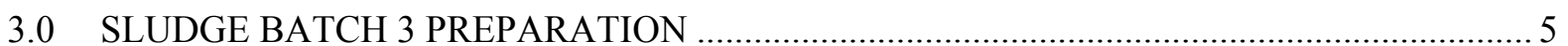

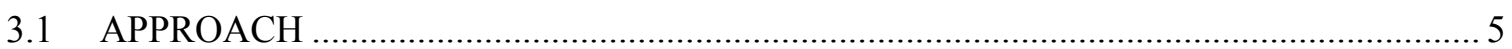

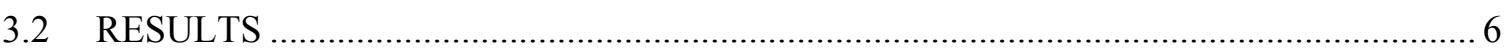

4.0 SRAT CYCLE

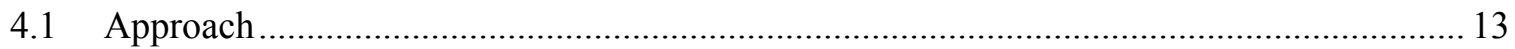

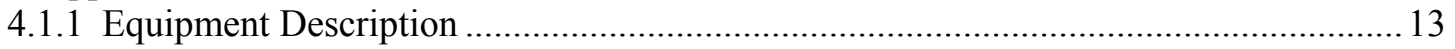

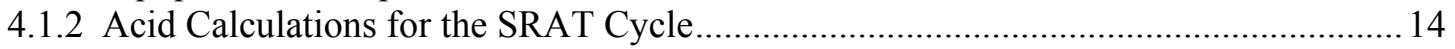

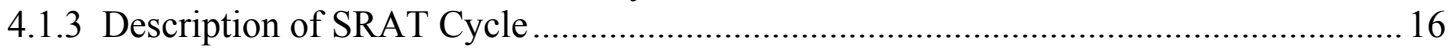

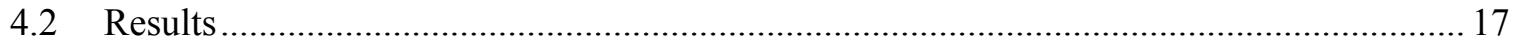

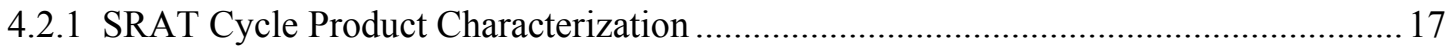

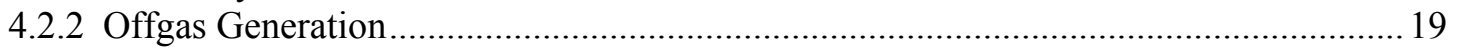

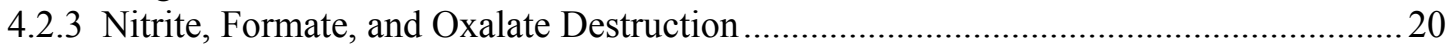

4.2.4 Elements Dissolved From the Sludge During the SRAT Cycle ……............................20

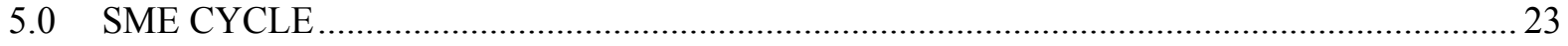

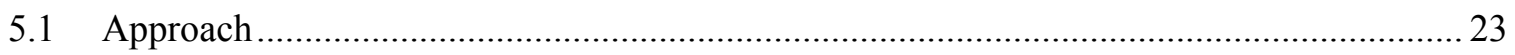

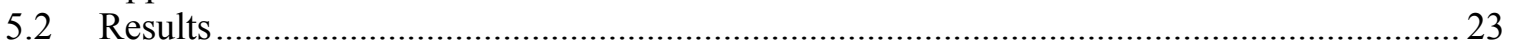

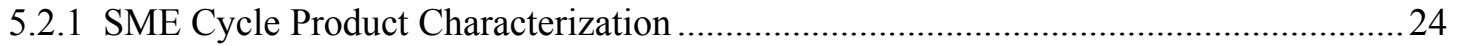

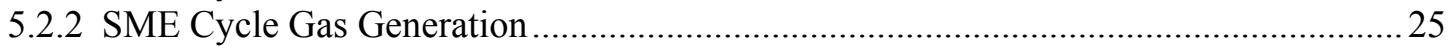

5.2.3 Overall Anion destruction/conversion and Comparison to Acid Calculation

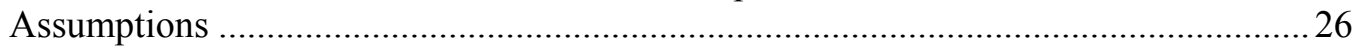

6.0 FORMIC ACID ADDITION

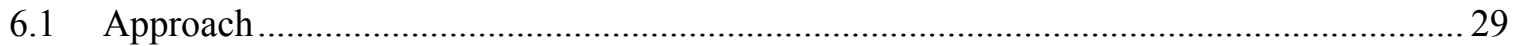

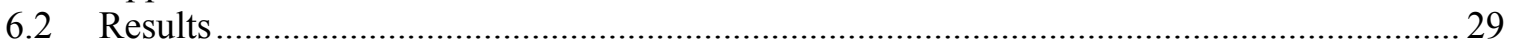

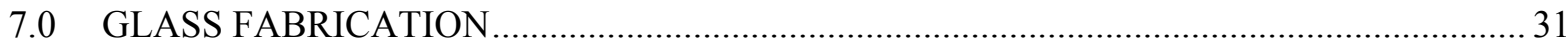

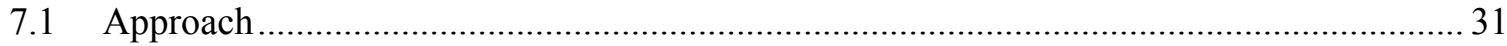

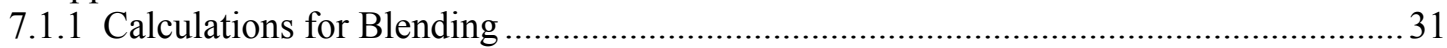

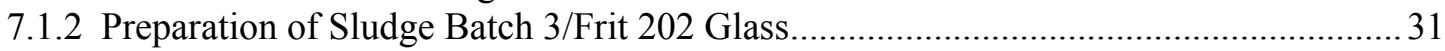

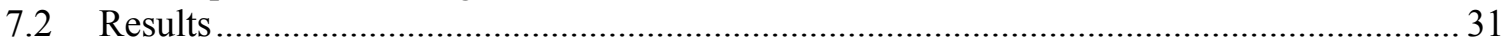

7.2.1 Chemical Composition of Sludge Batch 3/Frit 202 Glass ............................................ 31

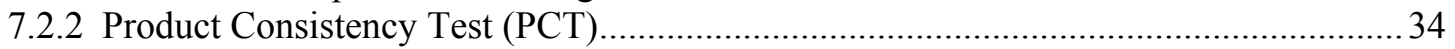

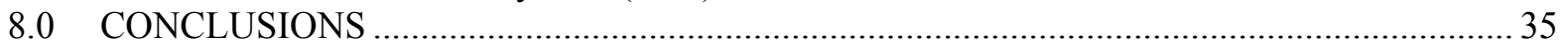

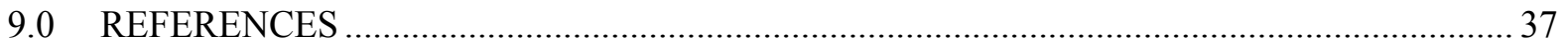

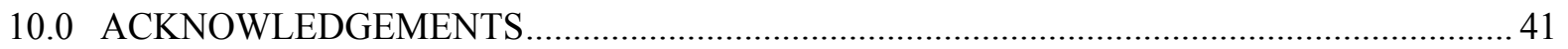

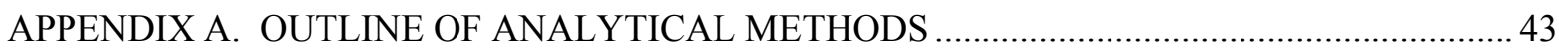

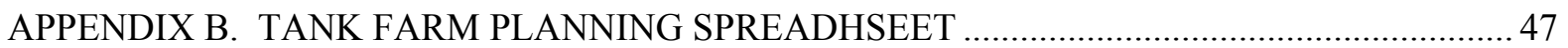

APPENDIX C. PU/U/GD AND NP STREAMS USED IN SRTC SLUDGE BATCH 3

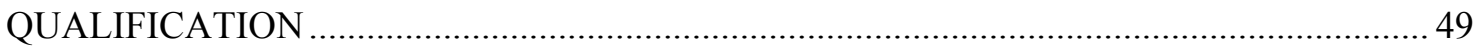

APPENDIX D. ACID CALCULATION SPREADSHEET FOR THE SECOND SRAT CYCLE .... 53 APPENDIX E. DESCRIPTION AND RESULTS OF THE FIRST SRAT CYCLE USING SB3

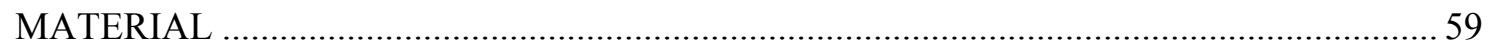

APPENDIX F. COMPARISON OF RADIOACTIVE AND SIMULANT SRAT/SME TESTING .. 65

APPENDIX G. MASS BALANCE AND ANION DESTRUCTION CALCULATIONS ................. 75 


\section{LIST OF FIGURES}

Figure 4-1. Photograph of 1-L SRAT/SME Vessel in SRTC Shielded Cells Mockup Area .............. 13

Figure 4-2 Gas Generation During the Second SRTC SRAT Cycle ................................................... 20

Figure 5-1. SME Cycle Gas Generation Rates ............................................................................ 26

Figure 6-1. Hydrogen Generation Rate After the Addition of 45 Gallons (DWPF Scale) of 90wt\% Formic Acid to SME Cycle Product................................................................................. 29

Figure 6-2. Hydrogen Generation Rate After the Addition of 235 Gallons (DWPF Scale) of

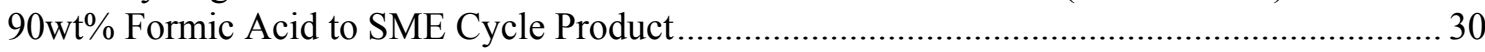

\section{LIST OF TABLES}

Table 2-1. Composition of As-Received Tank 51 Sample.....

Table 3-1. Tank Farm and SRTC Planned Processing of Tank 51 to Obtain Sludge Batch 3 Slurry for Qualification (July 2003)

Table 3-2. Weight Percent Solids and Density of the SRTC Sludge Batch 3 Qualification Sample .... 6

Table 3-3. Elements in the SRTC Sludge Batch 3 Qualification Sample 7

Table 3-4. Major Anions in the SRTC Sludge Batch 3 Qualification Sample Supernate ..................... 8

Table 3-5. Anions, Base Equivalents, and TIC/TOC Results of the SRTC Sludge Batch 3 Qualification Sample Slurry ....

Table 3-6. Coal Concentration in the SRTC Sludge Batch 3 Qualification Sample ........................... 9

Table 3-7. Radioactive Results of the SRTC Qualification Sample Slurry.....

Table 3-8. Comparison Between the Tank Farm Predicted and SRTC Measured Sludge Batch 3 Major Ions, Supernate Density, and Weight Percent Insoluble Solids ....................................... 12

Table 4-1. Summary of Inputs for the Acid Calculations of the Second SRTC Shielded Cells

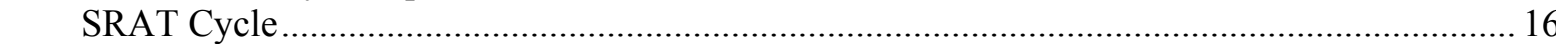

Table 4-2. DWPF and SRTC Scale SRAT Processing Parameters and Acid Addition Amounts....... 17

Table 4-3. Weight Percent Solids and Density of the Second SRTC SRAT Cycle Product Using

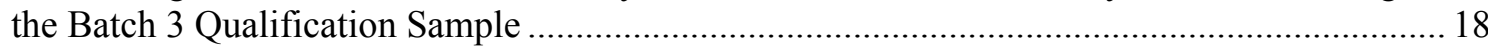

Table 4-4. Elements in the Sludge Batch 3 Second SRTC SRAT Cycle Product Necessary for DWPF Blending Calculations Presented in Units of Weight Percent of Total Dried Solids....... 18

Table 4-5. Measured Anions and Final pH in the Second SRTC SRAT Product .............................. 19

Table 4-6. Maximum Observed DWPF Scale Hydrogen, Carbon Dioxide, and Nitrous Oxide Concentrations and Generation Rates During the Sludge Batch 3 SRAT Cycle in the SRTC Shielded Cells

Table 4-7. SRAT Cycle Nitrite to Nitrate conversion, \% Formate Destruction, and \% Oxalate Destruction and Comparison to Acid Calculation Assumptions ............................................... 20

Table 4-8. Supernate Concentrations and Percent Soluble for Selected Elements in the SRAT

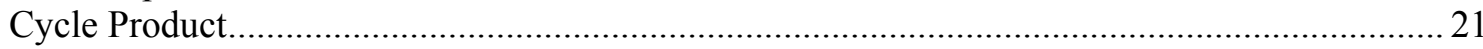

Table 5-1. DWPF and SRTC Scale SME Processing Parameters .................................................. 23

Table 5-2. Weight Percent Solids and Density of the SRTC SME Cycle Product Using the Sludge Batch 3 Qualification Sample

Table 5-3. Measured Anions, Total Organic Carbon, and pH in the SME Cycle Product Slurry ....... 24

Table 5-4. Maximum Observed DWPF Scale Hydrogen, Carbon Dioxide, and Nitrous Oxide Concentration and Generation Rates During the Sludge Batch 3 SME Cycle in the SRTC Shielded Cells 
WSRC-TR-2004-00050

\section{Revision 0}

Table 5-5. Calculated Nitrite Destruction, Nitrite to Nitrate conversion, \% Formate Destruction, and \% Oxalate Destruction and Comparison to Acid Calculation Assumptions .........................26

Table 7-1. Published and Average Measured Values of Analytical Reference Glass-1.................... 32

Table 7-2. Elemental Composition of Glass Fabricated With Sludge Batch 3 Material and Frit 202

Table 7-3. Oxide Composition of Glass Fabricated With Sludge Batch 3 Material and Frit 202 33

Table 7-4. Normalized Mass Releases (Grams Glass/Liter) Based on B, Li, and Na for Sludge Batch 3/Frit 202 Glass and EA Glass in a $90^{\circ} \mathrm{C} \mathrm{PCT}$ 34 


\section{LIST OF ACRONYMS}

$\begin{array}{ll}\text { ACTL } & \text { Aiken County Technology Laboratory } \\ \text { ADS } & \text { Analytical Development Section } \\ \text { ARG } & \text { Analytical Reference Glass } \\ \text { ARM } & \text { Approved Reference Material } \\ \text { ARP } & \text { Actinide Removal Process } \\ \text { ASP } & \text { Analytical Study Plan } \\ \text { ASTM } & \text { American Society of Testing and Materials } \\ \text { CBU } & \text { Closure Business Unit } \\ \text { DI } & \text { de-ionized } \\ \text { DWPF } & \text { Defense Waste Processing Facility } \\ \text { EA } & \text { Environmental Assessment } \\ \text { GC } & \text { gas chromatograph } \\ \text { HTO } & \text { tritiated water } \\ \text { IC } & \text { Ion chromatography } \\ \text { ICP-ES } & \text { Inductively coupled plasma emissions spectroscopy } \\ \text { ICP-MS } & \text { inductively coupled plasma mass spectroscopy } \\ \text { L } & \text { Liter } \\ \text { MST } & \text { Monosodium Titanate } \\ \text { PCT } & \text { Product Consistency Test } \\ \text { PMP } & \text { polymethylpentene } \\ \text { RCRA } & \text { Resource Conservation and Recovery Act } \\ \text { SB3 } & \text { Sludge Batch 3 } \\ \text { scfm } & \text { standard cubic feet per minute } \\ \text { SME } & \text { Slurry Mix Evaporator } \\ \text { SRAT } & \text { Sludge Receipt and Adjustment Tank } \\ \text { SRTC } & \text { Savannah River Technology Center } \\ \text { TGA } & \text { Thermogravimetric analysis } \\ \text { TIC } & \text { Total Inorganic Carbon } \\ \text { TOC } & \text { Total Organic Carbon } \\ \text { TTQAP } & \text { Task Technical and Quality Assurance Plan } \\ \text { TTR } & \text { Technical Task Request } \\ \text { WAPS } & \text { Waste Acceptance Product Specifications } \\ & \end{array}$


WSRC-TR-2004-00050

Revision 0

This page intentionally left blank. 


\subsection{INTRODUCTION AND BACKGROUND}

The Defense Waste Processing Facility (DWPF) has requested that a radioactive demonstration of the next batch of sludge slurry (Sludge Batch 3) be completed in the Shielded Cells Facility of the Savannah River Technology Center (SRTC) ${ }^{1}$. Sludge Batch 3 (SB3) consists of the heel in Tank 51, which included Plutonium $(\mathrm{Pu})$ and Americium/Curium $(\mathrm{Am} / \mathrm{Cm})$ transferred from $\mathrm{H}$ and $\mathrm{F}$ Canyon, respectively; sludge slurry from Tank 7 (including sludge transferred into Tank 7 from Tanks 18 and 19); additional Pu transferred from H Canyon; a Neptunium ( $\mathrm{Np}$ ) transfer also from H Canyon; and the remaining Sludge Batch 2 material in Tank $40^{*}$. Because the current contents of Tank 40 (Sludge Batch 2) have already been qualified, this qualification work did not include the contribution of Tank 40.

The sample for this task was taken from Tank 51 in June 2003. The second set of Pu and the Np transfers did not occur prior to obtaining this sample. Therefore, $\mathrm{Pu}$ and $\mathrm{Np}$ solutions were added to the qualification sample by SRTC personnel in the Shielded Cells. The impact of processing a stream of sludge/Monosodium Titanate (MST) from the Actinide Removal Process (ARP), which will possibly be fed to DWPF during SB3 processing, was not evaluated as part of this task.

The purpose of this report is to document the results of SB3 qualification work at SRTC to satisfy the requirements of Technical Task Request HLW/DWPF/TTR-03-0005, Rev. $1^{1}$. Note that results necessary for qualification have been published previously in table form to facilitate acceptance of SB3 by DWPF.,3 The intent of this report is to give a more detailed account of the SRTC qualification work.

Documented in this report are:

- Preparation of a SB3 slurry using a Tank 51 sample from June 2003

- A demonstration of the DWPF Sludge Receipt and Adjustment Tank (SRAT) cycle using SB3 slurry

- A demonstration of the DWPF Slurry Mix Evaporator (SME) cycle using SRAT product

- Glass fabrication and subsequent chemical durability evaluation using SB3 material

- Evaluation of adding formic acid to the SME cycle product

This work is governed by a Technical Task and Quality Assurance Plan (TTQAP) ${ }^{4}$, and analytical work is governed by an Analytical Study Plan (ASP) ${ }^{5}$.

\footnotetext{
${ }^{*}$ DWPF started processing SB3 in March 2004. Due to equipment problems in Tank 51 and H-Canyon, not all the material in Tank 51 or the Np in $\mathrm{H}-$ Canyon was transferred into SB3. Current plans are to transfer the remaining Np and sludge in April and May 2004, respectively. It should be emphasized that SRTC qualification work was based on Tank 51 contents plus all of the planned Np material; these delays in transfers do not affect the qualification work.
} 
WSRC-TR-2004-00050

Revision 0

This page intentionally left blank. 


\subsection{AS-RECEIVED TANK 51 SAMPLE}

A 5 Liter (L) sample of sludge slurry was taken from Tank 51 in June of 2003. The sample was delivered in a section of pipe with plates welded on each end. Two ports for adding and removing material were added to one end. Once placed in the SRTC Shielded Cells, the sampler was agitated by rolling the container on the cell floor. The sludge slurry was then pumped into a semitransparent bottle. The sludge was allowed to settle overnight. Supernate was then pumped back into the sampler to rinse out any additional material. This sample was the basis for Sludge Batch 3 preparation in the SRTC Shielded Cells (see Section 3.0).

The sample was characterized and results reported earlier ${ }^{6,7,8,9}$. A summary of these results is given in Table 2-1. 
Table 2-1. Composition of As-Received Tank 51 Sample

\begin{tabular}{|c|c|c|c|}
\hline \multicolumn{2}{|r|}{ Supernate } & \multirow[b]{2}{*}{ Density, \% Solids, and $\mathrm{pH}$} & \\
\hline & Concentration $(\mathrm{M})$ & & \\
\hline Free $\mathrm{OH}^{-}$ & 0.261 & Slurry Density $(\mathrm{g} / \mathrm{mL})$ & 1.12 \\
\hline $\mathrm{NO}_{3}^{-}$ & 0.195 & Supernate Density $(\mathrm{g} / \mathrm{mL})$ & 1.06 \\
\hline $\mathrm{NO}_{2}^{-}$ & 0.325 & Wt $\%$ Total Solids & 15.7 \\
\hline $\mathrm{SO}_{4}^{-2}$ & 0.0201 & Wt \% Dissolved Solids ${ }^{a}$ & 7.82 \\
\hline $\mathrm{Cl}^{-}$ & 0.0011 & Wt \% Insoluble Solids & 8.53 \\
\hline $\mathrm{CO}_{3}^{-2}$ & $<0.015$ & Wt $\%$ Soluble Solids ${ }^{\text {a }}$ & 7.15 \\
\hline $\mathrm{PO}_{4}^{-3}$ & 0.0003 & $\mathrm{pH}$ & 13.4 \\
\hline $\mathrm{AlO}_{2}^{-}$ & 0.0492 & & \\
\hline $\mathrm{C}_{2} \mathrm{O}_{4}^{-2}$ & 0.0271 & & \\
\hline $\mathrm{K}^{+}$ & $0.0055 \mathrm{E}$ & & \\
\hline $\mathrm{F}^{-}$ & 0.0160 & & \\
\hline $\mathrm{Na}^{+}$ & 1.23 & & \\
\hline
\end{tabular}

Composition of Total Solids

\begin{tabular}{lcll}
\hline & $\mathrm{Wt} \%$ of Total Solids & & $\mathrm{Wt} \%$ of Total Solids \\
\cline { 2 - 2 } $\mathrm{Al}$ & 5.04 & $\mathrm{Ni}$ & 0.868 \\
$\mathrm{~B}$ & 0.008 & $\mathrm{P}$ & 0.253 \\
$\mathrm{Ba}$ & 0.050 & $\mathrm{~Pb}$ & 0.034 \\
$\mathrm{Ca}$ & 1.07 & $\mathrm{Si}$ & 0.94 \\
$\mathrm{Cd}$ & 0.182 & $\mathrm{Sn}$ & 0.039 \\
$\mathrm{Ce}$ & 0.079 & $\mathrm{Sr}$ & 0.271 \\
$\mathrm{Cr}$ & 0.076 & $\mathrm{Ti}$ & 0.014 \\
$\mathrm{Cu}$ & 0.011 & $\mathrm{U}$ & 5.24 \\
$\mathrm{Fe}$ & 12.0 & $\mathrm{Zn}$ & 0.020 \\
$\mathrm{Gd}$ & 0.035 & $\mathrm{Zr}$ & 0.007 \\
$\mathrm{~K}$ & $<0.610$ & $\mathrm{Hg}$ & 0.024 \\
$\mathrm{La}$ & 0.033 & $\mathrm{Ru}$ & 0.028 \\
$\mathrm{Li}$ & 0.015 & $\mathrm{Rh}$ & 0.0055 \\
$\mathrm{Mg}$ & 1.258 & $\mathrm{Pd}$ & 0.0015 \\
$\mathrm{Mn}$ & 3.52 & $\mathrm{Ag}$ & 0.0093 \\
$\mathrm{Mo}$ & 0.032 & $\mathrm{Coal}$ & $0.004-0.07$ \\
$\mathrm{Na}$ & 18.0 & Oxalate & 1.6 \\
\hline
\end{tabular}

$\mathrm{a} \overline{\mathrm{Wt} \% \text { dissolved solids are soluble solids on a supernate basis and are measured by drying supernate. } \mathrm{Wt} \% \text { soluble }}$ solids are soluble solids on a slurry basis, and are calculated as the difference between total and insoluble solids. 


\subsection{SLUDGE BATCH 3 PREPARATION}

A 5-L sample from Tank 51 was received in June 2003 and characterized by SRTC (see Section 2.0). This sample was received prior to planned decants and additions of plutonium and neptunium streams from H Canyon. Therefore, the Tank 51 sample was decanted and additions were made to match as closely as possible to Tank Farm planned processing to prepare a Sludge Batch 3 qualification sample.

\subsection{APPROACH}

A summary of the Tank Farm planned decants and additions for Sludge Batch 3 preparation and the SRTC scale volumes are given in Table 3-1. A spreadsheet from Tank Farm personnel is presented in Appendix B.

Table 3-1. Tank Farm and SRTC Planned Processing of Tank 51 to Obtain Sludge Batch 3 Slurry for Qualification (July 2003)

\begin{tabular}{|c|c|c|}
\hline & $\begin{array}{c}\text { Tank Farm } \\
\text { Volume (gal) }\end{array}$ & $\begin{array}{c}\text { SRTC } \\
\text { Volume } \\
(\mathrm{mL})^{\mathrm{a}}\end{array}$ \\
\hline Tk 51 Slurry & $1,023,000$ & 5,000 \\
\hline First Decant & $(251,000)^{\mathrm{b}}$ & $(1,226)$ \\
\hline Tk 51 After First Decant & 772,000 & 3,774 \\
\hline $\mathrm{Pu} / \mathrm{U} / \mathrm{Gd}$ Solution Addition & 18,660 & 92 \\
\hline Flush and CST Water Addition ${ }^{c}$ & 5,648 & 28 \\
\hline \multicolumn{3}{|c|}{ Tank 51 After Pu/U/Gd Solution, Flush, and } \\
\hline CST Water Additions & 796,000 & 3,894 \\
\hline Second Decant & $(334,000)$ & $(1,637)$ \\
\hline Tk 51 After Second Decant & 462,000 & 2,257 \\
\hline $\mathrm{NaNO}_{2}$ Addition $^{\mathrm{d}}$ & 24,500 & 116 \\
\hline TK 51 After $\mathrm{NaNO}_{2}$ Addition & 486,000 & 2,373 \\
\hline Tk 51 to Tk 40 Transfer $^{\mathrm{e}}$ & 451,000 & 2,373 \\
\hline Np Addition & 13,600 & 69 \\
\hline Add Flush Water ${ }^{c}$ & 5,000 & 27 \\
\hline Sludge Batch 3 for Qualification & 470,000 & 2,469 \\
\hline
\end{tabular}

a SRTC volumes were calculated by a simple ratio with Tank Farm volumes with the exception of sodium nitrite. Sodium nitrite amount was calculated to give a final nitrite to nitrate ratio of 1.66 .

${ }^{\mathrm{b}}$ Actual amount decanted. Planned amount was 449,800 gallons.

${ }^{c}$ It was assumed that the flush water had the same $\mathrm{OH}^{-}$as its respective canyon stream, i.e., flush for the Pu steam was $0.3 \mathrm{M} \mathrm{OH}^{-}$, and flush for the Np stream was $1.2 \mathrm{M} \mathrm{OH}^{-}$.

${ }^{\mathrm{d}}$ The sodium nitrite concentration was $40 \mathrm{wt} \%$.

${ }^{\mathrm{e}}$ For Tank Farm determining SB3 composition, it was assumed that 10 inches of sludge slurry would remain in Tank 51, and that Tank 40 was empty prior to the transfer.

The SRTC SB3 qualification sample was prepared per Table 3-1. Descriptions and compositions of the $\mathrm{Pu} / \mathrm{U} / \mathrm{Gd}$ and $\mathrm{Np}$ streams can be found in Appendix C.

After completion of the decants and additions, the SB3 qualification sample (SRAT Feed/Receipt) was then characterized for comparison to Tank Farm predicted composition and in preparation for a SRAT cycle. The various analyses of the sample are listed below. A brief description of each analysis is given in Appendix A. 


\section{Revision 0}

- Density of slurry and supernate

- Weight percent solids of slurry and supernate

- Anion analysis of supernate

- Elemental analysis of supernate

- Elemental analysis of total solids

- Carbonate content of slurry

- Total base of slurry

- Oxalate content of slurry

- Coal content of slurry

Finally, the SRAT Feed/Receipt was given a preliminary rheological analysis using an RV-30 rheometer in the Shielded Cells.

\subsection{RESULTS}

Analytical results of the SRTC SB3 qualification sample are given below in Table 3-2 through Table 3-7.

Table 3-2 shows the weight percent solids and density measurements of the qualification sample. Measurements of weight percent total and dissolved solids and slurry and supernate densities were performed in quadruplicate. The small relative standard deviations show the measurements had good repeatability. In comparing these results to Sludge Batch 2, the major difference is in the total and dissolved solids. This is expected since SB3 was not washed to lower sodium concentrations as was done for SB2.

Table 3-2. Weight Percent Solids and Density of the SRTC Sludge Batch 3 Qualification Sample

\begin{tabular}{|c|c|}
\hline $\mathrm{Wt} \%$ and Density & Average (Std. Dev., \%Rel. Std. Dev.) \\
\hline $\mathrm{Wt}^{\mathrm{C}} \%$ Total Solids ${ }^{\mathrm{a}}$ & $27.2(0.16,0.39)$ \\
\hline $\mathrm{Wt}^{\mathrm{O}} \mathrm{\text {DissolvedSolids }}{ }^{\mathrm{b}}$ & $12.1(0.07,0.57)$ \\
\hline $\mathrm{Wt}^{\mathrm{t}} \%$ Soluble Solids ${ }^{\mathrm{c}}$ & $10.1(0.20,2.0)$ \\
\hline $\mathrm{Wt} \%$ Insoluble Solids ${ }^{\mathrm{d}}$ & $17.1(0.18,1.1)$ \\
\hline Slurry Density & $1.22(0.01,1.2)$ \\
\hline Supernate Density & $1.09(0.01,0.7)$ \\
\hline
\end{tabular}

${ }^{\mathrm{a}} \mathrm{Wt} \%$ total solids in slurry (measured).

${ }^{\mathrm{b}} \mathrm{Wt} \%$ solids (dissolved) in supernate (measured).

${ }^{\mathrm{c}} \mathrm{Wt} \%$ soluble solids in slurry (calculated from $\mathrm{Wt} \%$ total and insoluble solids).

${ }^{\mathrm{d}} \mathrm{Wt} \%$ insoluble solids in slurry (calculated from $\mathrm{Wt} \%$ total and dissolved solids).

Table 3-3 presents elements in the SRTC SB3 sample solids. Elements presented are those that are greater than $0.7 \%$ of the total solids, noble metals, Resource Conservation and Recovery Act (RCRA) hazardous elements (e.g., $\mathrm{Cr}$ and $\mathrm{Hg}$ ), and other elements specifically requested by DWPF such as $\mathrm{Cu}, \mathrm{P}$, and Ti. 
Table 3-3. Elements in the SRTC Sludge Batch 3 Qualification Sample

\begin{tabular}{lclc}
\hline & $\begin{array}{c}\text { Wt\% of Total Solids } \\
\text { Element }\end{array}$ & Element & $\begin{array}{c}\text { Wt\% of Total Solids } \\
\text { (Std. Dev., \%Rel. Std. Dev. })\end{array}$ \\
\hline $\mathrm{Al}^{\mathrm{a}}$ & $5.12(0.14,2.8)$ & $\mathrm{Na}^{\mathrm{e}}$ & $14.1(0.56,4.0)$ \\
$\mathrm{As}^{\mathrm{c}}$ & $<0.005(\mathrm{NA})$ & $\mathrm{Ni}^{\mathrm{a}}$ & $0.929(0.051,5.5)$ \\
$\mathrm{B}^{\mathrm{b}}$ & $<1.5(\mathrm{NA})$ & $\mathrm{P}^{\mathrm{a}}$ & $<0.5(\mathrm{NA})$ \\
$\mathrm{Ba}^{\mathrm{a}}$ & $0.0463(0.0027,5.8)$ & $\mathrm{Pb}^{\mathrm{a}}$ & $<0.3(\mathrm{NA})$ \\
$\mathrm{Be}^{\mathrm{e}}$ & $<5 \mathrm{E}-04(\mathrm{NA}))$ & $\mathrm{Sb}^{\mathrm{a}}$ & $<0.2(\mathrm{NA})$ \\
$\mathrm{Ca}^{\mathrm{a}}$ & $1.28(0.084,6.6)$ & $\mathrm{Se}^{\mathrm{c}}$ & $<0.00414(\mathrm{NA})$ \\
$\mathrm{Cd}^{\mathrm{a}}$ & $0.212(0.007 .4,3.5)$ & $\mathrm{Si}^{\mathrm{b}}$ & $1.07(0.015,1.4)$ \\
$\mathrm{Cr}^{\mathrm{a}}$ & $0.0892(0.017,19)$ & $\mathrm{Ti}^{\mathrm{a}}$ & $0.0137(0.0011,7.9)$ \\
$\mathrm{Cu}^{\mathrm{a}}$ & $<2.92 \mathrm{E}-02(\mathrm{NA})$ & $\mathrm{U}^{\mathrm{a}}$ & $5.71(0.17,3.0)$ \\
$\mathrm{Fe}^{\mathrm{a}}$ & $13.8(0.60,4.4)$ & $\mathrm{Ag}^{\mathrm{d}}$ & $0.0115(4.2 \mathrm{E}-04,7.4)$ \\
$\mathrm{Hg}^{\mathrm{c}}$ & $0.0654(0.0027,4.2)$ & $\mathrm{Pd}^{\mathrm{d}}$ & $0.00166(3.9 \mathrm{E}-04,6.4)$ \\
$\mathrm{K}^{\mathrm{c}}$ & $6.35 \mathrm{E}-02(0.0072,11)$ & $\mathrm{Rh}^{\mathrm{d}}$ & $0.00712(4.5 \mathrm{E}-04,6.3)$ \\
$\mathrm{Mg}^{\mathrm{a}}$ & $1.45(0.059,4.0)$ & $\mathrm{Ru}^{\mathrm{d}}$ & $0.0362(9.8 \mathrm{E}-04,7.5)$ \\
$\mathrm{Mn}^{\mathrm{a}}$ & $3.98(0.16,4.0)$ & & \\
\hline
\end{tabular}

${ }^{a}$ Average of eight measurements by ICP-ES (four aqua regia digestions and four peroxide fusion digestions).

${ }^{\mathrm{b}}$ Average of four measurements by ICP-ES (from peroxide fusion digestions).

${ }^{\mathrm{c}}$ Average of four measurements by AA (from aqua regia digestions).

${ }^{\mathrm{d}}$ Results are determined by ICP-MS and are the averages of the results of four samples of dissolved dried slurry.

${ }^{\mathrm{e}}$ Average of four measurements by ICP-ES (from aqua regia digestions).

Table 3-4 shows the major components of the SB3 sample supernate. Sodium is the only metal reported in the table; all other metals had concentrations less than $0.05 \mathrm{M}$. In evaluating these results, the accuracy of the free hydroxide value is questionable. Based on the initial Tank 51 sample, the free hydroxide should be approximately $0.26 \mathrm{M}$. The relative standard deviation of the measurement is also high. However, for acid calculations and SRAT processing, this result is not used, and the questionable accuracy does not impact SRAT processing. 


\section{Revision 0}

Table 3-4. Major Anions in the SRTC Sludge Batch 3 Qualification Sample Supernate

\begin{tabular}{|c|c|}
\hline & $\begin{array}{c}\text { Average } \\
\text { (Std. Dev., \%Rel. Std. Dev.) }\end{array}$ \\
\hline Nitrite $(\mathrm{M})^{\mathrm{a}}$ & $0.722(0.057,7.8)$ \\
\hline Nitrate $(M)^{a}$ & $0.416(0.020,4.9)$ \\
\hline Chloride $(\mathrm{M})^{\mathrm{a}}$ & $<0.004$ (NA) \\
\hline Fluoride $(\mathrm{M})^{\mathrm{a}}$ & $0.0130(0.00090,6.9)$ \\
\hline Formate $(\mathrm{M})^{\mathrm{a}}$ & $<0.014(\mathrm{NA})$ \\
\hline Oxalate $(\mathrm{M})^{\mathrm{a}}$ & $0.0263(0.0014,5.2)$ \\
\hline Phosphate (M) ${ }^{\mathrm{a}}$ & $<0.007$ (NA) \\
\hline Sulfate (M) ${ }^{\mathrm{a}}$ & $0.0485(0.0029,5.9)$ \\
\hline Carbonate $(\mathrm{M})^{\mathrm{b}}$ & $0.0342(0.00094,2.8)$ \\
\hline Hydroxide (M) ${ }^{c}$ & $0.174(0.045,26)$ \\
\hline Sodium $(M)^{d}$ & $1.80(0.067,3.7)$ \\
\hline \multicolumn{2}{|c|}{$\begin{array}{l}\text { NA = Not Applicable } \\
\text { a } \text { Ion Chromatography (IC) analysis of supernate } \\
\text { b Determined by precipitation of insoluble barium carbonate and then } \\
\text { carbonate concentration is determined via back titration with } \mathrm{HCl} \\
{ }^{c} \text { Determined from titration of supernate } \\
\text { d Determined by ICP-ES analysis of acidified supernate }\end{array}$} \\
\hline
\end{tabular}

Table 3-5 lists anions, total carbon, and base equivalent results of the SB3 sample on a slurry basis. Hydroxide and carbonate are not reported in this table. These anions contribute to the total base of the sludge slurry, and are captured in the titration to determine base equivalents. Slurry concentrations of soluble species (nitrite, nitrate, chloride, fluoride, formate, and phosphate) were calculated based on supernate analyses using the following equation:

$$
C_{i}=\frac{M_{i} \cdot M W_{i}}{D_{\text {supn }}} \cdot \frac{W_{S S}}{W_{d s}} \cdot 1000
$$

where,

$\mathrm{C}_{\mathrm{i}}$ is the concentration of $\mathrm{i}$ in the slurry $(\mathrm{mg} / \mathrm{kg})$

$\mathrm{M}_{\mathrm{i}}$ is the molarity of $\mathrm{i}$ in the supernate $(\mathrm{mol} / \mathrm{L})$

$\mathrm{MW}_{\mathrm{i}}$ is the molecular weight of $\mathrm{i}(\mathrm{g} / \mathrm{mol})$

$\mathrm{W}_{\mathrm{ds}}$ is the weight percent dissolved solids in the supernate

$\mathrm{W}_{\mathrm{ss}}$ is the weight percent soluble solids in the slurry

$\mathrm{D}_{\text {supn }}$ is the density of the supernate $(\mathrm{kg} / \mathrm{L})$

1000 is the conversion from $\mathrm{g}$ to $\mathrm{mg}$.

Sulfate presented in Table 3-5 is also calculated from the soluble sulfate measured in the supernate (see above equation). It is assumed that all of the sulfate is soluble ${ }^{10}$. Oxalate and total carbon (Total Inorganic Carbon (TIC) and Total Organic Carbon (TOC)) were determined from slurry samples, and no conversion is necessary. 
Table 3-5. Anions, Base Equivalents, and TIC/TOC Results of the SRTC Sludge Batch 3 Qualification Sample Slurry

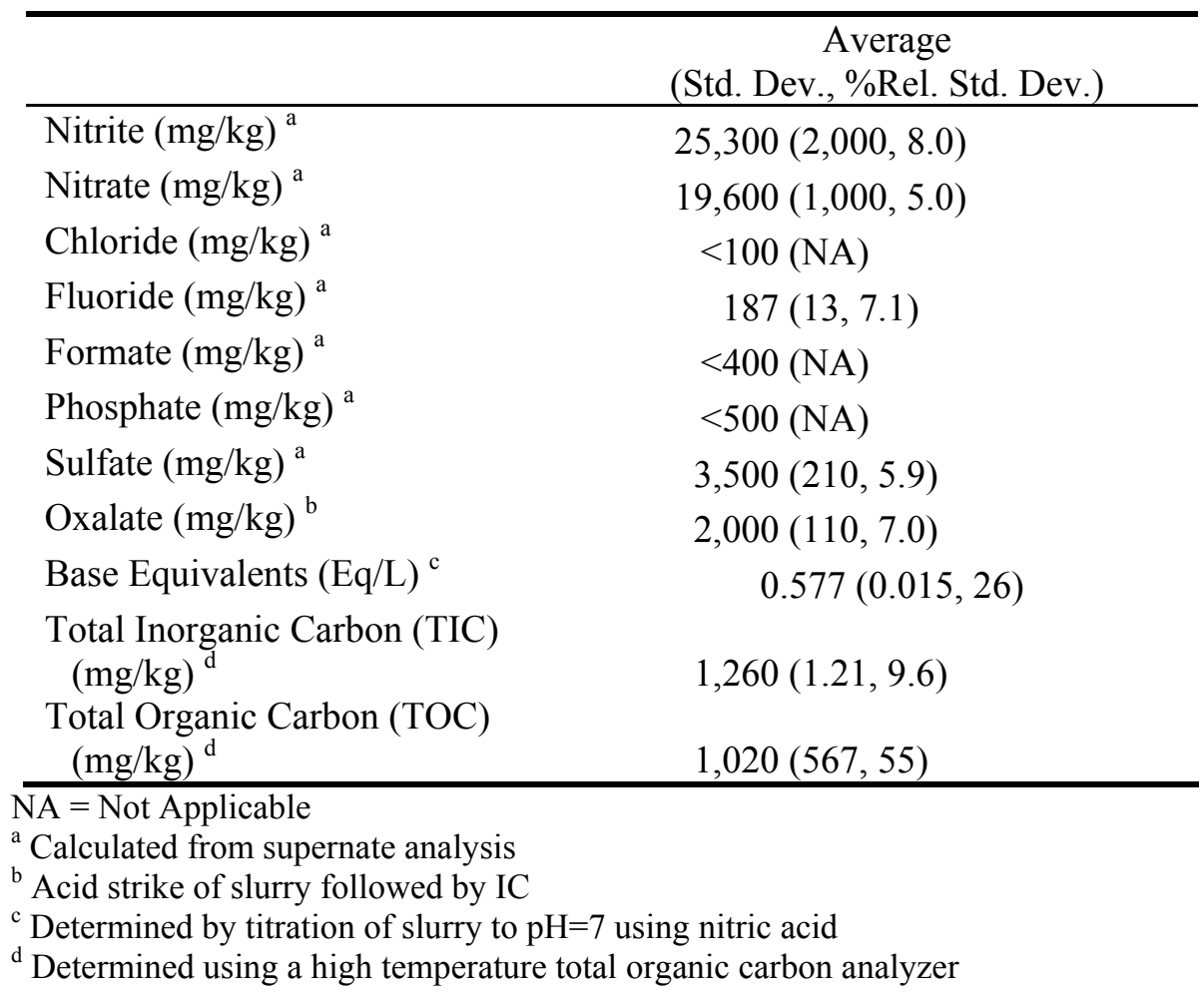

Table 3-6 lists coal concentrations on both a total solids and a slurry basis. Concentrations were determined by thermogravimetric analysis (TGA), basically weight loss as a function of temperature. The maximum concentration is based on a total weight loss of filtered washed solids. The minimum concentration is based on weight loss of the solids in the temperature range of coal oxidation. The large difference between minimum and maximum values is caused by other species volatilized in the TGA.

Table 3-6. Coal Concentration in the SRTC Sludge Batch 3 Qualification Sample

\begin{tabular}{|c|c|c|}
\hline & $\begin{array}{c}\text { Minimum }^{\text {a }} \\
\text { (Std. Dev., \%Rel. Std. } \\
\text { Dev.) }\end{array}$ & $\begin{array}{c}\text { Maximum }^{\text {a }} \\
\text { (Std. Dev., \%Rel. Std. } \\
\text { Dev.) }\end{array}$ \\
\hline $\begin{array}{l}\text { As wt } \% \text { of Total Solids } \\
\text { As mg/kg slurry (ppm) }\end{array}$ & $\begin{array}{c}0.00393(0.0027,70) \\
11\end{array}$ & $\begin{array}{c}0.119(0.027,22) \\
324\end{array}$ \\
\hline
\end{tabular}

Table 3-7 presents the measured or estimated concentrations for thirty radionuclides, the measured value for the total beta activity, and the calculated values for the total alpha and total gamma activities. The concentration of those radionuclides that could not be measured due to their low concentrations is estimated from minimum detection limits based on the analytical method used. For all the radionuclides except tritium $\left(\mathrm{T}\right.$ or ${ }^{3} \mathrm{H}$ ), the concentrations given in Columns 2 and 3 of Table 3-7 are based on weight percent in the total solids of the dried sludge slurry and microcuries $(\mu \mathrm{Ci})$ per gram of dried sludge slurry. Columns 4 and 5 present the standard deviations based on four replicates and the percent relative standard 


\section{WSRC-TR-2004-00050 \\ Revision 0}

deviation (\%RSD). Tritium in the slurry is present predominantly as tritiated water (HTO). Consequently its concentration in the dried solids could not be determined because the HTO was evaporated during the drying of the slurry. The concentration of tritium was determined by counting the beta particles from HTO that were steam stripped from three aliquots of the supernate of the slurry. This supernate probably contains most if not all the ${ }^{3} \mathrm{H}$. The ${ }^{3} \mathrm{H}$ concentration in the slurry was then calculated based on the density of the slurry and supernate and weight percent insoluble and total solids in the slurry. The \%RSD for the ${ }^{3} \mathrm{H}$ measurements is presented in Column 5 for that radionuclide and is based on three measurements. The last column in the Table presents Curie concentrations in the sludge slurry in units of Curies per gallon of slurry. These concentrations are based on the weight percent total solids and on the measured densities of the sludge slurry and the slurry supernate for the SB3 Qualification Sample. These values are $27.2 \mathrm{wt}$ \% total solids, $17.1 \mathrm{wt} . \%$ insoluble solids, 1.22 grams per milliliter for the density of the slurry, and 1.09 grams per milliliter for the density of the supernate (see Table 3-2). These quantities for the actual slurry that the DWPF will receive in SB3 will be determined at SRTC using a slurry sample from Tank 40 after the transfer of the material in Tank 51 to Tank 40 is done to complete formation of SB3.

The concentrations and upper limits in Table 3-7 are based on four replicate samples (except for H-3 where only three samples were used). Concentrations of ${ }^{3} \mathrm{H},{ }^{60} \mathrm{Co},{ }^{90} \mathrm{Sr},{ }^{137} \mathrm{Cs},{ }^{154} \mathrm{Eu},{ }^{155} \mathrm{Eu},{ }^{241} \mathrm{Pu},{ }^{238} \mathrm{Pu}$, and ${ }^{241} \mathrm{Am}$, along with total beta activity are based on analyses by radioactive counting techniques. The results for ${ }^{99} \mathrm{Tc},{ }^{233} \mathrm{U},{ }^{234} \mathrm{U},{ }^{235} \mathrm{U},{ }^{237} \mathrm{~Np},{ }^{238} \mathrm{U},{ }^{239} \mathrm{Pu},{ }^{240} \mathrm{Pu},{ }^{244} \mathrm{Cm}$, and ${ }^{245} \mathrm{Cm}$ were determined by Inductively Coupled Plasma Mass Spectroscopy (ICP-MS). The concentrations of radionuclides ${ }^{106} \mathrm{Ru}$, ${ }^{125} \mathrm{Sb},{ }^{125 \mathrm{~m}} \mathrm{Te},{ }^{134} \mathrm{Cs},{ }^{144} \mathrm{Ce}$, and ${ }^{147} \mathrm{Pm}$ have upper limits reported due to their concentrations being too low to be detected because of their short half-lives and the age of the sludge. The radionuclides ${ }^{90} \mathrm{Y},{ }^{125 \mathrm{~m}} \mathrm{Te}$, and ${ }^{137 \mathrm{~m}} \mathrm{Ba}$ are in secular equilibrium with their respective parent radionuclides. Thus the Curie concentrations of ${ }^{90} \mathrm{Y}$ and ${ }^{125 \mathrm{~m}} \mathrm{Te}$ are equal to that of their parents. Approximately $5 \%$ of the ${ }^{137} \mathrm{Cs}$ decays directly to stable ${ }^{137} \mathrm{Ba}$; thus the Curie concentration of ${ }^{137 \mathrm{~m}} \mathrm{Ba}$ is $95 \%$ of the Curie concentration of ${ }^{137} \mathrm{Cs}$. The upper limits for ${ }^{106} \mathrm{Ru},{ }^{125} \mathrm{Sb},{ }^{125 \mathrm{~m}} \mathrm{Te},{ }^{134} \mathrm{Cs}$, and ${ }^{144} \mathrm{Ce}$ are based on measured gamma counting detection limits. The radionuclide ${ }^{147} \mathrm{Pm}$ is a short lived $\left(\mathrm{t}_{1 / 2}=2.6\right.$ years $)$ beta emitter that could not be detected by gamma counting. An upper limit for its beta activity was estimated from the total beta activity measured in the sample corrected for the beta activities measured for the beta emitting radionuclides that could be measured. The upper limits for ${ }^{14} \mathrm{C}$ and ${ }^{129} \mathrm{I}$ are projections from their concentrations in Sludge Batch 2 (SB2) ${ }^{11}$ and the concentrations given in the Westinghouse Savannah River Company Concentrate, Transfer, and Storage Characterization Database ${ }^{12}$. This is the method agreed upon in the Technical Task Request (TTR) ${ }^{1}$ to estimate these concentrations. Finally, the concentration of ${ }^{242 \mathrm{~m}} \mathrm{Am}$ was estimated using the ratio of its concentration to that of ${ }^{244} \mathrm{Cm}$ in $\mathrm{SB} 2$ and the measured concentration of ${ }^{244} \mathrm{Cm}$ in the Tank $51 \mathrm{SB} 3$ Qualification Sample. The ${ }^{242 \mathrm{~m}} \mathrm{Am}$ concentration is given in the table as an upper limit because only an upper limit could be measured in SB2.

Determination of the concentration of ${ }^{242 \mathrm{~m}} \mathrm{Am}$ along with the concentrations of ${ }^{14} \mathrm{C},{ }^{129} \mathrm{I}$, and ${ }^{147} \mathrm{Pm}$ require special separation techniques in order to determine the exact values or to get better estimates of their upper limits. Until these techniques are applied to the final SB3 material, the upper limits for ${ }^{14} \mathrm{C},{ }^{129} \mathrm{I}$, ${ }^{147} \mathrm{Pm}$, and ${ }^{242 \mathrm{~m}} \mathrm{Am}$ presented in Table 3-2 are recommended for use by the DWPF. 
Table 3-7. Radioactive Results of the SRTC Qualification Sample Slurry

\begin{tabular}{|c|c|c|c|c|c|}
\hline Radionuclide & $\begin{array}{c}\text { Weight } \% \text { in } \\
\text { Total Dried } \\
\text { Solids of the } \\
\text { Slurry }\end{array}$ & $\begin{array}{c}\mu \mathrm{Ci} / \mathrm{g} \text { in Total } \\
\text { Dried Solids } \\
\text { of the Slurry }\end{array}$ & $\begin{array}{l}\text { Std. Dev. } \\
\text { Based on } \\
(\mu \mathrm{Ci} / \mathrm{g}) \\
\text { Results }\end{array}$ & $\%$ RSD & $\begin{array}{l}\mathrm{Ci} / \text { gal in Sludge } \\
\text { Slurry based on } \\
\text { measured wt\% } \\
\text { solids in SRTC } \\
\text { SB3 Qual' Spl' a }\end{array}$ \\
\hline${ }^{3} \mathrm{H}$ & $\mathrm{b}$ & $\mathrm{b}$ & $\mathrm{N} / \mathrm{A}$ & $3.5^{b}$ & $2.2 \mathrm{E}-05^{\mathrm{b}}$ \\
\hline${ }^{14} \mathrm{C}$ & $<7.6 \mathrm{E}-08$ & $<3.4 \mathrm{E}-03$ & $\mathrm{~N} / \mathrm{A}$ & $\mathrm{N} / \mathrm{A}$ & $<4.3 \mathrm{E}-06$ \\
\hline${ }^{60} \mathrm{Co}$ & $9.3 \mathrm{E}-08$ & $1.1 \mathrm{E}+00$ & $6.9 \mathrm{E}-02$ & $6.3 \mathrm{E}+00$ & $1.3 \mathrm{E}-03$ \\
\hline${ }^{90} \mathrm{Sr}$ & $3.4 \mathrm{E}-03$ & $4.6 \mathrm{E}+03$ & $6.0 \mathrm{E}+02$ & $1.3 \mathrm{E}+01$ & $5.8 \mathrm{E}+00$ \\
\hline${ }^{90} \mathrm{Y}$ & $8.5 \mathrm{E}-07$ & $4.6 \mathrm{E}+03$ & $6.0 \mathrm{E}+02$ & $1.3 \mathrm{E}+01$ & $5.8 \mathrm{E}+00$ \\
\hline${ }^{99} \mathrm{Tc}$ & $1.2 \mathrm{E}-03$ & $2.0 \mathrm{E}-01$ & $9.3 \mathrm{E}-03$ & $4.8 \mathrm{E}+00$ & $2.5 \mathrm{E}-04$ \\
\hline${ }^{106} \mathrm{Ru}{ }^{\mathrm{c}}$ & $<7.4 \mathrm{E}-09$ & $<2.5 \mathrm{E}-01$ & $\mathrm{~N} / \mathrm{A}$ & $\mathrm{N} / \mathrm{A}$ & $<3.1 \mathrm{E}-04$ \\
\hline${ }^{125} \mathrm{Sb}$ & $<7.8 \mathrm{E}-09$ & $<8.0 \mathrm{E}-02$ & $\mathrm{~N} / \mathrm{A}$ & $\mathrm{N} / \mathrm{A}$ & $<1.0 \mathrm{E}-04$ \\
\hline${ }^{125 \mathrm{~m}} \mathrm{Te}$ & $<4.4 \mathrm{E}-10$ & $<8.0 \mathrm{E}-02$ & $\mathrm{~N} / \mathrm{A}$ & $\mathrm{N} / \mathrm{A}$ & $<1.0 \mathrm{E}-04$ \\
\hline${ }^{129} \mathrm{I}$ & $<1.6 \mathrm{E}-06$ & $<2.8 \mathrm{E}-06$ & $\mathrm{~N} / \mathrm{A}$ & $\mathrm{N} / \mathrm{A}$ & $<3.5 \mathrm{E}-09$ \\
\hline${ }^{134} \mathrm{Cs}$ & $<4.3 \mathrm{E}-08$ & $<5.5 \mathrm{E}-01$ & $\mathrm{~N} / \mathrm{A}$ & $\mathrm{N} / \mathrm{A}$ & $<7.0 \mathrm{E}-04$ \\
\hline${ }^{137} \mathrm{Cs}$ & $4.3 \mathrm{E}-04$ & $3.8 \mathrm{E}+02$ & $8.0 \mathrm{E}+00$ & $2.2 \mathrm{E}+00$ & 4.7E-01 \\
\hline${ }^{137 m} \mathrm{Ba}$ & $6.7 \mathrm{E}-11$ & $3.6 \mathrm{E}+02$ & $7.6 \mathrm{E}+00$ & $2.1 \mathrm{E}+00$ & $4.5 \mathrm{E}-01$ \\
\hline${ }^{144} \mathrm{Ce}^{\mathrm{c}}$ & $<1.1 \mathrm{E}-08$ & $<3.6 \mathrm{E}-01$ & N/A & $\mathrm{N} / \mathrm{A}$ & $<4.5 \mathrm{E}-04$ \\
\hline${ }^{147} \mathrm{Pm}$ & $<4.1 \mathrm{E}-04$ & $<3.8 \mathrm{E}+03$ & $\mathrm{~N} / \mathrm{A}$ & $\mathrm{N} / \mathrm{A}$ & $<4.8 \mathrm{E}+00$ \\
\hline${ }^{154} \mathrm{Eu}$ & $3.7 \mathrm{E}-06$ & $9.9 \mathrm{E}+00$ & $6.9 \mathrm{E}-01$ & $6.9 \mathrm{E}+00$ & $1.2 \mathrm{E}-02$ \\
\hline${ }^{155} \mathrm{Eu}$ & $3.9 \mathrm{E}-07$ & $1.8 \mathrm{E}+00$ & $1.3 \mathrm{E}-01$ & $7.2 \mathrm{E}+00$ & $2.3 \mathrm{E}-03$ \\
\hline${ }^{233} \mathrm{U}$ & $6.7 \mathrm{E}-05$ & $6.5 \mathrm{E}-03$ & $2.0 \mathrm{E}-04$ & $3.0 \mathrm{E}+00$ & 8.3E-06 \\
\hline${ }^{234} \mathrm{U}$ & $3.7 \mathrm{E}-04$ & $2.3 \mathrm{E}-02$ & $1.1 \mathrm{E}-03$ & $4.6 \mathrm{E}+00$ & $2.9 \mathrm{E}-05$ \\
\hline${ }^{235} \mathrm{U}$ & $3.6 \mathrm{E}-02$ & $7.8 \mathrm{E}-04$ & $3.3 \mathrm{E}-05$ & $4.3 \mathrm{E}+00$ & $9.8 \mathrm{E}-07$ \\
\hline${ }^{237} \mathrm{~Np}$ & 8.9E-03 & $6.2 \mathrm{E}-02$ & $2.0 \mathrm{E}-03$ & $3.1 \mathrm{E}+00$ & $7.8 \mathrm{E}-05$ \\
\hline${ }^{238} \mathrm{U}$ & $5.7 \mathrm{E}+00$ & $1.9 \mathrm{E}-02$ & $5.7 \mathrm{E}-04$ & $3.0 \mathrm{E}+00$ & $2.4 \mathrm{E}-05$ \\
\hline${ }^{238} \mathrm{Pu}$ & $1.4 \mathrm{E}-04$ & $2.4 \mathrm{E}+01$ & $1.4 \mathrm{E}+00$ & $5.8 \mathrm{E}+00$ & $3.0 \mathrm{E}-02$ \\
\hline${ }^{239} \mathrm{Pu}$ & $2.3 \mathrm{E}-02$ & $1.5 \mathrm{E}+01$ & $4.5 \mathrm{E}-01$ & $3.1 \mathrm{E}+00$ & $1.8 \mathrm{E}-02$ \\
\hline${ }^{240} \mathrm{Pu}$ & $2.1 \mathrm{E}-03$ & $4.8 \mathrm{E}+00$ & $2.0 \mathrm{E}-01$ & $4.2 \mathrm{E}+00$ & $6.0 \mathrm{E}-03$ \\
\hline${ }^{241} \mathrm{Pu}$ & $7.1 \mathrm{E}-05$ & $7.3 \mathrm{E}+01$ & $6.8 \mathrm{E}+00$ & $9.4 \mathrm{E}+00$ & $9.1 \mathrm{E}-02$ \\
\hline${ }^{241} \mathrm{Am}$ & $3.7 \mathrm{E}-04$ & $1.3 \mathrm{E}+01$ & $9.2 \mathrm{E}-01$ & $7.2 \mathrm{E}+00$ & $1.6 \mathrm{E}-02$ \\
\hline${ }^{242 \mathrm{~m}} \mathrm{Am}$ & $<4.2 \mathrm{E}-06$ & $<4.0 \mathrm{E}-01$ & NA & NA & $<5.1 \mathrm{E}-04$ \\
\hline${ }^{244} \mathrm{Cm}$ & $2.0 \mathrm{E}-04$ & $1.6 \mathrm{E}+02$ & $9.8 \mathrm{E}+00$ & $6.1 \mathrm{E}+00$ & $2.0 \mathrm{E}-01$ \\
\hline${ }^{245} \mathrm{Cm}$ & $1.2 \mathrm{E}-05$ & $2.1 \mathrm{E}-02$ & $2.4 \mathrm{E}-03$ & $1.1 \mathrm{E}+01$ & 2.7E-05 \\
\hline Total alpha & N/A & $2.9 \mathrm{E}+02$ & N/A & $\mathrm{N} / \mathrm{A}$ & $3.6 \mathrm{E}-01$ \\
\hline Total beta & $\mathrm{N} / \mathrm{A}$ & $1.4 \mathrm{E}+04$ & $2.7 \mathrm{E}+02$ & $1.9 \mathrm{E}+00$ & $1.7 \mathrm{E}+01$ \\
\hline Total gamma ${ }^{\mathrm{d}}$ & $\mathrm{N} / \mathrm{A}$ & $4.1 \mathrm{E}+02$ & $\mathrm{~N} / \mathrm{A}$ & $\mathrm{N} / \mathrm{A}$ & $5.1 \mathrm{E}-01$ \\
\hline Total beta-gamma & $\mathrm{N} / \mathrm{A}$ & $1.4 \mathrm{E}+04$ & N/A & N/A & $1.7 \mathrm{E}+01$ \\
\hline
\end{tabular}

$\mathrm{N} / \mathrm{A}=$ Not Applicable

${ }^{a}$ Weight percent total solids in slurry is 27.2 grams solids per 100 grams of slurry and density of slurry is $1.22 \mathrm{~g} / \mathrm{mL}$.

${ }^{\mathrm{b}}$ Most of the H-3 in the slurry is present as HTO; thus, drying the slurry sample would drive off most of the H-3. The concentration of H-3 was measured in three samples of the supernate of the Tank 51 SB3 Qual. Sample slurry. The result was $6.2 \mathrm{E}-03 \mu \mathrm{Ci} / \mathrm{ml}$ with a percent RSD of 3.5 . See text for details.

${ }^{\mathrm{c}}$ The total radioactivity in the slurry due to this radionuclide is twice this value because of the radioactive daughter that is in secular equilibrium with this radionuclide and thus also present in the slurry.

${ }^{\mathrm{d}}$ This assumes that each gamma emitter detected by gamma counting gives off only a single gamma ray.

The predicted and measured major ions, supernate density, and insoluble solids were compared (see Table 3-8). Although SRTC measured values were higher than predicted, differences were less than $10 \%$. Therefore, with CBU concurrence, SRTC proceeded with SRAT processing. 
WSRC-TR-2004-00050

Revision 0

Table 3-8. Comparison Between the Tank Farm Predicted and SRTC Measured Sludge Batch 3 Major Ions, Supernate Density, and Weight Percent Insoluble Solids

\begin{tabular}{lccc}
\hline & $\begin{array}{c}\text { Tank Farm } \\
\text { Predicted }\end{array}$ & SRTC Measured & \\
& 1.75 & 1.80 & +2.9 \\
$\mathrm{Na}^{+}(\mathrm{M})$ & 0.68 & 0.72 & +5.9 \\
$\mathrm{NO}_{2}^{-}(\mathrm{M})$ & 0.41 & 0.42 & +2.4 \\
$\mathrm{NO}_{3}^{-}(\mathrm{M})$ & 1.08 & 1.09 & +0.9 \\
Supernate Density & 16.1 & 17.1 & +6.2 \\
\hline Wt\% Insoluble Solids & Th
\end{tabular}

Rheological measurements of the SB3 SRAT feed were made. Evaluation of the results shows the sample was considerably less viscous than either the Sludge Batch 2 qualification sample or the 2003 Sludge Batch 2 Tank 40 sample $^{13}$. The complete rheological data are published in Reference 14. 


\subsection{SRAT CYCLE}

Two SRAT cycles were completed during qualification. In the first, approximately $1200 \mathrm{~mL}$ of Sludge Batch 3 material was processed. However, equipment problems caused excessive water loss and over concentration of the SRAT contents resulting in abnormal gas generation and questionable anion results (e.g., nitrate and nitrite). Because of the over concentration, a second SRAT cycle was completed using approximately $350 \mathrm{~mL}$ of SB3 material. Product from the first SRAT cycle was used for glass fabrication, since the over concentration would not impact elemental composition, and ultimately glass composition. A description of the first SRAT cycle is given in Appendix E. A description and results of the second, and more prototypic, SRAT cycle is given below.

\subsection{Approach}

\subsubsection{Equipment Description}

The SRAT/SME vessel used in the confirmation run was a glass cylinder approximately 6.75 inches in height and 3.5-3.825 inches in diameter. The SRAT/SME vessel had a capacity of approximately 1 liter. The top of the vessel consisted of a glass lid fitted with a set of ports. These ports were for the installation of supporting equipment, e.g. the agitator, thermocouple, and manometer. The ports were also for process lines, e.g. the primary off-gas line to the SRAT condenser, the air purge inlet, the formic and nitric acid addition lines, and the antifoam addition line (see Figure 4-1 for a photograph of the vessel in the SRTC Shielded Cells Mockup area).

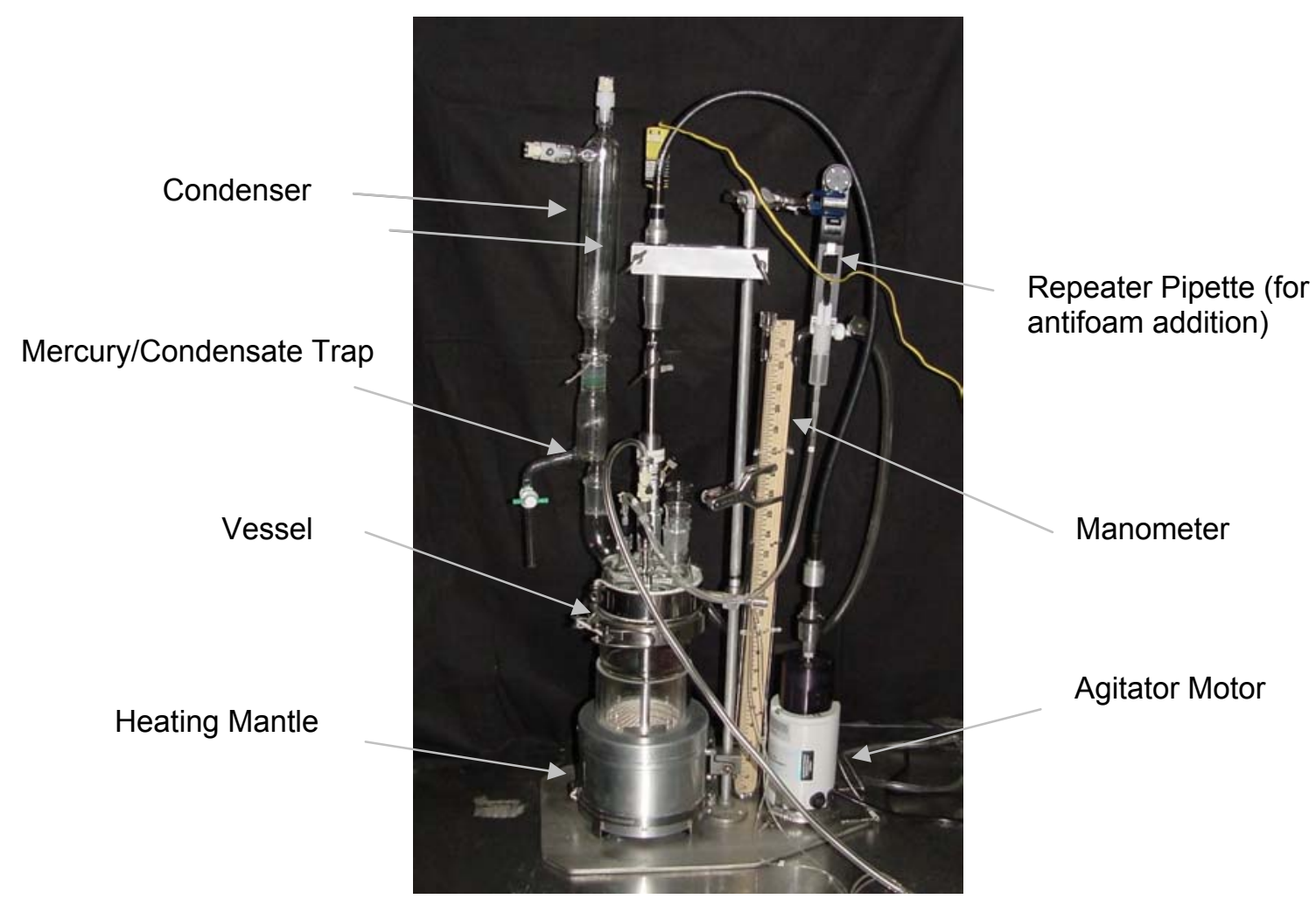

Figure 4-1. Photograph of 1-L SRAT/SME Vessel in SRTC Shielded Cells Mockup Area 


\section{WSRC-TR-2004-00050 \\ Revision 0}

Peripheral equipment was required to perform the SRAT/SME cycle. This included a SRAT condenser. The condenser was cooled using chilled water at $12^{\circ} \mathrm{C}$ supplied within the Cells by a MasterFlex recirculation pump. SRAT Condenser condensate was collected in a mercury/condensate trap. Aqueousphase condensate could either be removed during concentration (dewatering) steps, or it could be refluxed back to the SRAT/SME. Any coalesced elemental mercury would settle into a low point in the collector and not be refluxed.

The heat source to the SRAT/SME was an electric heating mantle that covered the lower 2 inches (180 $\mathrm{ml}$ ) of the vessel. The mantle was controlled by a multipurpose DigiTrol II controller connected to the SRAT thermocouple. This controller was used for both setpoint control, e.g. during acid addition at $93^{\circ} \mathrm{C}$, and for boil-up rate control, i.e., achieving the bench-scale equivalent to 5,000 lbs./hr of boil-up.

The agitator was variable speed and consisted of one flat blade turbine impeller. The agitator was driven by a Stir-pak mixer head attached to a mixer controller. The speed was adjusted until a small vortex was visible on the surface of the slurry.

Acid addition was made using a MasterFlex pump. Separate pump cartridges were used for the nitric acid tubing and for the formic acid tubing. A variable speed controller was used to adjust the flow rate to match the equivalent of 2 gallons per minute.

Air was supplied for purging the SRAT/SME vessel from a compressed gas cylinder containing air mixed with 0.46 volume $\%$ helium. The flow rate was adjusted and controlled using an MKS flow controller. Scaled-DWPF SRAT and SME purge flows were used during the test. The DWPF purge rates were 230 standard cubic feet per minute (scfm) and $74 \mathrm{scfm}$ for the SRAT and SME respectively. The air purge passed through the SRAT vessel and became the carrier for the off-gas flow. Following the SRAT condenser, it passed through a dry ice trap to remove residual moisture. A U-tube manometer was mounted to the SRAT vessel head space to monitor pressure in the vessel.

A portion of the off-gas stream was pulled into a Varian CP-2002 Micro-GC gas chromatograph (GC) for sampling. Column A contains a Molsieve 5A column. It measures helium, hydrogen, oxygen, and nitrogen. Column B contains a PoraPlot Q column. It measures carbon dioxide and nitrous oxide. The GC is located in a radiohood behind the Shielded Cells. Calibration gas is kept near the radiohood, and was used to calibrate the peak areas prior to the SRAT and the SME cycles. It was also used to check the calibrations following both cycles.

\subsubsection{Acid Calculations for the SRAT Cycle}

Analytical data from Section 3.2, along with data presented in this section, were entered into the Immobilization Technology Section acid addition calculation spreadsheet (see Appendix D for a copy of the spreadsheet). The total acid requirement was determined. This was then divided into nitric acid and formic acid using projected anion reaction outcomes and an iron in glass redox target of $0.1 \mathrm{Fe}^{+2} / \Sigma \mathrm{Fe}$.

The nominal concentrations of the nitric and formic acids used for SRAT processing were 50\% and $90 \%$, respectively. Prior to use, the acids were submitted for analyses by titration against a reference base. The as-analyzed results were then used in the acid calculations.

The recommended target for acid in the Shielded Cells SB3 SRAT cycle was $141 \%$ of the calculated stoichiometric requirement ${ }^{15}$. This recommendation was based on nonradioactive simulant testing ${ }^{16}$. The stoichiometric acid calculation was the same as that currently being used in DWPF (function of total equivalent base, inorganic carbon, nitrite, manganese, and mercury in the vessel). The redox equation 
developed for SB3 processing was used instead of the F-3N equation currently in use in DWPF because of small quantities of oxalate and coal reductants that are present in the SB3 waste.

The new redox equation was described in WSRC-TR-2003-00126 (C.M. Jantzen et al.) ${ }^{17}$. It is given by:

$$
\frac{F e^{+2}}{\Sigma F e}=0.1942+0.191 *(2 * F+2 * O+4 * C-5 *(N 1+N 2)-2 * M n) * \frac{45 \%}{w t . \% T S}
$$

where

F formate in SME product, g-mole/kg SME product

$\mathrm{O} \quad$ oxalate in SME product, g-mole $/ \mathrm{kg}$ SME product

$\mathrm{C} \quad$ coal in SME product, g-mole/kg SME product

N1 nitrate in SME product, g-mole $/ \mathrm{kg}$ SME product

N2 nitrite in SME product, g-mole $/ \mathrm{kg} \mathrm{SME} \mathrm{product}$

Mn total manganese in SME product, g-mole/kg SME product

wt. \% TS wt. \% total solids of SME product slurry

A simulant test at $155.5 \%$ of stoichiometry was successful in meeting the processing objectives for SB3, while a second test at $127.9 \%$ met all processing objectives except for nitrite destruction. An assessment of the sensitivity of the delivered acid to the various measurements that form the Shielded Cells acid calculation was available ${ }^{18}$. This indicated that $\sim 9 \%$ errors in acid delivery relative to target occur about $5 \%$ of the time. Therefore a target at $91 \%$ of $155.5 \%$, or $141 \%$, was recommended for the Cells run. This was believed to be sufficiently conservative to ensure that hydrogen generation would remain within the DWPF design basis limits while offering a reasonable chance for also obtaining nitrite destruction to below the DWPF detection limit of approximately $1000 \mathrm{mg} / \mathrm{kg}$ in the SRAT product.

The following additional assumptions were recommended based on simulant testing:

$32.4 \%$ conversion of nitrite ion to nitrate ion

$100 \%$ nitrite ion destruction

$25.2 \%$ formic acid destruction

$57.7 \%$ oxalate ion destruction

$0 \%$ nitrate ion destruction

The acid calculation at $141 \%$ stoichiometry led to an acid requirement of 2.3 moles acid per liter of starting sludge (see Table 4-1). This was more than 2.4 times larger than the acid addition made for the SB2 qualification run at $125 \%$ stoichiometry. SB2 was qualified with only 0.94 moles acid per liter starting sludge. The increased acid requirement for SB3 was driven by two known causes. The base equivalents more than doubled from SB2, and the nitrite ion concentration more than tripled from SB2. 


\section{Revision 0}

Table 4-1. Summary of Inputs for the Acid Calculations of the Second SRTC Shielded Cells SRAT Cycle

\begin{tabular}{|c|c|}
\hline Nitrite $(\mathrm{mg} / \mathrm{kg})$ & 25,300 \\
\hline Nitrate $(\mathrm{mg} / \mathrm{kg})$ & 19,600 \\
\hline Oxalate $(\mathrm{mg} / \mathrm{kg})$ & 2,000 \\
\hline $\mathrm{TIC}(\mathrm{mg} / \mathrm{kg})$ & 1,260 \\
\hline Base Equivalents (moles/L slurry) & 0.577 \\
\hline Mn (wt. \% in dried solids) & 3.99 \\
\hline $\mathrm{Hg}$ (wt. \% in dried solids) & 0.0654 \\
\hline Total Solids (wt. \%) & 27.2 \\
\hline Sludge Density $(\mathrm{g} / \mathrm{ml})$ & 1.22 \\
\hline Assumed Formate Destruction & $25.2 \%$ \\
\hline Assumed Oxalate Destruction & $57.7 \%$ \\
\hline Assumed Nitrite Destruction & $100 \%$ \\
\hline Assumed Nitrite to Nitrate Conversion & $32.4 \%$ \\
\hline Receipt Mass $(\mathrm{g})^{\dagger}$ & 418 \\
\hline Acid Stoichiometry & $141 \%$ \\
\hline Redox Target $\left(\mathrm{Fe}^{+2} / \Sigma \mathrm{Fe}\right)$ & 0.10 \\
\hline Moles of Acid/Liter of Slurry & 2.3 \\
\hline
\end{tabular}

\subsubsection{Description of SRAT Cycle}

The SRAT Cycle was completed per a run plan ${ }^{19}$. A summary of processing parameters and acid addition amounts is presented in Table 4-2. DWPF scale acid amounts are also included for reference and comparison in the table. It should be noted that DWPF will likely not process at the same stoichiometry as SRTC due to factors such as SRAT heel, etc. A summary of the SRAT cycle is given below:

- The DWPF Antifoam addition strategy was used:

- $\quad$ Add $200 \mathrm{ppm}$ antifoam to vessel prior to acid addition (at around $50^{\circ} \mathrm{C}$ ).

- $\quad$ Add 100 ppm antifoam after nitric acid addition (prior to formic acid addition).

- $\quad$ Add $500 \mathrm{ppm}$ antifoam after formic acid addition (prior to heating to boiling).

- $\quad$ Add $100 \mathrm{ppm}$ additional antifoam every 8 hours until the vessel temperature is below $50^{\circ} \mathrm{C}$.

- The slurry was heated to $93^{\circ} \mathrm{C}$.

- Nitric acid was added.

- Formic acid was added. An unplanned $100 \mathrm{ppm}$ addition of antifoam was made during formic acid addition when a small layer of bubbles was observed on the slurry.

- The slurry was heated to boiling.

- Water was removed. The volume of water was equivalent to the volume of acid and flush water additions.

- The slurry was refluxed for 12 hours. 
Table 4-2. DWPF and SRTC Scale SRAT Processing Parameters and Acid Addition Amounts

\begin{tabular}{lll}
\hline Parameter & DWPF Scale & SRTC Scale \\
\hline SRAT Contents & $6,000 \mathrm{gal}$ & $342 \mathrm{~mL}$ \\
Gas Purge Rate & $230 \mathrm{ft}^{3} / \mathrm{min}$ & $98 \mathrm{~cm}^{3} / \mathrm{min}$ \\
Acid Addition Rate & $2 \mathrm{gal} / \mathrm{min}$ & $0.12 \mathrm{~mL} / \mathrm{min}$ \\
Boil Up Rate & 5,000 pounds $/ \mathrm{hr}$ & $34 \mathrm{~g} / \mathrm{hr}$ \\
Acid Stoichiometry & $141 \%{ }^{\mathrm{a}}$ & $141 \%$ \\
Nitric Acid & $109 \mathrm{gal}^{\mathrm{a}}$ & $6.22 \mathrm{~mL}$ \\
Formic Acid & $563 \mathrm{gal}^{\mathrm{a}}$ & $32.07 \mathrm{~mL}$ \\
\hline
\end{tabular}

${ }^{a}$ DWPF scale stoichiometry and acid amounts are presented here for comparison purposes only.

At the completion of the SRAT cycle, the slurry was sampled and characterized.

\subsection{Results}

The SRTC SRAT cycle was completed per the run plan except for acid addition. Instead of taking approximately 4.5 hours to add the formic acid, the acid was added in under three hours due to improper adjustment of the occlusion on the acid addition peristaltic pump. No processing problems, such as major foaming or loss of heat transfer, were observed in the second SRAT cycle. The DWPF antifoam addition strategy was used. An extra $100 \mathrm{ppm}$ antifoam addition was made during formic acid addition when a layer of bubbles was observed on the slurry. This layer may have been caused by faster than planned acid addition. Also, nitrite was destroyed, mercury was removed, and the DWPF hydrogen generation rate was not exceeded.

\subsubsection{SRAT Cycle Product Characterization}

Presented in the following tables are the elements, weight percent solids, and anions necessary for SME blending and acceptability calculations from the second SRAT cycle product. These results show that nitrite and mercury were below detection limits in the SRAT cycle product $(<200 \mathrm{mg} / \mathrm{kg}$ for nitrite and $<0.023 \mathrm{wt} \%$ of total solids for mercury).

Table 4-3 lists the weight percent solids and density results of the second SRAT cycle product. As expected, total solids, soluble solids, and slurry and supernate densities increased due to the addition of soluble solids in the form of nitric and formic acids. Also contributing to the increase in soluble solids and decrease of insoluble solids is the dissolving of metal hydroxides during the SRAT cycle (see Section 4.2.4). 


\section{Revision 0}

Table 4-3. Weight Percent Solids and Density of the Second SRTC SRAT Cycle Product Using the Batch 3 Qualification Sample

\begin{tabular}{|c|c|}
\hline & Average (Std. Dev., \% Rel. Std. Dev.) \\
\hline Total Solids (wt $\%$ of slurry) ${ }^{a}$ & $29.9(0.05,0.2)$ \\
\hline Dissolved Solids (wt $\%$ of supernate) ${ }^{\mathrm{a}}$ & $17.2(0.04,0.2)$ \\
\hline Soluble Solids (wt $\%$ of slurry) ${ }^{b}$ & $14.6(0.05,0.3)$ \\
\hline Insoluble Solids (wt $\%$ of slurry) ${ }^{c}$ & $15.4(0.09,0.6)$ \\
\hline Calcined Solids (wt $\%$ of slurry) ${ }^{d}$ & $19.8(0.02,0.1)$ \\
\hline Slurry Density $(\mathrm{g} / \mathrm{mL})$ & $1.27(0.004,0.3)$ \\
\hline Supernate Density $(\mathrm{g} / \mathrm{mL})$ & $1.14(0.008,0.7)$ \\
\hline
\end{tabular}

Table 4-4 lists the elements measured in the SRAT cycle product total solids. Elements reported are those reported in Table 3-3 except for noble metals.

Table 4-4. Elements in the Sludge Batch 3 Second SRTC SRAT Cycle Product Necessary for
DWPF Blending Calculations Presented in Units of Weight Percent of Total Dried Solids

\begin{tabular}{|c|c|}
\hline Element & $\mathrm{Wt} \%$ of Total Solids (Std. Dev. , \% Rel. Std. Dev.) \\
\hline $\mathrm{Al}^{\mathrm{a}}$ & $4.77(0.247,5.2)$ \\
\hline $\mathrm{B}^{\mathrm{b}}$ & $0.317(0.074,23.4)$ \\
\hline $\mathrm{Ca}^{\mathrm{a}}$ & $1.22(0.017,1.4)$ \\
\hline $\mathrm{Cr}^{\mathrm{a}}$ & $0.086(0.034,40.1)$ \\
\hline $\mathrm{Cu}^{\mathrm{a}}$ & $<0.021$ (NA) \\
\hline $\mathrm{Fe}^{\mathrm{a}}$ & $12.5(0.829,6.6)$ \\
\hline $\mathrm{Hg}^{\mathrm{e}}$ & $<0.023$ (NA) \\
\hline $\mathrm{K}^{\mathrm{c}}$ & $0.060(0.005,8.5)$ \\
\hline $\mathrm{Li}^{\mathrm{a}}$ & $<0.058$ (NA) \\
\hline $\mathrm{Mg}^{\mathrm{a}}$ & $1.28(0.104,8.1)$ \\
\hline $\mathrm{Mn}^{\mathrm{d}}$ & $3.82(0.019,0.5)$ \\
\hline $\mathrm{Na}^{\mathrm{d}}$ & $13.2(0.37,2.8)$ \\
\hline $\mathrm{Ni}^{\mathrm{a}}$ & $0.813(0.051,6.3)$ \\
\hline $\mathrm{Si}^{\mathrm{b}}$ & $0.916(0.006,0.7)$ \\
\hline $\mathrm{Ti}^{\mathrm{a}}$ & $0.015(0.001,8.9)$ \\
\hline $\mathrm{U}^{\mathrm{a}}$ & $5.42(0.326,6.0)$ \\
\hline $\mathrm{Zr}^{\mathrm{d}}$ & $0.023(0.005,22.0)$ \\
\hline
\end{tabular}

${ }^{a}$ Average of eight measurements by ICP-ES (four aqua regia digestions and four peroxide fusion digestions).

${ }^{\mathrm{b}}$ Average of four measurements by ICP-ES (from peroxide fusion digestions).

${ }^{\mathrm{c}}$ Average of four measurements by AA (from aqua regia digestions).

${ }^{\mathrm{d}}$ Average of four measurements by ICP-ES (from aqua regia digestions).

${ }^{\mathrm{e}}$ Determined from AA of aqua regia digestion.

Presented in Table 4-5 are the measured anions and SRAT cycle product $\mathrm{pH}$ on a slurry basis. All of the anions except oxalate were calculated from IC analysis of the SRAT cycle product supernate. Oxalate was determined by IC analysis of a slurry sample diluted with acid. 
Table 4-5. Measured Anions and Final pH in the Second SRTC SRAT Product

\begin{tabular}{|c|c|}
\hline Anion & $\begin{array}{c}\text { Concentration in } \mathrm{mg} / \mathrm{kg} \text { (Std. Dev. (mg/kg), \% } \\
\text { Rel. Std. Dev.) }\end{array}$ \\
\hline Fluoride $^{a}$ & $<30$ (NA) \\
\hline Formate $^{a}$ & $61,700(1,500,2.5)$ \\
\hline Chloride $^{a}$ & $<30$ (NA) \\
\hline Nitrite $^{a}$ & $<200(\mathrm{NA}, \mathrm{NA})$ \\
\hline Nitrate $^{\mathrm{a}}$ & $38,100(850,2.2)$ \\
\hline Phosphate $^{\text {a }}$ & $<200$ (NA) \\
\hline Sulfate ${ }^{a}$ & $2,300(29,1.2)$ \\
\hline Oxalate $^{b}$ & $1,200(120,9)$ \\
\hline $\mathrm{pH}$ & $5.2(\mathrm{NA})$ \\
\hline
\end{tabular}

\subsubsection{Offgas Generation}

Maximum DWPF scale gas generation rates are presented in Table 4-6.

Table 4-6. Maximum Observed DWPF Scale Hydrogen, Carbon Dioxide, and Nitrous Oxide Concentrations and Generation Rates During the Sludge Batch 3 SRAT Cycle in the SRTC Shielded Cells

\begin{tabular}{cccc}
\hline & $\begin{array}{c}\text { Maximum } \\
\text { Observed Volume } \\
\text { Gas }\end{array}$ & & $\begin{array}{c}\text { Maximum Gas } \\
\text { Generation Rate } \\
(\mathrm{lb} / \mathrm{hr})\end{array}$ \\
\cline { 1 - 2 } Hydrogen & 0.023 & & 0.017 \\
Carbon Dioxide & 25 & & 516 \\
Nitrous Oxide & 6.7 & 131 \\
\hline
\end{tabular}

Figure 4-2 shows a plot of carbon dioxide, nitrous oxide, and hydrogen generation rates on a DWPF scale plotted relative to the completion of acid addition. Based on these diagrams, the SRAT cycle behaved as expected. Carbon dioxide evolved during and immediately after acid addition, indicating destruction of carbonate and some destruction of formic acid. Nitrous oxide evolved during and after acid addition, indicating nitrite destruction. Hydrogen generation peaked about two hours after acid addition and nitrous oxide generation dropped significantly, giving an indication of the completion of nitrite destruction. These results compare well with simulant work. A detailed comparison of simulant SRAT cycles and this SRAT cycle can be found in Appendix F. 


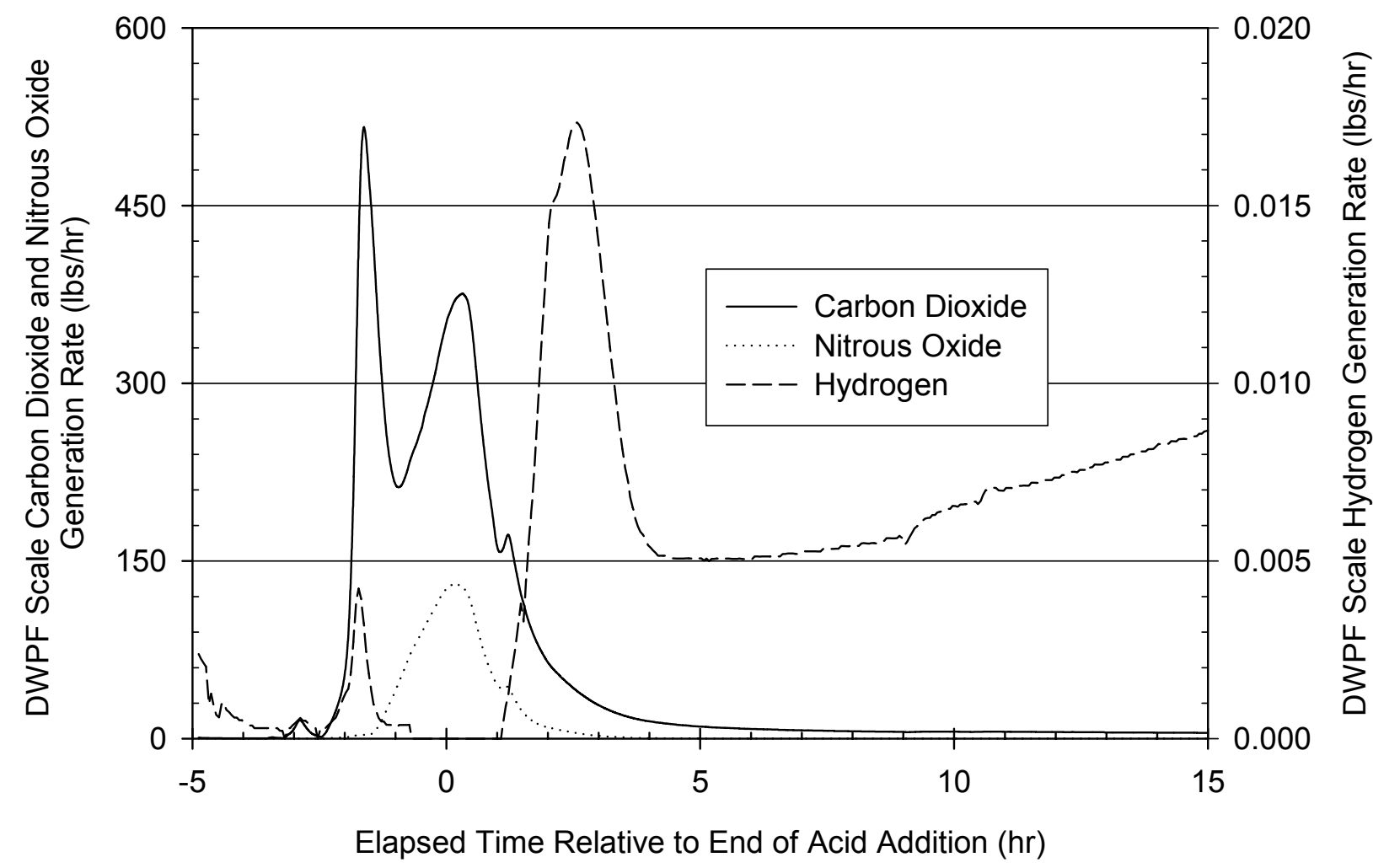

Figure 4-2 Gas Generation During the Second SRTC SRAT Cycle

\subsubsection{Nitrite, Formate, and Oxalate Destruction}

Several assumptions for anion destruction/conversion were made for the acid calculation (see Table 4-1). These assumptions involve nitrite to nitrate conversion, formate destruction, and oxalate destruction. Although the assumptions are based on overall processing (SRAT and SME cycles), SRAT cycle destruction/conversion is presented for information in Table 4-7. Overall destruction/conversion and comparison to acid calculation assumptions is presented in Section 5.2.3.

Table 4-7. SRAT Cycle Nitrite to Nitrate conversion, \% Formate Destruction, and \% Oxalate Destruction and Comparison to Acid Calculation Assumptions

\begin{tabular}{ll}
\hline Nitrite Destruction $^{\dagger}$ & $100 \%$ \\
Nitrite to Nitrate Conversion (molar basis) & $33 \%$ \\
Formate Destruction & $19 \%$ \\
Oxalate Destruction & $39 \%$ \\
\hline If the detection limit from Table $4-5$ of $200 \mathrm{mg} / \mathrm{kg}$ were used, nitrite \\
destruction would be calculated to be $99 \%$.
\end{tabular}

\subsubsection{Elements Dissolved From the Sludge During the SRAT Cycle}

During the SRAT cycle, elements dissolve from the sludge solids into the supernate as the vessel contents are acidified. As expected, aluminum solubility decreased while calcium, manganese, magnesium, and 
uranium solubilities increased. Table 4-8 shows supernate concentrations in the SRAT feed and SRAT cycle product and the calculated percent soluble in the SRAT cycle product for selected elements. The percent soluble was calculated as follows:

$$
\cdot \frac{C_{i} \cdot\left(1-W_{I S}\right)}{W_{T S} \cdot W_{i} \cdot 100}
$$

where,

$C_{i}=$ concentration of element $i$ in the supernate $(\mathrm{mg} / \mathrm{kg})$

$W_{I S}=$ weight $\%$ insoluble solids in the slurry $\left(100-W_{I S}\right.$ is the weight $\%$ supernate in the slurry)

$W_{T S}=$ weight $\%$ total solids in the slurry

$W_{i}=$ weight $\%$ of element $i$ in the total solids.

Table 4-8. Supernate Concentrations and Percent Soluble for Selected Elements in the SRAT Cycle Product

\begin{tabular}{lccc}
\hline Element & $\begin{array}{c}\text { Concentration in } \\
\text { SRAT Feed } \\
\text { Supernate } \\
(\mathrm{mg} / \mathrm{kg})\end{array}$ & $\begin{array}{c}\text { Concentration in } \\
\text { SRAT Cycle Product } \\
\text { Supernate }(\mathrm{mg} / \mathrm{kg})\end{array}$ & $\begin{array}{c}\text { Percent } \\
\text { Soluble in } \\
\text { SRAT } \\
\text { Product }\end{array}$ \\
\hline $\mathrm{Al}$ & 1,080 & 40 & 0 \\
$\mathrm{Ca}$ & $<30$ & 1,920 & 45 \\
$\mathrm{Fe}$ & $<1$ & 6 & 0 \\
$\mathrm{Mg}$ & $<4$ & 3,230 & 71 \\
$\mathrm{Mn}$ & $<1$ & 5,500 & 41 \\
$\mathrm{Na}$ & 38,000 & 34,600 & 74 \\
$\mathrm{Ni}$ & $<5$ & 70 & 2 \\
$\mathrm{U}$ & $<50$ & 12,900 & 67 \\
\hline
\end{tabular}


WSRC-TR-2004-00050

Revision 0

This page intentionally left blank. 


\subsection{SME CYCLE}

\subsection{Approach}

A SME cycle using the product from the second SRAT cycle (see Section 4.0) was completed per a run plan $^{19}$. See Section 4.1.1 for an equipment description. To determine frit amount, a waste loading of $35 \%{ }^{20}$ was used. The frit quantity was determined by multiplying the weight of the calcined solids in the feed by the targeted ratio of calcined waste to frit $(65 \%$ frit $/ 35 \%$ calcined waste) in the final glass:

$$
270 \mathrm{~mL} \text { slurry } \cdot \frac{1.27 \mathrm{~g} \text { slurry }}{\mathrm{mL} \text { slurry }} \cdot \frac{198 \mathrm{~g} \text { calcined solids }}{\mathrm{g} \text { slurry }} \cdot \frac{0.65 \mathrm{~g} \text { frit }}{0.35 \mathrm{~g} \text { calcined solids }}=126 \mathrm{~g} \text { frit }
$$

Table 5-1 summarizes processing parameters, frit amount, and formic acid amount used in the SRTC SME cycle.

Table 5-1. DWPF and SRTC Scale SME Processing Parameters

\begin{tabular}{lll}
\hline Parameter & DWPF Scale & SRTC Scale \\
\hline SME Contents & 6,000 gal & $270 \mathrm{~mL}$ \\
Gas Purge Rate & $74 \mathrm{ft}^{3} / \mathrm{min}$ & $26 \mathrm{~cm}^{3} / \mathrm{min}$ \\
Decon Water per Canister & 1,500 gal & $68 \mathrm{~mL}$ \\
Boil Up Rate & 5,000 pounds $/ \mathrm{hr}$ & $27 \mathrm{~g} / \mathrm{hr}$ \\
Frit 202 & 23,000 pounds & $126 \mathrm{~g}$ \\
$1.5 \mathrm{wt} \%$ Formic Acid & & \\
$\quad$ Solution & 23,000 pounds & $126 \mathrm{~g}$ \\
\hline
\end{tabular}

Following is a summary of the SME cycle steps.

- One hundred ppm of IIT747 antifoam were added to the SRAT/SME vessel every eight hours when the vessel temperature was above $50^{\circ} \mathrm{C}$.

- The vessel was heated to boiling and an amount of water required for the decontamination of one canister was added. The added water was then removed at the boil up rate given in Table 5-1. This water addition/removal was completed five times to simulate the addition and removal of water for the decontamination of five canisters.

- Half of the required frit and formic acid solution was added. Frit and formic acid were poured into the vessel, not pumped.

- A volume of water equivalent to the volume of the added formic acid solution was removed.

- The frit/formic acid solution addition and subsequent water removal were repeated with the remaining frit and formic acid solution.

- The vessel was then refluxed so that the total SME cycle would be approximately 40 hours.

After the SME cycle, a sample of the SME product slurry was taken for density and percent solids measurements. Samples were also submitted for anion and total organic carbon determination.

\subsection{Results}

During the SME cycle, no processing problems were observed and the DWPF hydrogen generation limit was not exceeded. 
WSRC-TR-2004-00050

\section{Revision 0}

\subsubsection{SME Cycle Product Characterization}

Presented in Table 5-2 are percent solids and densities of the SME product. The results were as expected.

Table 5-2. Weight Percent Solids and Density of the SRTC SME Cycle Product Using the Sludge Batch 3 Qualification Sample

\begin{tabular}{|c|c|}
\hline & Average (Std. Dev., \%Rel. Std. Dev.) \\
\hline Total Solids (wt $\%$ of slurry) ${ }^{\mathrm{a}}$ & $47.9(0.34,0.7)$ \\
\hline Dissolved Solids ( $\mathrm{wt} \%$ of supernate) ${ }^{\mathrm{a}}$ & $15.9(0.02,0.1)$ \\
\hline Soluble Solids (wt $\%$ of slurry) $)^{\mathrm{b}}$ & $9.9(0.05,0.5)$ \\
\hline Insoluble Solids (wt $\%$ of slurry) ${ }^{c}$ & $38.1(0.39,1.0)$ \\
\hline Calcined Solids (wt $\%$ of slurry $)^{d}$ & $40.7(1.19,2.9)$ \\
\hline Slurry Density $(\mathrm{g} / \mathrm{mL})$ & $1.44(0.005,0.3)$ \\
\hline Supernate Density $(\mathrm{g} / \mathrm{mL})$ & $1.12(0.001,0.1)$ \\
\hline
\end{tabular}

Table 5-3 shows the SME cycle product slurry anions, total organic carbon, and pH results. As in the SRAT cycle product, all of the anions except oxalate were calculated from IC analysis of the supernate. Oxalate was determined by IC analysis of a slurry sample diluted with acid. Total organic carbon was measured on two diluted slurry samples. As can be seen from the high relative standard deviation, the results are not precise. However, if one coverts the formate content (the primary source of organic carbon in the SME cycle product) to total organic carbon, the result is $9,300 \mathrm{mg} / \mathrm{kg}$. Therefore, while the TOC analysis is imprecise, it may be bounding.

Table 5-3. Measured Anions, Total Organic Carbon, and pH in the SME Cycle Product Slurry

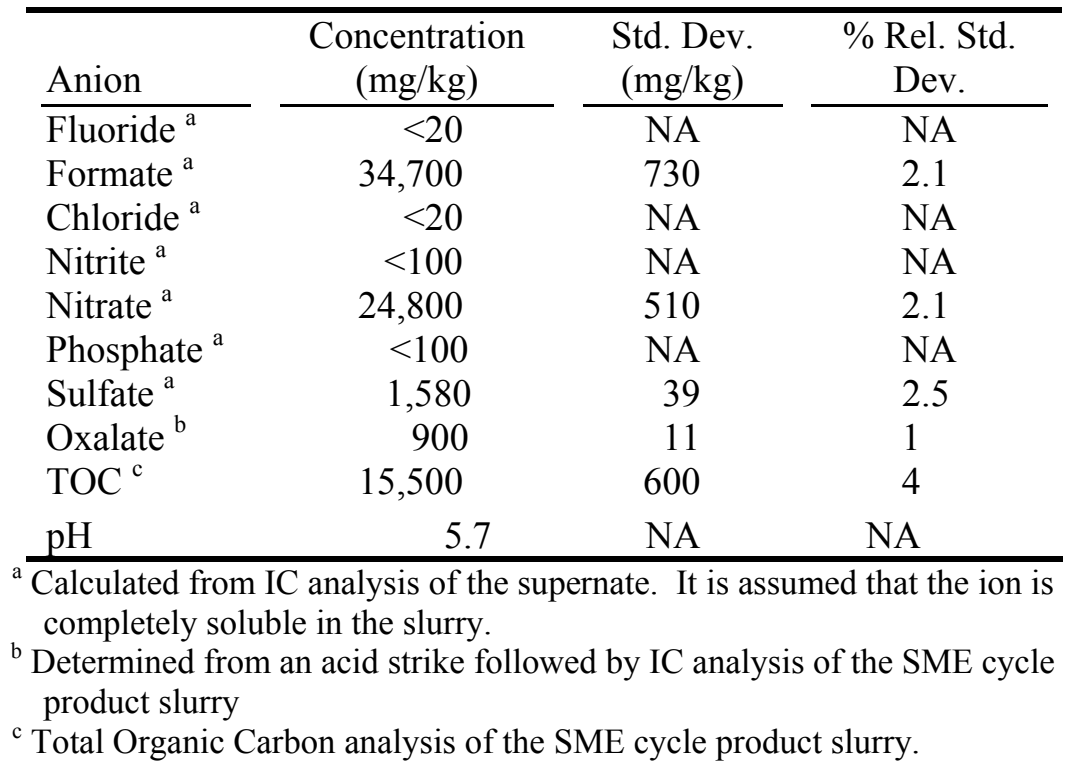




\subsubsection{SME Cycle Gas Generation}

During the SME cycle, the offgas was monitored for hydrogen, carbon dioxide, and nitrous oxide. Maximum observed concentrations and DWPF scale generation rates are given in Table 5-4.

Table 5-4. Maximum Observed DWPF Scale Hydrogen, Carbon Dioxide, and Nitrous Oxide Concentration and Generation Rates During the Sludge Batch 3 SME Cycle in the SRTC Shielded Cells

\begin{tabular}{|c|c|c|}
\hline Gas & $\begin{array}{l}\text { Maximum } \\
\text { Observed } \\
\text { Volume \% } \\
\end{array}$ & $\begin{array}{c}\text { Maximum Gas } \\
\text { Generation Rate } \\
(\mathrm{lb} / \mathrm{hr})\end{array}$ \\
\hline Hydrogen & 0.17 & 0.044 \\
\hline Carbon Dioxide & 2.2 & 13.6 \\
\hline Nitrous Oxide & 0.31 & 1.85 \\
\hline
\end{tabular}

The gas generation rates are plotted in Figure 5-1. Note that the dips in gas generation are due to the breach of the vessel during decontamination water and frit/formic acid solution additions. As can be seen from the figure, maximum hydrogen generation occurred at the end of the SME cycle. This implies that if the SME cycle continued, hydrogen generation would continue to increase. However, if one were to extrapolate the last four hours of the graph, it would take more than 24 hours to reach the DWPF limit of $0.223 \mathrm{lbs} / \mathrm{hr}$. 


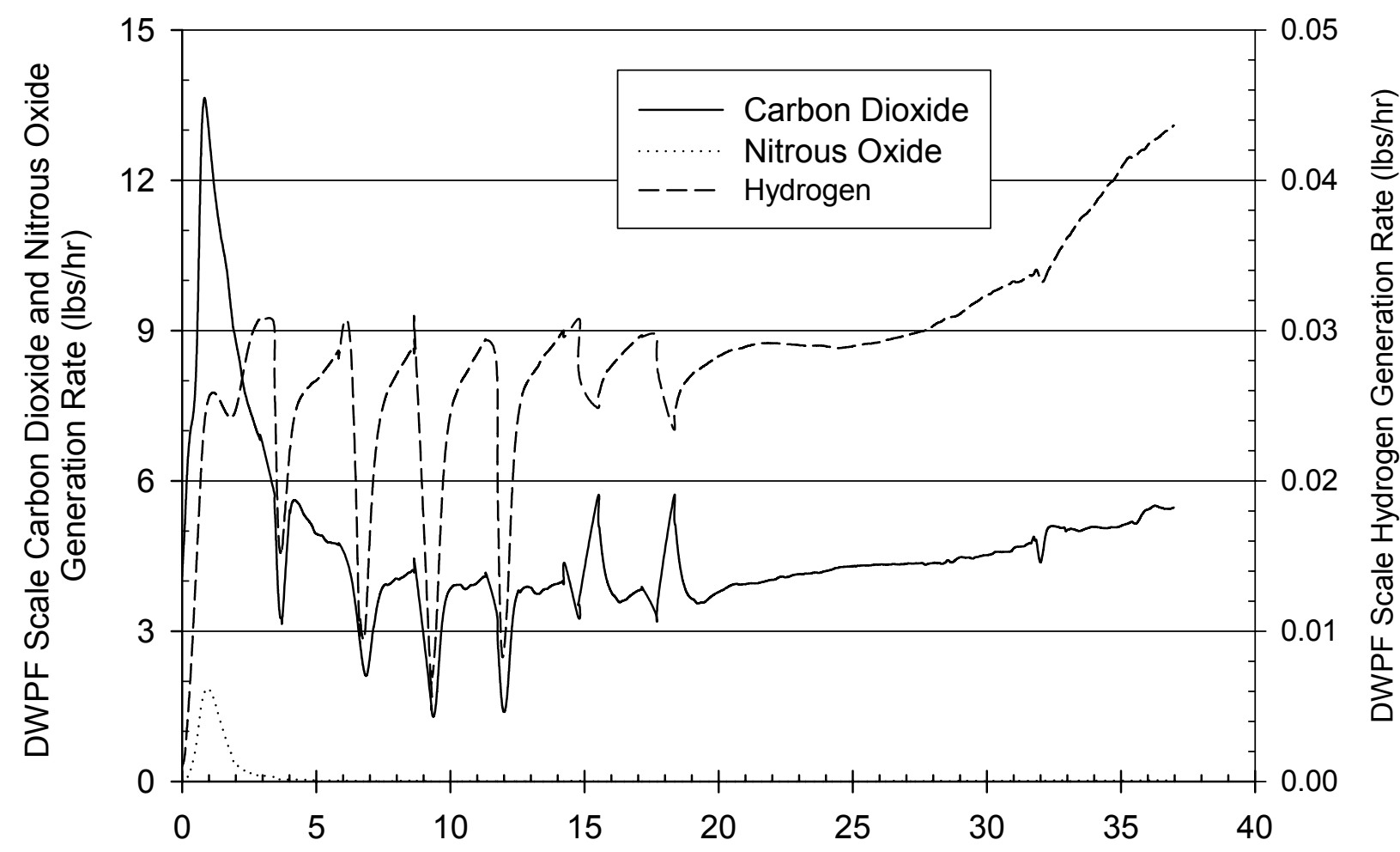

Elapsed Time Relative to Start of Boiling (hr)

Figure 5-1. SME Cycle Gas Generation Rates

\subsubsection{Overall Anion destruction/conversion and Comparison to Acid Calculation Assumptions}

Several assumptions for anion destruction/conversion were made for the acid calculation (see Table 4-1). These assumptions involve nitrite to nitrate conversion, formate destruction, and oxalate destruction. Presented in Table 5-5 are the calculated nitrite destruction, nitrite to nitrate conversion, formate destruction, and oxalate destruction for the SRAT cycle, SME cycle, and overall SRAT/SME process. Mass balance and calculations for the table are given in Appendix G.

Table 5-5. Calculated Nitrite Destruction, Nitrite to Nitrate conversion, \% Formate Destruction, and \% Oxalate Destruction and Comparison to Acid Calculation Assumptions

\begin{tabular}{|c|c|c|c|c|}
\hline & \multicolumn{3}{|c|}{ SME } & \multirow[b]{2}{*}{ Assumed } \\
\hline & SRAT Cycle & Cycle & Overall & \\
\hline Nitrite Destruction & $100 \%$ & $\mathrm{~N} / \mathrm{A}$ & $100 \%$ & $100 \%$ \\
\hline Nitrite to Nitrate Conversion (molar & & & & \\
\hline basis) & $28 \%$ & N/A & $25 \%{ }^{a}$ & $32.4 \%$ \\
\hline Formate Destruction & $19 \%$ & $29 \%$ & $42 \%$ & $25.2 \%$ \\
\hline Oxalate Destruction & $39 \%$ & $0 \%$ & $39 \%$ & $57.7 \%$ \\
\hline
\end{tabular}


The differences between the actual and assumed conversions/destructions impact only the predicted redox. The amounts of formic and nitric acids can be adjusted during DWPF processing to adjust predicted redox as necessary. The comparison between predicted and actual conversion/destruction may not even be applicable due to differences between SRTC and DWPF condensate treatment (e.g., how condensate is collected and allowed to flow back to the SRAT/SME). This comparison may be more appropriate in evaluating SRTC simulant and radioactive work. A detailed comparison of this work and the supporting simulant work can be found in Appendix F. 
WSRC-TR-2004-00050

Revision 0

This page intentionally left blank. 


\subsection{FORMIC ACID ADDITION}

Additional formic acid was added to the SME cycle product to evaluate hydrogen generation. While hydrogen generation rates did increase, they were still below DWPF limits.

\subsection{Approach}

Formic acid was added to the SME cycle product in two stages. First, an equivalent of 45 gallons of 90 $\mathrm{wt} \%$ formic acid was added ${ }^{\dagger}$. The vessel contents were then refluxed for over five hours. A second addition of formic acid equivalent to 235 gallons was then added, and the SME contents were refluxed over six hours.

\subsection{Results}

The results of the two formic acid additions are shown graphically in Figure 6-1 and Figure 6-2. Based on Figure 6-1, there are no hydrogen issues with the addition of 50 gallons (nominal) of formic acid to the SME cycle product. After more than four hours of boiling, hydrogen generation remained constant.

Figure 6-2 shows that an addition of an additional 235 gallons of formic acid (280 gallons total) does not immediately impact hydrogen generation. However, after four hours of boiling, hydrogen generation rate did begin to increase.

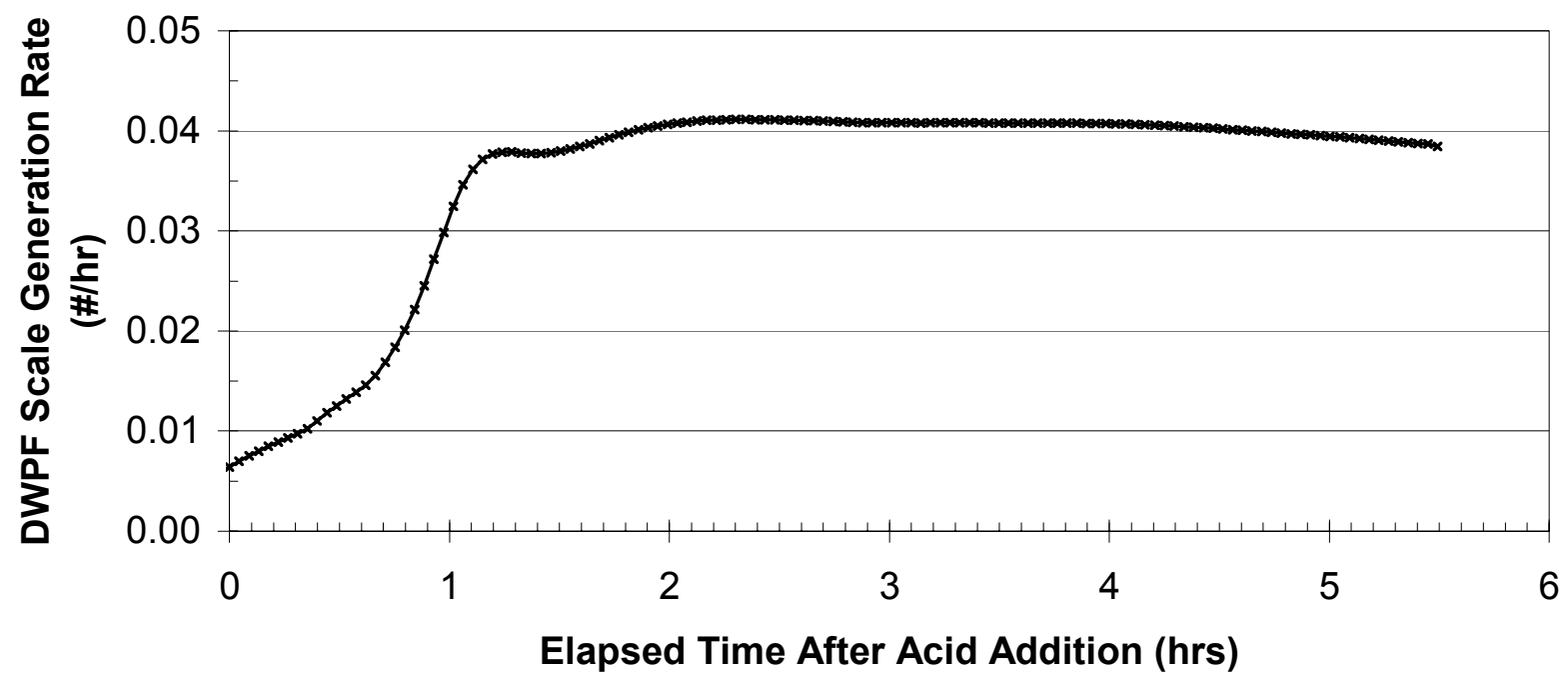

Figure 6-1. Hydrogen Generation Rate After the Addition of 45 Gallons (DWPF Scale) of 90wt\% Formic Acid to SME Cycle Product

\footnotetext{
${ }^{\dagger}$ The amount of acid was based on a DWPF scale SME volume of 6,000 gallons. The target amount of formic acid was 50 gallons.
} 
WSRC-TR-2004-00050

Revision 0

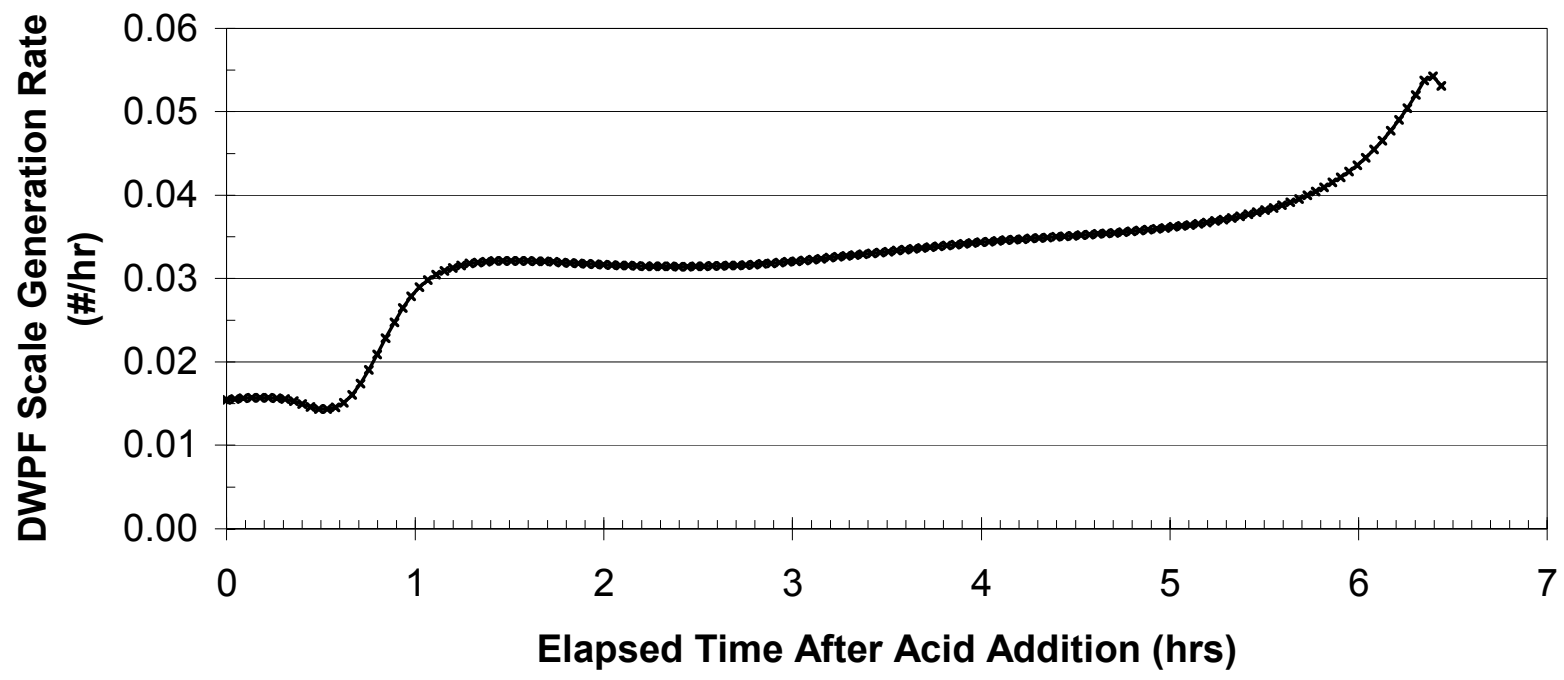

Figure 6-2. Hydrogen Generation Rate After the Addition of 235 Gallons (DWPF Scale) of 90wt\% Formic Acid to SME Cycle Product 


\subsection{GLASS FABRICATION}

This section describes the results obtained from the final glass characterization for Sludge Batch 3 SRAT1 product blended with Frit 202 in the SRTC Shielded Cells Facility.

The recommended waste loading targeted for this glass was $35 \%{ }^{20}$. Using the normalized lithium oxide content of the glass and frit, the calculated waste loading was $30.2 \%$. The normalized release of boron indicates that the glass met the Waste Acceptance Product Specifications 1.3 (WAPS) ${ }^{21}$ (as measured by the Product Consistency Test $(\mathrm{PCT})^{22}$ ). The measured melter feed (Sludge Batch 3-SRAT-1 product/Frit 202 blend) had predicted processing properties that were acceptable ${ }^{23}$.

\subsection{Approach}

\subsubsection{Calculations for Blending}

The final processing step for the acidified sludge slurry (product after the SRAT cycle) is the addition of a frit during the SME cycle. The resultant blended feed is then vitrified. In the DWPF process, the frit is a pre-melted mixture of chemicals that facilitate the vitrification of the processed sludge into a durable glass. After the addition of the pre-formed frit to the SRAT product, the feed is metered into a jouleheated melter operating at $1150^{\circ} \mathrm{C}$. The glass is poured into stainless steel canisters and stored until shipment to a repository.

\subsubsection{Preparation of Sludge Batch 3/Frit 202 Glass}

The glass was prepared remotely by drying and melting the SRAT-1 product slurry and Frit 202 in a 100$\mathrm{ml}$ platinum crucible in a programmable electric furnace in Cell 1 of the SRTC Shielded Cells. The crucible was partially filled with SRAT-1 product. Frit 202 was then added to the crucible to target a $35 \%$ waste loading as prescribed in Reference 20. The crucible was placed in a drying oven in Cell 1 at approximately $104^{\circ} \mathrm{C}$ for 16 hours (overnight) to dry. The crucible containing the SRAT-1 product/Frit 202 was then placed into a high-temperature furnace. The furnace was programmed to take four hours to heat to $1150{ }^{\circ} \mathrm{C}$. After the furnace reached $1150^{\circ} \mathrm{C}$, the temperature was maintained for 4 hours. The heating steps (drying, ramped heating, and high-temperature hold) are to ensure dryness, decomposition of the nitrates and nitrites, and a homogeneous melt. The crucible was then removed from the furnace at temperature. The glass was quenched by partially submerging the crucible in water and then allowed to cool to ambient temperature in the cell. After several hours, the glass was removed from the crucible by tapping on the base of the crucible.

\subsection{Results}

\subsubsection{Chemical Composition of Sludge Batch 3/Frit 202 Glass}

A portion of the glass was pulverized using agate balls and vial (mortar and pestle). The measured elemental composition of the Sludge Batch 3/Frit 202 glass was obtained by dissolving a sample of the ground glass and analyzing the resulting solutions using Inductively Coupled Plasma - Emission Spectroscopy (ICP-ES). Dissolution of the glass samples was performed remotely in the Shielded Cells of SRTC. A portion of the Sludge Batch 3/Frit 202 glass sample was dissolved in quadruplicate by two separate dissolution methods, mixed acid dissolution and sodium peroxide fusion, according to approved

\footnotetext{
* The lower than predicted waste loading may have been caused by analytical error. Both the frit and glass oxide compositions totaled less than $100 \%$.
} 


\section{Revision 0}

procedures. The acid dissolution method uses boric acid to complex the fluoride used to help dissolve the glass. Thus, the boron content of the glass cannot be obtained by this method. The sodium peroxide fusion uses sodium peroxide and sodium hydroxide to render the glass more soluble. Thus, the sodium content of the glass cannot be obtained by this method. The peroxide fusions were performed in zirconium crucibles; thus the zirconium content of the glass could not be obtained by this dissolution method. A standard glass with a composition similar to the DWPF glass, Analytical Reference Glass-1 $(\mathrm{ARG})^{24}$, was also dissolved and analyzed concurrently with the Sludge Batch 3/Frit 202 glass. Table 7-1 shows the measured and published composition for ARG.

Table 7-1. Published and Average Measured Values of Analytical Reference Glass-1.

\begin{tabular}{cccc}
\hline & $\begin{array}{c}\text { Measured } \\
(\text { wt.\%) }\end{array}$ & $\begin{array}{c}\text { Published }^{24} \\
\text { (wt.\%) }\end{array}$ & Measured/Published \\
\hline $\mathrm{Al}_{2} \mathrm{O}_{3}$ & 4.22 & 4.72 & 0.89 \\
$\mathrm{~B}_{2} \mathrm{O}_{3}$ & 8.18 & 8.66 & 0.94 \\
$\mathrm{BaO}$ & 0.08 & 0.09 & 0.89 \\
$\mathrm{CaO}$ & 1.55 & 1.53 & 1.01 \\
$\mathrm{Cr}_{2} \mathrm{O}_{3}$ & 0.10 & 0.09 & 1.11 \\
$\mathrm{Fe}_{2} \mathrm{O}_{3}$ & 14.2 & 14.00 & 1.02 \\
$\mathrm{Li}_{2} \mathrm{O}$ & 3.49 & 3.21 & 1.09 \\
$\mathrm{MgO}$ & 1.05 & 0.86 & 1.22 \\
$\mathrm{MnO}$ & 1.85 & 2.31 & 0.80 \\
$\mathrm{Na} \mathrm{O}_{2}$ & 12.0 & 11.48 & 1.04 \\
$\mathrm{NiO}$ & 1.08 & 1.05 & 1.03 \\
$\mathrm{SiO}$ & 48.5 & 47.92 & 1.01 \\
$\mathrm{SrO}_{\mathrm{TiO}}$ & 0.28 & 0.00 & -- \\
$\mathrm{ZnO}$ & 1.16 & 1.15 & 1.01 \\
$\mathrm{ZrO}$ & 0.03 & 0.02 & 1.50 \\
$\mathrm{Total}$ & 0.14 & 0.13 & 1.08 \\
\hline
\end{tabular}

${ }^{a}$ Average of eight measurements by ICP-ES (four aqua regia digestions and four peroxide fusion digestions) except $\mathrm{B}$ (average of four peroxide fusion digestions), and $\mathrm{Na}$ and $\mathrm{Zr}$ (average of four mixed acid digestions).

Table 7-2 shows the elemental weight percents of the major components in the glass made from the SRAT-1/Frit 202 product. Table 7-3 presents the same data, with the elements converted to their oxide forms. 
Table 7-2. Elemental Composition of Glass Fabricated With Sludge Batch 3 Material and Frit 202

\begin{tabular}{|c|c|c|c|}
\hline Element & $\begin{array}{l}\mathrm{Wt} \% \text { of } \\
\text { Glass }{ }^{\mathrm{a}}\end{array}$ & Std. Dev. & $\begin{array}{c}\text { \% Rel. Std. } \\
\text { Dev. }\end{array}$ \\
\hline $\mathrm{Al}$ & 2.57 & 0.094 & 3.7 \\
\hline B & 1.42 & 0.045 & 3.2 \\
\hline $\mathrm{Ca}$ & 0.73 & 0.089 & 12.2 \\
\hline $\mathrm{Cr}$ & 0.04 & 0.008 & 19.5 \\
\hline $\mathrm{Cu}$ & $<0.03$ & NA & NA \\
\hline $\mathrm{Fe}$ & 6.41 & 0.213 & 3.3 \\
\hline $\mathrm{K}^{\mathrm{b}}$ & 0.03 & 0.004 & 12.3 \\
\hline $\mathrm{Li}$ & 2.17 & 0.076 & 3.5 \\
\hline $\mathrm{Mg}$ & 1.44 & 0.053 & 3.7 \\
\hline $\mathrm{Mn}$ & 1.81 & 0.058 & 3.2 \\
\hline $\mathrm{Na}$ & 9.63 & 0.270 & 2.8 \\
\hline $\mathrm{Ni}$ & 0.41 & 0.022 & 5.5 \\
\hline $\mathrm{Si}$ & 23.8 & 1.7 & 7.1 \\
\hline $\mathrm{Ti}$ & 0.02 & 0.001 & 4.6 \\
\hline $\mathrm{U}$ & 2.71 & 0.082 & 3.0 \\
\hline $\mathrm{Zr}$ & 0.04 & 0.003 & 6.2 \\
\hline
\end{tabular}

${ }^{a}$ Average of eight measurements by ICP-ES (four aqua regia digestions and four peroxide fusion digestions) except $\mathrm{B}$ (average of four peroxide fusion digestions), and $\mathrm{Na}$ and $\mathrm{Zr}$ (average of four mixed acid digestions).

${ }^{\mathrm{b}}$ Calculated using the ratio of $\mathrm{K}$ and Fe in the SRAT cycle product (SME feed). $\mathrm{K}$ was not measured in the glass because it required an additional analysis and it was very low ( $0.06 \%$ of total solids) in the SME feed.

Table 7-3. Oxide Composition of Glass Fabricated With Sludge Batch 3 Material and Frit 202

\begin{tabular}{|c|c|c|c|}
\hline Oxide & $\begin{array}{l}\mathrm{Wt} \% \text { of } \\
\text { Glass }\end{array}$ & Std. Dev. & $\begin{array}{c}\text { \% Rel. Std. } \\
\text { Dev. }\end{array}$ \\
\hline $\mathrm{Al}_{2} \mathrm{O}_{3}$ & 4.86 & 0.177 & 3.7 \\
\hline $\mathrm{B}_{2} \mathrm{O}_{3}$ & 4.57 & 0.146 & 3.2 \\
\hline $\mathrm{CaO}$ & 1.02 & 0.125 & 12.2 \\
\hline $\mathrm{Cr}_{2} \mathrm{O}_{3}$ & 0.06 & 0.012 & 19.5 \\
\hline $\mathrm{CuO}$ & $<0.04$ & NA & NA \\
\hline $\mathrm{Fe}_{2} \mathrm{O}_{3}$ & 9.16 & 0.305 & 3.3 \\
\hline $\mathrm{K}_{2} \mathrm{O}$ & 0.04 & 0.004 & 12.3 \\
\hline $\mathrm{Li}_{2} \mathrm{O}$ & 4.68 & 0.164 & 3.5 \\
\hline $\mathrm{MgO}$ & 2.39 & 0.088 & 3.7 \\
\hline $\mathrm{MnO}$ & 2.33 & 0.075 & 3.2 \\
\hline $\mathrm{Na}_{2} \mathrm{O}$ & 13.0 & 0.363 & 2.8 \\
\hline $\mathrm{NiO}$ & 0.52 & 0.029 & 5.5 \\
\hline $\mathrm{SiO}_{2}$ & 51.0 & 3.637 & 7.1 \\
\hline $\mathrm{TiO}_{2}$ & 0.04 & 0.002 & 4.6 \\
\hline $\mathrm{U}_{3} \mathrm{O}_{8}$ & 3.19 & 0.097 & 3.0 \\
\hline $\mathrm{ZrO}_{2}$ & 0.06 & 0.004 & 6.2 \\
\hline Total & 96.92 & NA & NA \\
\hline
\end{tabular}


WSRC-TR-2004-00050

Revision 0

\subsubsection{Product Consistency Test (PCT)}

Quadruplicate samples of the Sludge Batch 3/Frit 202 glass and the Environmental Assessment (EA) glass $^{25}$ were leached in the PCT. Results appear in Table 7-4. This test is the standard ASTM C 1285-02 test $^{22}$. Its procedure requires that the radioactive and EA glasses be leached at $90^{\circ} \mathrm{C}$ for seven days along with blanks and the standard (ARM) glass ${ }^{26}$. Results for the blanks and ARM glass indicated that the conditions of the test were controlled as the American Society of Testing and Materials (ASTM) procedure prescribes. Table 7-4 gives the averages of the results in terms of normalized releases for the SB3/Frit 202 and the EA glass based on the amounts of B, Li, and $\mathrm{Na}$ in the respective glasses. Predicted values for the release from the SB3/Frit 202 glass along with the published and measured values for the releases from the EA glass are also included in Table 7-4. The measured and published values for the releases from the EA glass are in good agreement, again indicating that the test was controlled as the ASTM procedure prescribes. One criterion for glass acceptability is that the release for the SB3/Frit 202 glass based on $\mathrm{B}, \mathrm{Li}$, and $\mathrm{Na}$, shall be two standard deviations below the mean PCT results of the EA glass. Comparisons of the results in column three with results in columns five or six of Table 7-4 indicate that this is indeed the case.

Table 7-4. Normalized Mass Releases (Grams Glass/Liter) Based on B, Li, and Na for Sludge Batch 3/Frit 202 Glass and EA Glass in a $90^{\circ} \mathrm{C}$ PCT

\begin{tabular}{|c|c|c|c|c|c|}
\hline \multirow[b]{2}{*}{ Element } & \multicolumn{3}{|c|}{ SB3 SRAT 1 Glass } & \multicolumn{2}{|c|}{ EA Glass } \\
\hline & $\begin{array}{c}\text { Measured } \\
\text { Release, Std. } \\
\text { Dev }^{\text {a }}\end{array}$ & $\begin{array}{c}\text { Release Plus } 2 \\
\text { Std. Dev. }\end{array}$ & $\begin{array}{l}\text { Predicted } \\
\text { Release }^{\mathrm{b}}\end{array}$ & $\begin{array}{c}\text { Measured } \\
\text { Release, Std. } \\
\text { Dev. }{ }^{\text {a }}\end{array}$ & $\begin{array}{c}\text { Published } \\
\text { Release, Std } \\
\text { Dev. }\end{array}$ \\
\hline B & $1.01,0.01$ & 1.03 & 1.26 & $17.0,0.3$ & $16.7,1.2$ \\
\hline $\mathrm{Li}$ & $0.911,0.013$ & 0.937 & 1.19 & $9.35,0.21$ & $9.57,0.7$ \\
\hline $\mathrm{Na}$ & $1.01,0.02$ & 1.03 & 1.22 & $13.0,0.2$ & $13.3,0.9$ \\
\hline
\end{tabular}

${ }^{\mathrm{a}}$ Based on quadruplicate samples in a Product Consistency Test.

${ }^{\mathrm{b}}$ Calculated using PCCS version 5.0 and documented in Reference 27.

${ }^{\mathrm{c}}$ Reference 25 


\subsection{CONCLUSIONS}

Sludge Batch 3, as defined in this report, can be processed by DWPF:

- SRAT processing accomplished the goals of nitrite destruction and mercury removal without exceeding DWPF hydrogen generation limits and nitrous oxide concentration limits. No significant issues (mixing, heat transfer, foaming) were observed.

- There were no processing issues with the SME cycle. Hydrogen generation was below DWPF limits. No excessive foaming was observed. No problems with concentrating the contents (heat transfer) or mixing were observed.

- The glass produced from this demonstration met the durability acceptance criteria as defined in the WAPS. The releases of $\mathrm{B}, \mathrm{Li}$, and $\mathrm{Na}$ in the PCT were at least two standard deviations better than the EA glass.

- The addition of $90 \%$ formic acid to the SME product was not accompanied by a significant increase in hydrogen generation compared to that observed in the rest of the SME cycle. 
WSRC-TR-2004-00050

Revision 0

This page intentionally left blank. 


\subsection{REFERENCES}

1. Rios-Armstrong, M. A. Sludge Batch 3 SRTC Shielded Cells Testing; Technical Task Request, HLW/DWPF/TTR-03-0005, Rev. 1; Savannah River Site: Aiken, SC, June 2003.

2. $\quad$ Pareizs, J. M.; Click, D. R.; Bibler, N. E.; Cozzi, A. D. Data From the SRTC Shielded Cells Demonstration of the Defense Waste Processing Facility's Feed Preparation Cycles for Sludge Batch 3, WSRC-RP-01102; Savannah River Site: Aiken, SC, December 2003.

3. Bibler, N. E. Sludge Batch 3 Acceptance Evaluation - Radionuclide Concentrations in Tank 51 Sludge Batch Three Qualification Sample Prepared at SRTC, WSRC-RP-2003-01008; Savannah River Site: Aiken, SC, October 2003.

4. Pareizs, J. M. Task Technical and Quality Assurance Plan for the Washing and Qualification of Sludge Batch 3 Radioactive Sludge Slurry (U), WSRC-RP-2003-00249, Rev. 1; Savannah River Site: Aiken, SC, March 2003.

5. Pareizs, J. M. Analytical Study Plan for Qualification of Sludge Batch 3 Radioactive Sludge Slurry in the SRTC Shielded Cells, WSRC-RP-2003-00250, Rev. 1; Savannah River Site: Aiken, SC, March 2003.

6. Swingle, R. F. Results of Tank 51H Sludge Batch 3 Qualification Sample WAC and Corrosion Control Analyses (HTF-E-03-76), Interoffice Memorandum SRT-LWP-2003-00062; Savannah River Site: Aiken, SC, July 2003.

7. Click, D. R. Elemental Composition of Initial Tank Fifty One Sample Including Noble Metals, Interoffice Memorandum SRT-ADS-2003-0390; Savannah River Site: Aiken, SC, July 2003.

8. Click, D. R. Oxalate Concentration in Tank Fifty One Using an Acid Dissolution Technique, Interoffice Memorandum SRT-ADS-2003-0391; Savannah River Site: Aiken, SC, July 2003.

9. Click, D. R. Measured Coal Concentration in the Initial Tank Fifty One Sample by Thermogravimetric Analysis (TGA), Interoffice Memorandum SRT-ADS-2003-0392; Savannah River Site: Aiken, SC, July 2003.

10. Bibler, N. E.; Hay, M. S. Total and Soluble Sulfur in a Sample From Tank 40 (Sludge Batch 2) and a Composite of Samples from Tank 51 (Sludge Batch 3), WSRC-TR-2004-00092; Savannah River Site: Aiken, SC, March 2004.

11. Bibler, N. E.; Diprete, D. P.; Harbour, J. R. Determination of Reportable Radionuclides for DWPF Sludge Batch 2 (Macro Batch 3) (U), WSRC-TR-2002-00255; Savannah River Site: Aiken, SC, September 2002.

12. Culbertson, B. H. (DWPF Engineer). C-14 and I-129 in Tanks 40 and 51, E-Mail to N. E. Bibler, 10/7/03. Projections taken from WCS 1.5, Waste Characterization System, October 7, 2003.

13. Stone, M. E. SB2/SB3 Washing and Blending Recommendations (U), Interoffice Memorandum SRT-GPD-2003-00131; Savannah River Site: Aiken, SC, October 2003. 
14. Koopman, D. C. A Comparison of Rheology Data for Radioactive and Simulant Savannah River Site Waste (U), WSRC-TR-2004-00044; Savannah River Site: Aiken, SC, February 2004.

15. Herman, C. C. Chemical Process Cell Recommendation for Shielded Cells Qualification of Sludge Batch 3, Interoffice Memorandum SRT-GPD-2003-00111; Savannah River Site: Aiken, SC, September 2003.

16. Herman, C. C.; Koopman, D. C.; Best, D. R.; Snyder, T. K.; Williams, M. F. Sludge Batch 3 Simulant Flowsheet Studies: Final Phase SRAT/SME Results, WSRC-TR-2003-00422; Savannah River Site: Aiken, SC, September 2003.

17. Jantzen, C. M.; Koopman, D. C.; Herman, C. C.; Pickett, J. B.; Zamecnik, J. R. Electron Equivalence Model for Controlling REDuction/OXidation (REDOX) Equilibrium During High Level Waste (HLW) Vitrification, WSRC-TR-2003-00126; Savannah River Site: Aiken, SC, May 2003.

18. Edwards, T. B.; Harbour, J. R. The Sensitivity of the Shielded Cells' Acid Addition Strategy to Measurement Uncertainties, Interoffice Memorandum SRT-SCS-2003-00037; Savannah River Site: Aiken, SC, September 2003.

19. Pareizs, J. M. Run Plan for the SRAT 2 and Subsequent SME Sludge Batch 3 Confirmation Run in the SRTC Shielded Cells Facility; WSRC-RP-2003-01022; Savannah River Site: Aiken, SC, October 2003.

20. Peeler, D. K.; Edwards, T. B. Frit Recommendation for SB3 HLC Runs; Interoffice Memorandum SRT-GPD-2003-00134; Savannah River Site: Aiken, SC, October 2003.

21. Office of Environmental Restoration and Waste Management, Waste Acceptance Product Specifications for Vitrified High-Level Waste Forms, USDOE Document DOE/EM-0093, Rev. 2, December 1996.

22. "Standard Test Methods for Determining Chemical Durability of Nuclear, Hazardous, and Mixed Waste Glasses and Multiphase Glass Ceramics: The Product Consistency Test (PCT)", ASTM Test C1285-02, pp. 673-695 in 2002 Annual Book of ASTM Standards, Vol. 12.01, Philadelphia, PA, 2002.

23. Brown, K. G.; Postles, R. L. SME Acceptability Determination for DWPF Process Control, WSRCTR-95-0364, Rev. 3; Savannah River Site: Aiken, SC, February 1996.

24. Smith, G. L. Characterization of Analytical Reference Glass 1 (ARG-1), PNNL-8992; Pacific Northwest National Laboratory: Richland, WA, December 1993.

25. Jantzen, C. M.; Bibler N. E.; Beam D. C.; Crawford C. L.; and Pickett M. A. Characterization of the Defense Waste Processing Facility (DWPF) Environmental Assessment (EA) Glass Standard Reference Material (U); WSRC-TR-92-346, Rev. 1; Savannah River Site: Aiken, SC, 1993.

26. Mellinger, G. B.; Daniel, J. L. Approved Reference and Testing Materials For Use in Nuclear Waste Management Research and Development Programs; PNL-4955-2, Pacific Northwest National Laboratory: Richland, WA, 1984. 
WSRC-TR-2004-00050

Revision 0

27. Rios-Armstrong, M. A. SME Acceptability for Sludge Batch 3 (SB3) Shielded Cells Run (U);

Interoffice Memorandum CBU-WSE-2004-00028; Savannah River Site: Aiken, SC, February 2004. 
WSRC-TR-2004-00050

Revision 0

This page intentionally left blank. 


\subsection{ACKNOWLEDGEMENTS}

The authors would like to acknowledge the excellent support of the SRTC Shielded Cells technicians and supervision. Their flexibility, patience, and expertise in remotely processing this sludge were invaluable to the completion of this task. 
WSRC-TR-2004-00050

Revision 0

This page intentionally left blank. 
WSRC-TR-2004-00050

Revision 0

\section{APPENDIX A. OUTLINE OF ANALYTICAL METHODS}




\section{WSRC-TR-2004-00050 \\ Revision 0}

Densities of slurry and supernate - Triplicate analysis of the slurry samples and filtered supernate samples were accomplished in the following manner. Sealed pipette tips were calibrated by weighing the pipette tips empty, filling them with water and weighing again. The temperature of the water was noted and used to obtain the density of the water from reference sources. The volume of each pipette tip was obtained by dividing the measured weight of the water by the density. Each pipette tip was labeled for traceability. The calibrated pipettes were then used in the shielded cells with radioactive supernate and sludge slurry samples. For both the slurry and supernate, three replicate measurements were done. In each measurement, an empty pipette tip was weighed, filled with slurry or supernate and then re-weighed. The measured sample weight was then divided by the calibrated volume of the pipette tip to obtain the density.

Weight percent solids of slurry and supernate - triplicate analysis of a standard (a solution of a known concentration of $\mathrm{NaCl}$ ), the slurry samples and filtered supernate were accomplished using Analytical Development Section (ADS) procedure 2284 and in the following manner. Clean and dry polymethylpentene (PMP) beakers were labeled with identifying numbers and weighed. Approximately $3 \mathrm{~mL}$ of supernate, slurry or standard solution $(15 \mathrm{wt} \% \mathrm{NaCl})$ was added to separate pre-weighed beakers. The samples were dried in the oven at $115^{\circ} \mathrm{C}$ for at least 8 hours, removed, and allowed to cool for 10-15 minutes and re-weighed. The drying and weighing cycles continued until consecutive weights for each vessel did not vary by more than $0.01 \mathrm{~g}$. The weigh percent solids is [the last dry weight - empty weight $] /[\text { full weight - empty weight }]^{*} 100$. The weight percent solids on the slurry sample is designated as total solids, and the weight percent solids in the supernate is designated as dissolved solids. The insoluble solids and soluble solids were calculated according to the following equations:

$$
W_{i s}=\frac{W_{t s}-W_{d s}}{100-W_{d s}} \cdot 100 \text { and } W_{s s}=W_{t s}-W_{i s}
$$

where,

$W_{t s}=$ weight percent solids in slurry (weight percent total solids)

$W_{d s}=$ weight percent solids in supernate (weight percent dissolved solids)

$W_{i s}=$ weight percent insoluble solids in slurry

$W_{s s}=$ weigh percent soluble solids in the supernate.

Anion analysis of supernate - Triplicate analysis was done on filtered supernate samples. Three shielded polyethylene bottles were weighed and de-ionized water was added using a calibrated pipette to the bottle and the bottle was re-weighed. The bottles were taken into the shielded cells, weighed, and 0.5 to $2 \mathrm{~mL}$ of sample supernate was added using a calibrated pipette and finally the bottles were weighed again. The total amount of supernate added to the bottles was adjusted to make approximately a $10 \mathrm{X}$ or $20 \mathrm{X}$ dilution of the supernate. The samples were submitted for ion chromatography.

Elemental analysis of supernate - Triplicate analysis was done on filtered supernate samples. Three shielded polyethylene bottles were weighed and de-ionized water was added using a calibrated pipette to the bottle and the bottle was re-weighed. Then, $0.5 \mathrm{~mL}$ of nitric acid was added and the bottles were reweighed. The bottles were taken into the shielded cells, weighed, and 0.5 to $2 \mathrm{~mL}$ of sample supernate was added using a calibrated pipette and finally the bottles were weighed again. The total amount of supernate added to the bottles was adjusted to make approximately a $10 \mathrm{X}$ or $20 \mathrm{X}$ dilution of the supernate. The samples were submitted for ICP-ES.

Elemental analysis of total solids - Dried slurry solids were digested using two different types of dissolution (Aqua Regia and Sodium Peroxide Fusion) and from each dissolution, four samples were submitted for ICP-ES. ADS procedure 2226 was used for the aqua regia dissolutions and ADS procedure 
2502 was used for the sodium peroxide fusion dissolutions. The aqua regia dissolutions were also submitted for ICP-MS.

Total inorganic and organic carbon (TIC and TOC) - Triplicate analysis of TIC and TOC was done. To three shielded bottles each containing 10 grams of de-ionized water was added $\sim 0.15 \mathrm{~g}$ of well mixed radioactive slurry. The bottles were removed from the shielded cells and submitted for TOC and TIC analysis using a high temperature TOC analyzer.

Total base of slurry - Triplicate analysis of total base was done. This was determined via an inflection end point acid titration to $\mathrm{pH} 7$.

Oxalate content of slurry - Triplicate analysis of slurry was accomplished in the following manner. For each sample, an empty weigh cup was weighed and $\sim 1 \mathrm{~g}$ of radioactive slurry was added into the measuring cup and it was re-weighed. The sample weight was obtained by the difference. $2 \mathrm{~mL}$ of $\mathrm{HCl}$ was then added and the cup was swirled. $2 \mathrm{~mL}$ of $\mathrm{HNO}_{3}$ was added and the contents of the cup were swirled again. The contents of the cup were then diluted to either $100 \mathrm{~mL}$ or $250 \mathrm{~mL}$ in a volumetric flask. The resulting solution was analyzed by ion chromatography (IC).

Coal content of slurry - Triplicate analysis of coal in the slurry was accomplished in the following manner. For each sample, $\sim 30 \mathrm{~g}$ of the slurry was weighed out into a weighing cup which was then transferred to a $125 \mathrm{~mL}$ bottle. The slurry was then diluted up with de-ionized (DI) water to $125 \mathrm{~mL}$. A mesh screen (400 mesh) was put on top of a large polyethylene bottle and the contents of the $125 \mathrm{~mL}$ bottle was poured through the screen. The solids collected on the screen were washed with copious amounts of DI water and rinsed with $\sim 50 \mathrm{~mL}$ of $6 \mathrm{M} \mathrm{HNO}_{3}$. The solids collected were transferred to a polyethylene bottle and submitted for thermogravimetric analysis (TGA). 
WSRC-TR-2004-00050

Revision 0

This page intentionally left blank. 
WSRC-TR-2004-00050

Revision 0

APPENDIX B. TANK FARM PLANNING SPREADHSEET 


\section{WSRC-TR-2004-00050}

\section{Revision 0}

\begin{tabular}{|c|c|c|c|c|c|c|c|c|c|c|c|c|c|c|c|c|}
\hline & \begin{tabular}{|l|} 
Tk 51 \\
after \\
Transfer \\
7-51-4
\end{tabular} & Decant 4 & \begin{tabular}{|l} 
Tk 51 \\
after \\
Decant 4
\end{tabular} & $\begin{array}{l}\text { Tk } 51 \\
\text { after } \\
\text { Decant 7B }\end{array}$ & Add Pu & $\begin{array}{l}\text { Tank } 51 \\
\text { after add } \\
\text { Pu }\end{array}$ & Decant 5 & \begin{tabular}{|l} 
Tk 51 after \\
Decant 5
\end{tabular} & $\begin{array}{l}\text { Add } \\
\text { NaNO2 } \\
\text { for Np }\end{array}$ & \begin{tabular}{|l|} 
Tank 51 \\
after \\
NaNO2 \\
Add \\
\end{tabular} & $\begin{array}{l}\text { Transfer } \\
\text { to Tank 40 }\end{array}$ & \begin{tabular}{|l} 
Tank 51 \\
after 51-40- \\
1
\end{tabular} & \begin{tabular}{|l} 
Tank 40 \\
Initial \\
Condition
\end{tabular} & \begin{tabular}{|l} 
Tank 40 \\
after $51-40-$ \\
1
\end{tabular} & Add Np & \begin{tabular}{|l} 
Tank 40 \\
after add \\
$\mathrm{Np}$
\end{tabular} \\
\hline Initial tank Level & \begin{tabular}{|l}
291.34 \\
\end{tabular} & & 219.34 & 219 & & \begin{tabular}{|r|}
226.4 \\
\end{tabular} & & \begin{tabular}{|r|}
131.20 \\
\end{tabular} & & \begin{tabular}{|r|}
138.0 \\
\end{tabular} & & 10 & 0 & 128 & & $\begin{array}{r}133.2 \\
\end{array}$ \\
\hline liquid volume (gal) & 985509 & 249800 & 735709 & 735709 & 24299 & 760008 & 334000 & 426008 & 24000 & 450008 & 417407 & 32601 & 0 & 417407 & 18064 & 435471 \\
\hline sludge volume (gal) & 34181 & 0 & 34181 & 34181 & 315 & 34496 & 0 & 34496 & & 34496 & 31997 & 2499 & 0 & 31997 & & 31997 \\
\hline $\begin{array}{l}\text { sludge interface level est. at } \\
\text { time of decant }\end{array}$ & 107.0 & 107.0 & 107.0 & 107.0 & & 107.0 & 107.0 & 107.0 & & 107.0 & & 10 & & & & \\
\hline Decant tank Level & & 136.00 & & & & & 136 & & & 136 & & $w t \%$ IS $=$ & & 16.74 & & 16.08486 \\
\hline Transfer Volume & & 249800 & & & & & 334000 & & & & & $\mathrm{~kg}$ solid $=$ & 0 & 342012 & & 342012 \\
\hline IW Volume & & & & Canyon NO2 & 0 & & & & & & & alt\%IS & & 16.73 & & \\
\hline \begin{tabular}{|l|} 
Washwater Volume \\
\end{tabular} & & & & post flush & 5647.6 & & & {$[6 \mathrm{~b}=2.463 \mathrm{E} 6]$} & & & & altkgIS(20\%) & 0 & 342012 & 5000 & 342012 \\
\hline Additional NO2 Soln, gal & & NO2/NO3= & 1.666667 & TF NO2 & 0 & & & moles $\mathrm{Na}=$ & 24000 & & & alt\%IS(20\%) & assume $20 \%$ & 16.74 & -12752 & 16.08 \\
\hline Additional Volume, gal & & & & $\mathrm{NaOH}$ & 10.85 & & & $2.1027 \mathrm{E}+06$ & & & & Total SB3 Na & $3.0853 \mathrm{E}+06$ & [Case 6B is & $3.221 \mathrm{E} 6]$ & \\
\hline SpG & 1.0600 & 1.0600 & 1.0600 & 1.0600 & 1.1537 & 1.0630 & 1.0630 & 1.0630 & 1.3200 & 1.0767 & 1.0767 & 1.0767 & 1.0352 & 1.0767 & 1.2171 & 1.0825 \\
\hline $\mathrm{Na}$ & 1.2300 & 1.2300 & 1.2300 & 1.2300 & 3.5450 & 1.3040 & 1.3040 & 1.3040 & 7.6500 & 1.6425 & 1.6425 & 1.6425 & 0.4980 & 1.6425 & 4.2083 & 1.7489 \\
\hline NO2 & 0.3250 & 0.3250 & 0.3250 & 0.3250 & 0.0000 & 3146 & 3146 & 0.3146 & 7.6500 & \begin{tabular}{|l}
0.7058 \\
\end{tabular} & \begin{tabular}{|l|l|}
0.7058 \\
\end{tabular} & 0.7058 & 0.1960 & \begin{tabular}{|l|}
0.7058 \\
\end{tabular} & 0.0000 & 0.6765 \\
\hline NO3 & 0.1950 & 0.1950 & 0.1950 & 0.1950 & 3.2910 & 0.2940 & 0.2940 & 0.2940 & 0.0000 & 0.2783 & 0.2783 & 0.2783 & 0.0765 & 0.2783 & 3.3403 & 0.4053 \\
\hline $\mathrm{OH}$ & 0.2610 & 0.2610 & 0.2610 & 2610 & 0.2502 & 0.2607 & 0.2607 & 0.2607 & 0.0000 & 0.2468 & 0.2468 & 0.2468 & 0.1100 & 0.2468 & 0.8680 & 0.2725 \\
\hline $\mathrm{Cl}$ & 0.0011 & 0.0011 & 0.0011 & 0.0011 & 0.0000 & 0.0011 & 0.0011 & 0.0011 & 0.0000 & 0.0010 & 0.0010 & 0.0010 & 0.0059 & 0.0010 & 0.0000 & 0.0010 \\
\hline $\mathrm{SO} 4$ & 0.0201 & 0.0201 & 0.0201 & 0.0201 & 0.0000 & 0.0195 & 0.0195 & 0.0195 & 0.0000 & 0.0184 & 0.0184 & 0.0184 & 0.0130 & 0.0184 & 0.0000 & 0.0177 \\
\hline $\mathrm{F}$ & 0.0160 & 0.0160 & 0.0160 & 0.0160 & 0.0000 & 0.0155 & 0.0155 & 0.0155 & 0.0000 & 0.0147 & 0.0147 & 0.0147 & 0.0035 & 0.0147 & 0.0000 & 0.0141 \\
\hline $\mathrm{CO} 3$ & 0.0150 & 0.0150 & 0.0150 & 0.0150 & 0.0000 & 0.0145 & 0.0145 & 0.0145 & 0.0000 & 0.0137 & 0.0137 & 0.0137 & 0.1700 & 0.0137 & 0.0000 & 0.0132 \\
\hline AlO2-2 & 0.0492 & 0.0492 & 0.0492 & 0.0492 & 0.0000 & 0.0476 & 0.0476 & 0.0476 & 0.0000 & 0.0451 & 0.0451 & 0.0451 & 0.0100 & 0.0451 & 0.0000 & 0.0432 \\
\hline C2O4-2 & 0.0271 & 0.0271 & 0.0271 & 0.0271 & 0.0000 & 0.0262 & 0.0262 & 0.0262 & 0.0000 & 0.0248 & 0.0248 & 0.0248 & 0.0054 & 0.0248 & 0.0000 & 0.0238 \\
\hline PO4-3 & 0.0003 & 0.0003 & 0.0003 & 0.0003 & 0.0000 & 0.0003 & 0.0003 & 0.0003 & 0.0000 & 0.0003 & 0.0003 & 0.0003 & 0.0053 & 0.0003 & 0.0000 & 0.0003 \\
\hline $\mathrm{K}$ & 0.0055 & 0.0055 & 0.0055 & 0.0055 & 0.0000 & $\begin{array}{l}0.0053 \\
\end{array}$ & $\begin{array}{l}0.0053 \\
\end{array}$ & 0.0053 & $\begin{array}{l}0.0000 \\
0.00\end{array}$ & 0.0050 & 0.0050 & 0.0050 & 0.0129 & $\begin{array}{l}0.0050 \\
0.000\end{array}$ & 0.0000 & 0.0048 \\
\hline
\end{tabular}


WSRC-TR-2004-00050

Revision 0

APPENDIX C. PU/U/GD AND NP STREAMS USED IN SRTC SLUDGE BATCH 3 QUALIFICATION 
WSRC-TR-2004-00050

Revision 0

Preparation and Composition of Pu/U/Gd Stream Used in SRTC Sludge Batch 3 Preparation from M. R. Bronikowski, SRTC Actinide Technology Section

Following is an outline of the preparation of an H Canyon Tank 16.3 sample using an H Canyon Tank 12.1 sample.

1) Solutions for $\mathrm{Pu} / \mathrm{Gd} / \mathrm{U}$ makeup for neutralization

12.1 solution from Customer Sample report 24-July-2003 ID\# 200293849

density 1.1962

$0.822 \mathrm{~g} / 1 \mathrm{Pu}, 0.133 \mathrm{~g} / \mathrm{l} \mathrm{U}, \mathrm{Gd} 1.3 \mathrm{~g} / \mathrm{l}$

$6.035 \mathrm{M}$ acid

isotopics

\begin{tabular}{llllll}
\hline $\mathrm{Pu}$ & $\mathrm{wt} \%$ & $\mathrm{U}$ & $\mathrm{wt} \%$ & $\mathrm{Gd}$ & $\mathrm{wt} \%$ \\
\hline 238 & 0.046 & 234 & 0.096 & 152 & 0.19 \\
239 & 93.268 & 235 & 5.530 & 154 & 2.10 \\
240 & 6.362 & 236 & 0.082 & 155 & 14.49 \\
241 & .216 & 238 & 94.293 & 156 & 20.19 \\
242 & .109 & & & 157 & 15.59 \\
& & & & 158 & 24.99 \\
& & & & 160 & 22.45 \\
\hline
\end{tabular}

12.1 solution analyzed

$0.979 \mathrm{~g} / \mathrm{Pu}$ (high background) remeasured $\mathrm{w} / \mathrm{u}$ in solution is 0.81 so will use above $\mathrm{Pu}$

$0.191 \mathrm{~g} / \mathrm{l} \mathrm{U}$ ICP-es 3 measurements will use

$1.400 \mathrm{~g} / \mathrm{l} \mathrm{Gd}$ ICP-es measurements will use

5.53 M free acid but $6.0 \mathrm{M}$ standard sent with was $5.43 \mathrm{M}$ so will use the $6.035 \mathrm{M}$ above

U solution DU (from Kyser \#10014589, F-1-5A Du, 1Du-1 Special 7/18/97 211-8H)

308g/1 U ICP-es for U assume low acid 0.67M as is a U product (Lims\# 300199857-58)

Acid 69.5\% assayed $\mathrm{HNO}_{3}$

2) Makeup and neutralization on $8 / 27 / 03$, moved $8 / 28 / 03$, added $93 \mathrm{ml} 8 / 29 / 03$ to tank 51 sample

$255 \mathrm{ml}$ of 12.1 solution added $1.7 \mathrm{ml}$ of DU

took half of solution $127.5 \mathrm{ml}$ added $2.37 \mathrm{ml}$ of $69.5 \% \mathrm{HNO}_{3}$ (acid to go to $6.3 \mathrm{M}$ )

Neutralized by adding $54.5 \mathrm{ml}$ of wt $50 \% \mathrm{NaOH}$ with stirring and keeping $<50^{\circ} \mathrm{C}$

Makeup calcs.

$\mathrm{U} \quad \underline{0.191 \mathrm{~g} / 1(255 \mathrm{ml} 12.1)+1.7 \mathrm{ml}(308 \mathrm{~g} / 1 \mathrm{U})}=\underline{572.305}=2.229 \mathrm{~g} / 1 \mathrm{U}$

$255 \mathrm{ml}+1.7 \mathrm{ml} 256.7$

$\mathrm{Pu} \quad \frac{0.822 \mathrm{~g} / \mathrm{l}(255 \mathrm{ml} \mathrm{12.1})}{255 \mathrm{ml}+1.7 \mathrm{ml}}=\frac{209.61}{256.7}=0.8165562 \mathrm{~g} / \mathrm{Pu}$ 
both were then diluted with $2.37 \mathrm{ml}$ acid so $\mathrm{x} 127.5 \mathrm{ml} /(127.5 \mathrm{ml}+2.37)=0.9817509$

so solution to be neutralized is

$2.19 \mathrm{~g} / 1 \mathrm{U}, 0.80 \mathrm{~g} / \mathrm{l} \mathrm{Pu}$, and $6.3 \mathrm{M}$ acid Note here that B is absent but would be present from 16.3 and Pu conc. is a little lower than the expected $0.95 \mathrm{~g} / 1$ mixed total but the $\mathrm{U}$ is correct.

\begin{tabular}{|l|l|l|l|l|}
\hline & Free Acid $(\mathrm{M})$ & $\mathrm{Pu}(\mathrm{g} / \mathrm{l})$ & $\mathrm{U}(\mathrm{g} / \mathrm{l})$ & $\mathrm{Gd}(\mathrm{g} / \mathrm{l})$ \\
\hline Made up 12.1 & 6.3 & 0.80 & 2.19 & 1.40 \\
\hline $\begin{array}{l}\text { Mixed total } \\
(7 / 7 / 03 \text { calc. })\end{array}$ & 6.31 & 0.95 & 2.189 & 1.34 \\
\hline
\end{tabular}

Other elements at $>.1 \mathrm{~g} / 1$ concentration

\begin{tabular}{|c|c|c|c|c|}
\hline element & $\mathrm{g} / 1$ in 12.1 & $\begin{array}{l}\text { 12.1 dilute with } \mathrm{U} \\
\text { (dil factor) }\end{array}$ & $\begin{array}{l}1 / 2 \text { diluted with acid } \\
\text { (dil factor) }\end{array}$ & $\begin{array}{l}\mathrm{g} / \mathrm{l} \text { in solution to } \\
\text { be neutralized }\end{array}$ \\
\hline $\mathrm{Gd}$ & 1.436 & $255 \mathrm{ml} / 256.7 \mathrm{ml}$ & $127.5 / 129.87$ & 1.400 \\
\hline $\mathrm{Al}>$ & 0.830 & $(0.9933774)$ & $(0.9817509)$ & $>0.809$ \\
\hline $\mathrm{Ca}$ & 0.388 & " & " & 0.378 \\
\hline $\mathrm{Fe}$ & 0.260 & “" & “ & 0.254 \\
\hline $\mathrm{Mg}$ & 0.694 & “" & “ & 0.677 \\
\hline $\mathrm{Na}>$ & 0.100 & “" & “ & $>0.098$ \\
\hline $\mathrm{Si}>$ & 0.102 & “" & “" & $>0.099$ \\
\hline
\end{tabular}

$>$ values have some minor amount associated with the $\mathrm{U}$ solution that have not been added in

\section{Neutralization calcs.}

Neutralization is to $0.3 \mathrm{M} \mathrm{OH}^{-}$excess was obtained by adding $54.5 \mathrm{ml}$ of $50 \% \mathrm{wt} \mathrm{NaOH}$ to the above solution. (Calc includes neutralizing $\mathrm{U}, \mathrm{Pu}, \mathrm{Gd}, \mathrm{Mg}, \mathrm{Ca}$, and $\mathrm{Al}$ ( $1 / 2$ of 1.71 moles acid) and raising full solution to $0.3 \mathrm{M}$ )

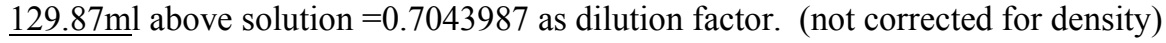

$184.37 \mathrm{ml}$ final volume

so final added $\mathrm{Pu}$ is $0.56 \mathrm{~g} / 1 * 0.093 \mathrm{~L}=0.052 \mathrm{~g}$

final $\mathrm{U}$ is $0.143 \mathrm{~g}$

final $\mathrm{Gd}$ added is $0.092 \mathrm{~g}$

final $\mathrm{Na}$ added is $0.0545 \mathrm{~L} * 19 \mathrm{~mol} / 1 * 40 \mathrm{~g} / \mathrm{mol}^{*} 93 \mathrm{ml} / 184.37 \mathrm{ml}=20.89 \mathrm{~g} \mathrm{Na}$

final $\mathrm{NO}_{3}$ added $=(1 / 2) * 1.71 \mathrm{moles} * 93 \mathrm{ml} / 184.37=0.431$ moles $\mathrm{NO}_{3}$

Experimentally measured density of neutralized slurry is $1.285 \mathrm{~g} / 1$ 
WSRC-TR-2004-00050

Revision 0

Composition Neptunium Stream Used in SRTC Sludge Batch 3 Preparation from D. D. Walker, SRTC Waste Processing Technology Section

WSRC-TR-2003-00144, Rev. 0
Page 13 of 40

TABLE II. Composition of Neutralized Neptunium Slurry

Solids Composition

After drying at $23^{\circ} \mathrm{C}$ :

Yield of damp solids: $\quad 13( \pm 1)$ wt \%

Phases identified

by X-ray diffraction: magnetite, sodium nitrate

After drying to constant weight at $115^{\circ} \mathrm{C}$ (approx. 4 hours):

Weight loss on drying at $115^{\circ} \mathrm{C} \quad 54 \pm 3 \%$

Component Concentration Component Concentration

(wt \%)

$1.6 \pm 0.1$

$\begin{array}{llll}\mathrm{Fe} & 29.0 \pm 2.4 & \mathrm{~S} & 2.4 \pm 0.2\end{array}$

$\begin{array}{llll}\text { Mn } & 0.16 \pm 0.01 & \mathrm{~Np}-237 & 1.03 \pm 0.07\end{array}$

Solution Composition

Component Concentration Component Concentration

$\underline{(\mathrm{M})} \underline{(\mathrm{mg} / \mathrm{L})}$

$\begin{array}{llll}\mathrm{OH}^{-} & 0.60 \pm 0.11 & \mathrm{Cr} & 10.4 \pm 0.6\end{array}$

Nitrate $\quad 4.48 \pm 0.22 \quad \mathrm{Ni} \quad<0.2$

Sulfate $\quad 0.84 \pm 0.04 \quad \mathrm{Mn} \quad<0.1$

$\begin{array}{llll}\mathrm{Na} & 6.6 \pm 0.2 & \mathrm{Ca} & 0.53 \pm 0.10\end{array}$

Al $0.109 \pm 0.008 \quad \mathrm{Zn} \quad 0.46 \pm 0.16$

$\mathrm{Zr}<0.3$

Np-237 $\quad 1.8 \pm 0.6$

Total U $\quad 9 \pm 2$

U-234 $0.7( \pm 0.2)$

U-235 $\quad 4.0( \pm 1.0)$

$\mathrm{U}-236 \quad 1.2( \pm 0.3)$

U-238 $\quad 3.3( \pm 0.7)$

$\begin{array}{ll}\text { Component } & \frac{\text { Concentration }}{(\mathbf{d} / \mathbf{m} / \mathbf{m L})} \\ \text { Cs-137 } & 1.38(0.04) \times 10^{6} \\ \text { Cs-134 } & 8.0( \pm 0.4) \times 10^{3}\end{array}$

Other

Density $1.322 \mathrm{~g} / \mathrm{mL}$

*Listed uncertainties are the standard deviation of measurements from two neutralization

experiments. Analytical uncertainties are nominally $\pm 10 \%$. 
WSRC-TR-2004-00050

Revision 0

APPENDIX D. ACID CALCULATION SPREADSHEET FOR THE SECOND SRAT CYCLE 
WSRC-TR-2004-00050

\section{Revision 0}

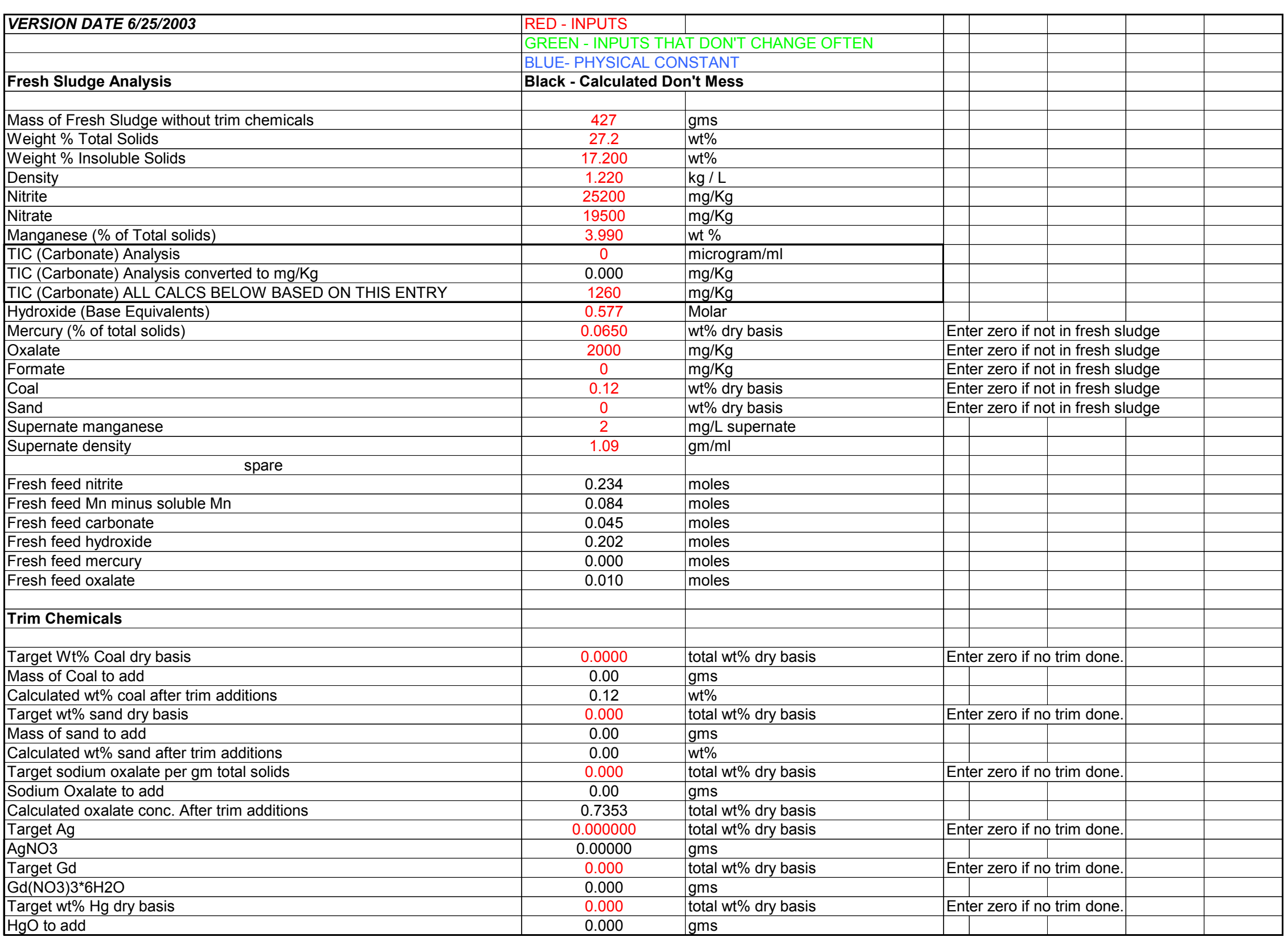


WSRC-TR-2004-00050

Revision 0

\begin{tabular}{|c|c|c|c|c|c|c|}
\hline Calculated total $\mathrm{wt} \% \mathrm{Hg}$ dry basis & 0.0650 & wt $\%$ dry basis & & & & \\
\hline Target Pd metal content & 0.00000 & total wt $\%$ dry basis & \multicolumn{2}{|c|}{ Enter zero if no trim done. } & & \\
\hline Wt \% Pd in reagent solution & 15.2700 & wt $\%$ in solution & & & & \\
\hline $\mathrm{Pd}(\mathrm{NO} 3) 2^{*} \mathrm{H} 2 \mathrm{O}$ & 0.000 & gms of solution & & & & \\
\hline Target Rh metal content & 0.00000 & total $w t \%$ dry basis & \multicolumn{2}{|c|}{ Enter zero if no trim done. } & & \\
\hline $\mathrm{Wt} \% \mathrm{Rh}$ in reagent solution & 4.93 & wt $\%$ in solution & & & & \\
\hline $\mathrm{Rh}(\mathrm{NO} 3) 3^{*} 2 \mathrm{H} 2 \mathrm{O}$ & 0.000 & gms of solution & & & & \\
\hline Target Ru & 0.0000 & total wt $\%$ dry basis & \multicolumn{2}{|c|}{ Enter zero if no trim done. } & & \\
\hline Wt\% Ru RuCl3 reagent solids & 41.74 & wt $\%$ in solids & & & & \\
\hline $\mathrm{RuCl} 3$ & 0.000 & gms solid & & & & \\
\hline Total solids before trim addition & 116.1 & gms & & & & \\
\hline Total solids after trim addition & 116.14 & gms & & & & \\
\hline Total mass of trim chemicals added & 0.00 & gms & & & & \\
\hline Water to dilute trim chemicals and reduce total solids content & 0.00 & gms & \multicolumn{4}{|c|}{ Iterate water get desired initial total solids } \\
\hline DWPF sludge transfer flush water & 0.00 & gal & & & & \\
\hline Scaled DWPF flush water minus trim chemical water & 0.00 & gms & & & & \\
\hline Mass of trimmed sludge & 427.00 & gms & & & & \\
\hline Calculated wt $\%$ Total solids in trimmed sludge & 27.20 & wt $\%$ & & & & \\
\hline Sample Mass of Trimmed sludge & 0.00 & gms & & & & \\
\hline Mass of trimmed sludge reacted & 427.00 & gms & & & & \\
\hline Sample Removal Ratio as strart of SRAT & 1.0000 & & & & & \\
\hline & & & & & & \\
\hline \multicolumn{7}{|l|}{ Molecular Weights } \\
\hline Nitrite & 46.01 & $\mathrm{~g} / \mathrm{mole}$ & & & & \\
\hline Nitrate & 62.01 & $\mathrm{~g} / \mathrm{mole}$ & & & & \\
\hline Manganese & 54.94 & $\mathrm{~g} / \mathrm{mole}$ & & & & \\
\hline Carbonate & 60.01 & $\mathrm{~g} / \mathrm{mole}$ & & & & \\
\hline Mercury & 200.59 & $\mathrm{~g} / \mathrm{mole}$ & & & & \\
\hline Oxalate & 88.02 & $\mathrm{~g} / \mathrm{mole}$ & & & & \\
\hline Mercuric Oxide & 216.59 & $\mathrm{~g} / \mathrm{mole}$ & & & & \\
\hline Sodium Oxalate & 134.00 & $\mathrm{~g} / \mathrm{mole}$ & & & & \\
\hline Formate & 45.01 & $\mathrm{~g} / \mathrm{mole}$ & & & & \\
\hline Carbon & 12.01 & $\mathrm{~g} / \mathrm{mole}$ & & & & \\
\hline $\mathrm{Rh}(\mathrm{NO} 3) 3^{*} 2 \mathrm{H} 2 \mathrm{O}$ & 324.93 & $\mathrm{~g} / \mathrm{mole}$ & & & & \\
\hline $\mathrm{Rh}$ & 102.91 & $\mathrm{~g} / \mathrm{mole}$ & & & & \\
\hline $\mathrm{Gd}(\mathrm{NO} 3) 3^{*} 6 \mathrm{H} 2 \mathrm{O}$ & 451.36 & $\mathrm{~g} / \mathrm{mole}$ & & & & \\
\hline Gd & 157.25 & $\mathrm{~g} / \mathrm{mole}$ & & & & \\
\hline $\mathrm{Pd}(\mathrm{NO} 3) 2^{*} \mathrm{H} 2 \mathrm{O}$ & 246.42 & $\mathrm{~g} / \mathrm{mole}$ & & & & \\
\hline $\mathrm{Pd}$ & 106.4 & $\mathrm{~g} / \mathrm{mole}$ & & & & \\
\hline AgNO3 & 169.89 & $\mathrm{~g} / \mathrm{mole}$ & & & & \\
\hline $\mathrm{Ag}$ & 107.868 & $\mathrm{~g} / \mathrm{mole}$ & & & & \\
\hline \multicolumn{7}{|l|}{ Assumed Parameters } \\
\hline Percent of TRIM sodium oxalate which generates Base Equivalents & 100.00 & moles $\mathrm{OH}-/ 100$ moles Oxalate & & & & \\
\hline Conversion of Nitrite to Nitrate & 32.40 & moles NO3-/100 moles NO2- & & & & \\
\hline Destruction of Nitrite including SME cycle & 100.00 & $\%$ & & & & \\
\hline
\end{tabular}




\section{WSRC-TR-2004-00050}

\section{Revision 0}

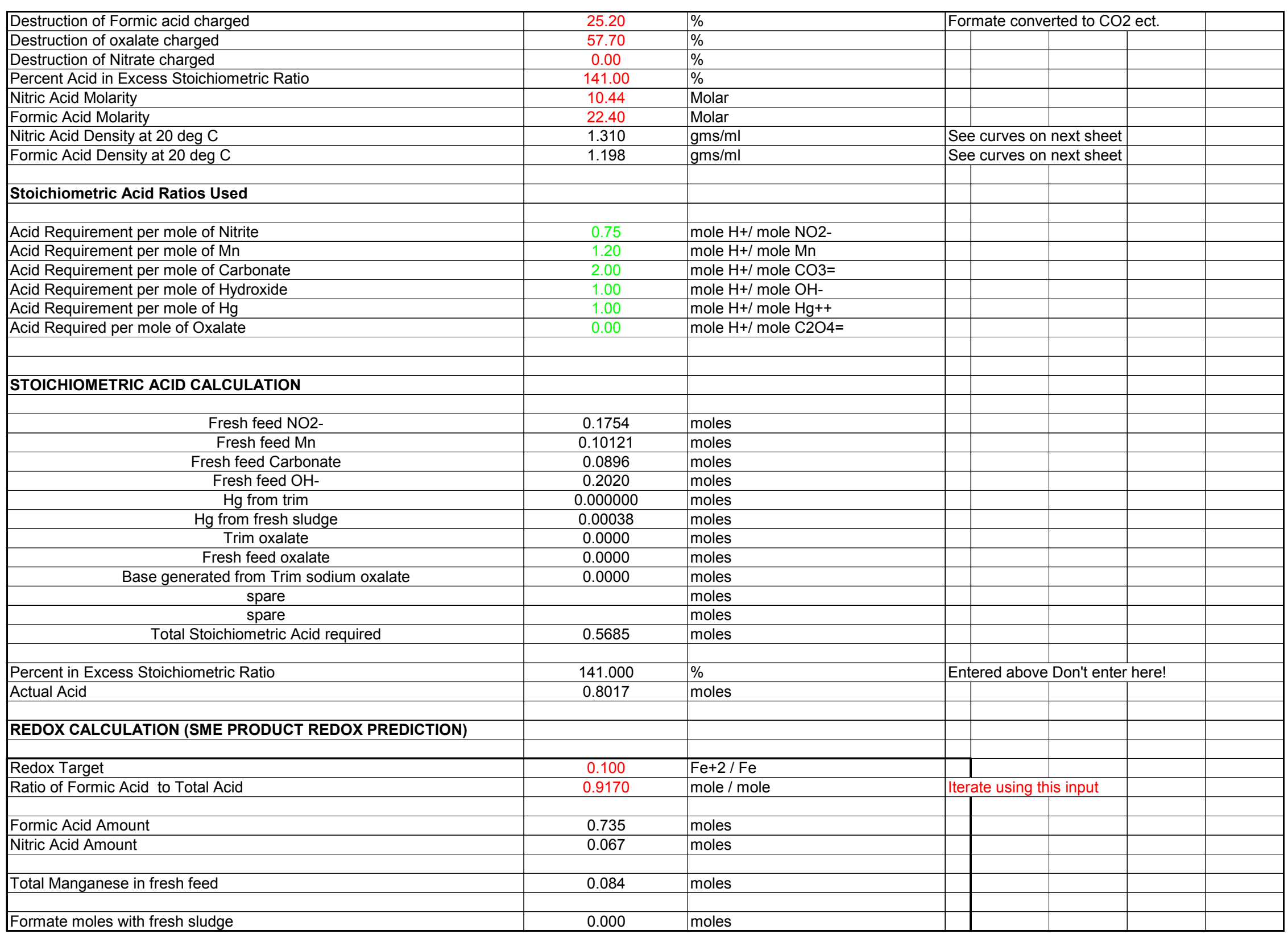


WSRC-TR-2004-00050

Revision 0

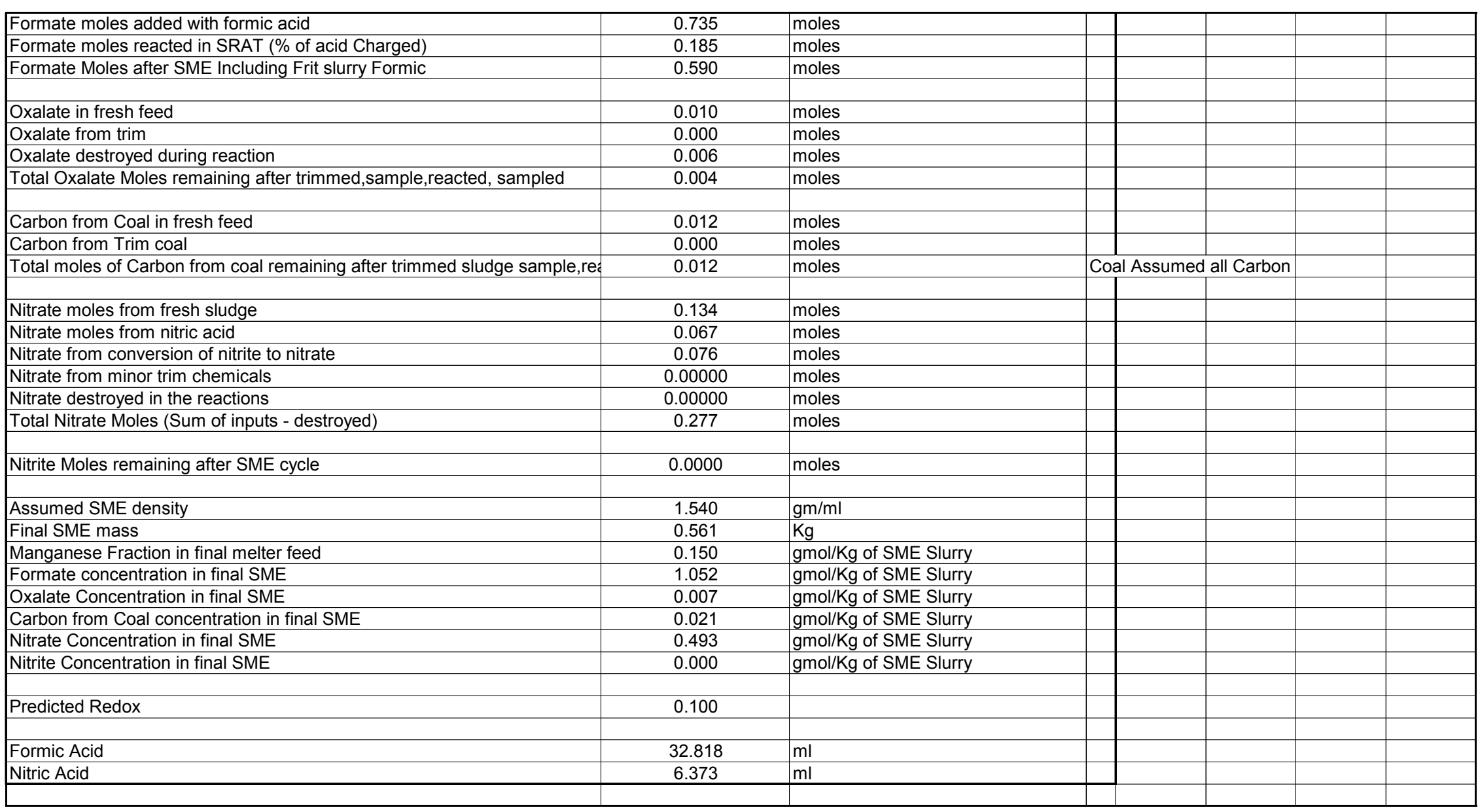


WSRC-TR-2004-00050

Revision 0

This page intentionally left blank. 
WSRC-TR-2004-00050

Revision 0

APPENDIX E. DESCRIPTION AND RESULTS OF THE FIRST SRAT CYCLE USING SB3 MATERIAL 


\section{WSRC-TR-2004-00050 \\ Revision 0}

An initial SB3 sludge SRAT cycle was performed before the final SB3 qualification SRAT/SME cycle discussed in the main text of this report. This appendix discusses a preliminary run, SRAT 1, including how it differed from the second (final) run, SRAT 2.

The initial SB3 SRAT run used $1230 \mathrm{~g}$ of the prepared SB3 sludge for qualification. The prepared SB3 sludge incorporated projected plutonium and neptunium additions in the tank farm. The initial SRAT cycle was conducted in a 4-L vessel, rather than a 1-L vessel as used in the second SRAT cycle. Purge air flow and acid addition rate were correspondingly higher in the first SRAT cycle to maintain prototypical conditions. The $1230 \mathrm{~g}$ of sludge did not fill the 4-L kettle to a depth greater than that covered by the heating mantle, making visual observation of the level extremely difficult. Most peripheral equipment was identical to that used in SRAT 2 (discussed in the main report). There were three differences. The SRAT-1 had no manometer, had a SRAT condenser with a different design, and was initially equipped with a $\mathrm{pH}$ probe.

Processing of the SRAT-1 sludge charge proceeded in the expected manner during heat-up, antifoam addition, nitric acid addition, and formic acid addition. Difficulties began to occur once the SRAT vessel contents were brought to boiling. A three hour outage was necessary to replace the agitator drive cable. The process was held at about $90^{\circ} \mathrm{C}$ during this time, and GC data was continuously taken. Only small quantities of condensate were collected initially, once boiling was established. This suggested that the power to the mantle was too low to obtain the equivalent of a $5000 \mathrm{lbs} . / \mathrm{hr}$ boil-up rate. Power was increased during de-watering to correct the low boil-up rate. The targeted mass of condensate was collected to return the system to approximately its initial fresh sludge volume. The SRAT was then put into reflux.

The temperature of the slurry during reflux was $1-2^{\circ} \mathrm{C}$ higher than expected or typically seen during labscale SRAT experiments. The slurry temperature continued to rise during the initial portion of the reflux period even when adjustments were made to decrease the power input. After the slurry temperature reached $107^{\circ} \mathrm{C}$, the camera in the cell was adjusted to obtain a better view of the mixing slurry. When this was done, the sludge level appeared to be very low and the agitator blade appeared to be partially exposed. Apparently, a significant and unexpected loss of volume had occurred during boiling, so the power to the heating mantle was turned off.

The SRAT vessel was examined and attempts were made to estimate the remaining volume. It was estimated that the volume in the vessel was about $525 \mathrm{ml}$. The volume should have been about $1200 \mathrm{ml}$. To bring the SRAT back to the target volume, $141 \mathrm{~g}$ of SRAT cycle condensate plus 500 grams of deionized water were added to the SRAT. An additional 450 grams of de-ionized water were added to offset projected losses during the remainder of the reflux period (based on projected boil-up rate and losses experienced). The SRAT was taken to a gentle boil (likely less than prototypical boil-up rate, but the rate was not measured) and the temperature and refluxing condensate were closely monitored to ensure that the chances of concentration were minimized. Slurry temperature was maintained at about $102^{\circ} \mathrm{C}$, which is typical for lab-scale SRAT runs. Reflux was completed to give a total reflux time of 12 hours including the time before the cycle was stopped and the time after the cycle was restarted. Samples were taken of the SRAT product for characterization. As mentioned in the main body of the report, some of the SRAT product was combined with frit to produce glass for composition and performance of the PCT.

During the concentration, hydrogen in the off-gas stream reached nearly 0.43 volume $\%$ before the heating mantle was turned off. The hydrogen concentration had been rising steadily prior to shutting off the mantle. Hydrogen generation produced a much lower concentration in the off-gas once the system was returned to boiling, $\sim 0.01$ volume $\%$. Due to this sudden rise, the off-gas data collected during this run was not believed to be representative of SB3 processing at $141 \%$ of the stoichiometric acid 
calculation. This drove the decision to repeat the SRAT cycle, as well as the uncertain anion destruction numbers.

Two primary equipment factors were isolated that either singly or in concert led to the difficulties in the first SRAT cycle. These were the choice for the SRAT condenser and the capacity of the off-gas tubing. The condenser required that condensate drain down a small diameter coiled tube against the upward flow of the non-condensable purge gas. The downstream off-gas tubing was adequately sized for the flow. However, several quick connectors in the line had much smaller internal diameters than the tubing itself. A section of tubing behind the Cells' wall was also not as large in diameter as the tubing that was visible.

It is believed that when the SRAT went to boiling, condensate began to collect inside the tube in the SRAT condenser. Some of the purge air was able to force its way through the condenser, since the GC continued to indicate changing process conditions. The effect of the restrictions in the off-gas line, however, caused the pressure to rise in the SRAT vessel. This pressure rise was sufficient to raise the boiling point by $4-5^{\circ} \mathrm{C}$. This would imply a pressure increase of about $0.17 \mathrm{Atm}$ for pure water. The actual pressure increase in the SRAT must have been less than this, since there was a boiling point elevation effect due to the soluble species in the supernate. Their concentrations were increased by roughly a factor of 2.3 while the volume decreased and the boiling temperature rose. Separating the two effects, temperature rise due to pressure and temperature rise due to increasing molarity, requires more data than is available. What is important is that there was some pressure increase as noted by the breaking of the seals on some of the SRAT components.

One significant secondary cause to the over-concentration of the SRAT contents was that the SRAT vessel plus accessories were not leak-tight. Steps were taken to minimize leaks, since this improves the dynamic response of off-gas concentration. Note also that the Shielded Cells and Aiken County Technical Laboratory (ACTL) SRAT vessels are not run under vacuum. Leakage is from the inside of the vessel to the surroundings, rather than from the surroundings into the vessel (like DWPF). This simplifies the small-scale test equipment, and is permissible since simulant tests are run in chemical hoods and the Shielded Cells tests are completely enclosed by the Cells ventilation system.

Vessel air leaks that are relatively insignificant at a positive pressure of $1 / 4-1 / 2$ inch water column in the SRAT can be problematic at 2-3 inches water column. The leak rate is proportional to the pressure difference between the vessel and the surroundings. The data indicate that water vapor was leaking at some rate comparable to the nominal boil-up rate target (equivalent to $\sim 5000 \mathrm{lbs}$. $/ \mathrm{hr}$ of water loss at DWPF-scale). Subsequent testing showed the importance of keeping the SRAT pressure near atmospheric pressure to control leakage. This was accomplished by replacing the restricted portions of the off-gas line and switching to a different condenser design.

The second SRAT run confirmed that the production of hydrogen is governed by concentration and temperature dependent quantities. Peak hydrogen generation in the second run was much lower than in the first run as expected. This expectation was developed as follows.

Hydrogen generation is a catalytic process related to the noble metals. Hydrogen generation is apparently driven by excess formic acid. The rate of hydrogen generation depends on a kinetic expression containing rate constants and concentrations. The rate constant(s) presumably depend linearly on the noble metal concentration(s). These were $\sim 2.3$ times greater during the peak hydrogen generation period than normal. It is quite likely that the rate of hydrogen generation depends on formate ion and/or formic acid molecule concentration raised to some power. These concentrations were similarly increased as the slurry volume shrunk. There was presumably also a shift between the relative amounts of formate ion and formic acid molecule related to $\mathrm{pH}$ and the equilibrium constant for dissociation of formic acid. Finally, there was a temperature increase associated with the higher pressure of about $5^{\circ} \mathrm{C}$. 
The best available data indicate that the temperature dependence of hydrogen generation is proportional to $\mathrm{e}^{-12,577 / \mathrm{T}},^{\dagger}$. A temperature increase of $5^{\circ} \mathrm{C}$ would be expected to produce a $55 \%$ increase in rate near $100^{\circ} \mathrm{C}$. If the hydrogen generation rate was simply proportional to a rate constant (function of noble metal concentration and temperature) multiplied by a total concentration, e.g. of formic acid molecules plus formate ions, raised to the second power, then the rate of hydrogen generation would be expected to have increased by $2.3 * 1.55 * 2.3$, or by a factor of approximately 8 . One 2.3 is for the noble metal effect and one is for the reduced volume effect on non-catalytic concentrations. Applying such corrections to the initial SRAT run GC data reduces the hydrogen peak from 0.43 volume $\%$ to about 0.05 vol. $\%$. This is in much closer agreement with, but is still double, the level seen in the second SRAT run $(0.023$ vol. $\%$ ). This partial reconciliation of the two hydrogen generation data sets also suggests that the kinetic reasoning used, while plausible, contains a few too many assumptions with respect to the actual form of the reaction kinetic expression.

The figure below gives the SRAT 1 hydrogen generation rate data in raw form in equivalent DWPF-scale $\mathrm{lbs} . / \mathrm{hr}$. It also gives an estimate of what the data would have looked like assuming the volume was falling linearly once boiling started, plus making a compensation through the Arrhenius rate constant temperature dependence for the elevated temperature. A first order dependence on the concentration of an arbitrary species in the slurry was assumed. The assumed rate expression took the form:

$-\frac{1}{V} \frac{d\left[\text { moles }_{\text {formate }+ \text { formic acid }}\right]}{d t}=k *\left[\text { concentration }_{\text {slurry species }}\right]^{2}$

with $k=k_{0} *(\Sigma[$ noble metals $]) * e^{-12577 / T}$

where

$V=$ volume

$k=$ rate constant

$k_{0}=$ pre-exponential factor

$T=$ absolute temperature

The molar hydrogen generation rate was assumed to by linearly proportional to the molar rate of loss of formate-formic acid.

$\frac{d\left(\text { moles }_{\mathrm{H}_{2}}\right)}{d t} \propto-\frac{d\left[\text { moles }_{\text {formate }+ \text { formic acid }}\right]}{d t}=k *\left[\text { concentration }_{\text {slurry species }}\right]^{2} * V$

or

$\frac{d\left(\text { moles }_{\mathrm{H}_{2}}\right)}{d t} \propto k_{0} *\left(\right.$ (moles $\left._{\text {noble metals }}\right) * e^{-12577 / T} *\left(\text { moles }_{\text {slurry species }}\right)^{2} / V^{2}$

where Temperature and Volume were the only quantities changing significantly with time on the righthand-side. Not factored in was the loss in the reactant that was occurring in reality. The SRAT 2 hydrogen generation rate data is shown for comparison with the raw and adjusted SRAT 1 hydrogen generation results in the figure below.

\footnotetext{
${ }^{\dagger}$ Hsu, C.W. and Ritter, J.A., Study on Hydrogen Evolution During Treatment of SRS High Level Radioactive Sludge Simulant with Formic Acid (U), WSRC-RP-92-270; Savannah River Site: Aiken, SC, August 1992.
} 


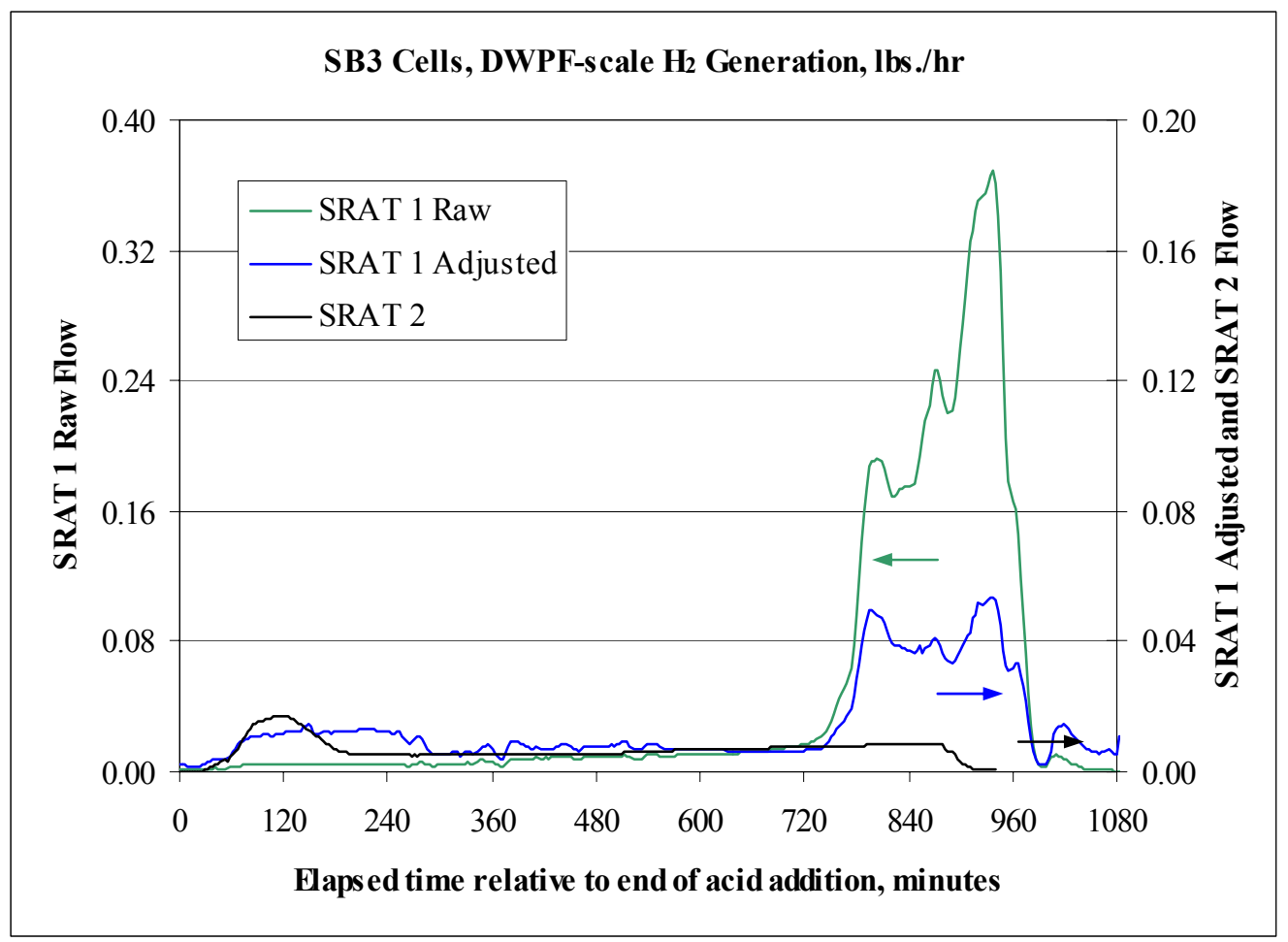

All of the hydrogen generation rate data is fairly comparable out to the 720 minute mark. The corrections for volume and temperature become more significant from then on. Note that the right-hand axis has only half the range of the left-hand axis. The maximum hydrogen generation rate observed in the first twelve hours actually came from the SRAT 2 initial peak at about 2 hours after acid addition.

Given the current understanding of hydrogen generation in waste sludge slurries, it was prudent to perform a second SRAT test to obtain off-gas data that were not impacted by the large volume changes. 
WSRC-TR-2004-00050

Revision 0

This page intentionally left blank. 
WSRC-TR-2004-00050

Revision 0

APPENDIX F. COMPARISON OF RADIOACTIVE AND SIMULANT SRAT/SME TESTING 


\section{WSRC-TR-2004-00050}

\section{Revision 0}

\section{E.1 Sludge Comparison}

Simulant flowsheet testing was conducted prior to the Shielded Cells demonstration of SB3 processing. The base SB3 simulant was initially prepared based on the High Level Waste database values for the insoluble solids and to match a very washed state. Additional chemicals were then added to the simulant to bring it to the projected composition for SB3. The table below compares the SB3 sludge as prepared and analyzed in the Shielded Cells to the SB3 simulant used in the final flowsheet runs in support of the Cells work. Simulant results correspond to the fully-trimmed starting sludge for the final two runs in the flowsheet testing, SB3A-19 and SB3A-20. Simulant results are an average of results from the two runs.

\section{Comparison of Results for the Stoichiometric Acid Calculation}

\begin{tabular}{|l|l|l|}
\hline Property & Cells Result & Simulant Result \\
\hline Wt. \% Total Solids & 27.2 & 21.6 \\
\hline Wt. \% Insoluble Solids & 17.2 & 11.7 \\
\hline Density, kg/L & 1.22 & 1.20 \\
\hline Base Equivalents, M, at pH 7 & 0.577 & 0.584 \\
\hline Nitrite ion, mg/kg slurry & 25,200 & 23,900 \\
\hline Nitrate ion, mg/kg slurry & 19,500 & 21,100 \\
\hline Total Inorganic Carbon, mg/kg slurry & 1,260 & 830 \\
\hline Wt. \% Mn in Total Solids & 3.99 & 3.26 \\
\hline Wt. \% Hg in Total Solids & 0.065 & 0.303 \\
\hline Stoichiometric Acid Requirement, moles/L & 1.624 & 1.405 \\
\hline
\end{tabular}

1. Acid requirement at $100 \%$ of the DWPF computational algorithm

The radioactive and simulant sludges were quite similar in their acid requirement inputs. This was partly due to the better analytical information available concerning the properties of Tank 7 waste, which constituted the bulk of SB3. The wt. \% insoluble solids target in the Cells was chosen after the simulant work was complete. Otherwise, the simulant work would have been done at a higher solids loading. The two major contributors to the stoichiometric acid requirement were base equivalents and nitrite ion concentration, which made up $66 \%$ of the total requirement. Excellent agreement was obtained with the simulant for these two properties.

Noble metals had been identified as critical to the successful processing of SB3 due to the high stoichiometric acid requirement and associated challenges in controlling the acid addition within the bounds of nitrite destruction and minimal hydrogen generation. The following table compares the quantity of noble metals present in the radioactive and simulant sludges. The final basis for comparison was chosen to be the mass of a noble metal present in a fixed volume of sludge slurry, i.e. the amount available for hydrogen generation in a typical batch. Simulant wt. \% results are calculated based on the mass of noble metal added directly to the SRAT as a trim chemical. They have been updated from the sludge prediction to reflect the $21.6 \mathrm{wt}$. \% total solids result $(22.21 \%$ expected $)$. 
Noble Metal Concentration Comparison

\begin{tabular}{|l|l|l|}
\hline & Cells Result & Simulant Result \\
\hline Wt. \% Total Solids & 27.2 & 21.6 \\
\hline Density, kg/L & 1.22 & 1.20 \\
\hline Wt. \% Ag & 0.0115 & 0.011 \\
\hline Wt. \% Pd & 0.00166 & 0.00185 \\
\hline Wt. \% Rh & 0.00712 & 0.00643 \\
\hline Wt. \% Ru & 0.0362 & 0.0328 \\
\hline $\mathrm{Ag}, \mathrm{mg} / \mathrm{L}$ & 38.2 & 28.5 \\
\hline $\mathrm{Pd}, \mathrm{mg} / \mathrm{L}$ & 5.51 & 4.80 \\
\hline $\mathrm{Rh}, \mathrm{mg} / \mathrm{L}$ & 23.6 & 16.7 \\
\hline $\mathrm{Ru}, \mathrm{mg} / \mathrm{L}$ & 120 & 85.1 \\
\hline
\end{tabular}

Data from the analysis of Tank 7 was used to determine an estimate for the noble metal concentrations in the insoluble solids for SB3 on a radionuclide-free basis. This was generally successful, as seen by a comparison between the weight percents in the above table. The simulant weight percents' would be higher than in the radioactive waste if the weight percent total solids were dropped to $21.5 \%$ in the Cells sludge. This would make the simulant bounding for noble metal effects, which is the generally desired situation.

The shift to a higher total solids loading in the Shielded Cells sludge slurry brought in additional noble metals. First, the weight percent insoluble solids were increased relative to the soluble solids. This raised the weight percent's of the noble metals in the total solids, since they are primarily present as insoluble species. Second, the higher weight percent total solids led to more insoluble solids in the final slurry on a $\mathrm{mg} / \mathrm{L}$ basis. This led to the Cells slurry having about $40 \%$ more $\mathrm{Rh}$ and $\mathrm{Ru}$ than the simulant on a $\mathrm{mg} / \mathrm{L}$ basis. A potentially mitigating factor during processing was the fact that radioactive sludge noble metals form within the insoluble solids matrix. Consequently, they are presumably more difficult to reduce to the catalytically active forms compared to the simulant noble metals.

In summary, there were two main differences between the radioactive and simulant starting sludges that could effect SRAT processing. These were the increase in insoluble solids, and the associated increase in noble metals. The increase in insoluble solids is believed to cause increased consumption of acid, i.e. to make the stoichiometric factor appear to be lower than expected (less excess acid available). Extensive testing with noble metals has indicated that an increase in noble metals tends to make the stoichiometric factor appear to be higher than expected with respect to nitrite destruction and hydrogen generation (more excess acid available). Apparently, the noble metals accelerate the effective use of the acid during processing. The two main differences between SB3 simulant sludge and SB3 radioactive sludge are, therefore, partially off-setting with respect to SRAT processing.

\section{E.2 SRAT Processing Results Comparison}

Off-gas composition data was collected during the two flowsheet simulant runs, SB3A-19 at $125 \%$ acid and SB3A-20 at $155 \%$ acid, as well as during the Shielded Cells SRAT runs. The first figure below compares the carbon dioxide generation rate, in DWPF-scale lbs./hr., from the two simulant runs and the second Cells SRAT run. 
WSRC-TR-2004-00050

\section{Revision 0}

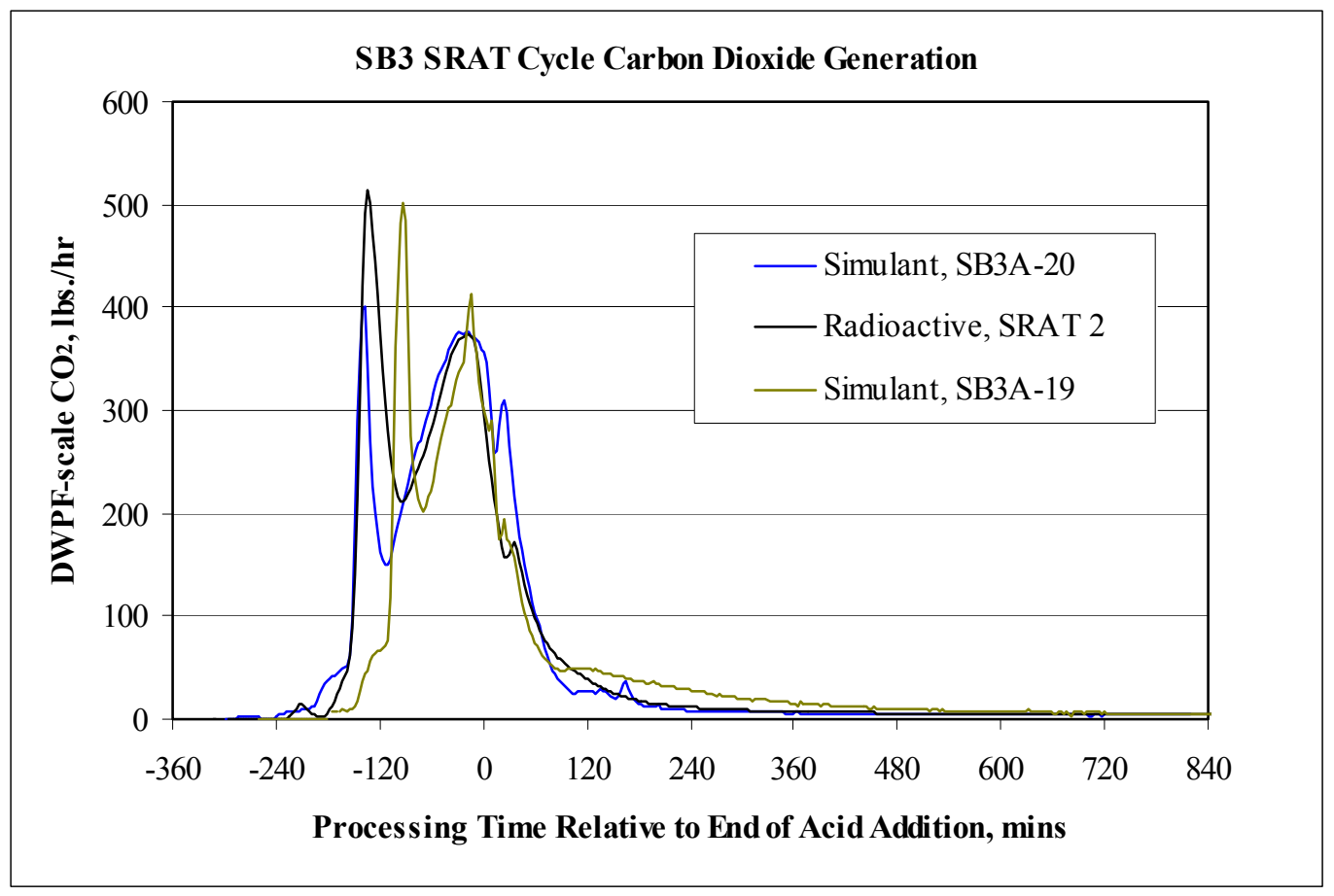

The carbon dioxide generation profiles were very similar. There were two primary peaks in carbon dioxide generation in all three tests. The first came about two hours before the end of acid addition, and the second came near the end of acid addition. The second peak seems to correlate in time with nitrous oxide generation. Nitrous oxide generation occurs by the following reaction:

$2 \mathrm{HNO}_{2}+2 \mathrm{HCOOH} \rightarrow \mathrm{N}_{2} \mathrm{O}+2 \mathrm{CO}_{2}+3 \mathrm{H}_{2} \mathrm{O}$

which implies two pounds of $\mathrm{CO}_{2}$ production for every pound of $\mathrm{N}_{2} \mathrm{O}$ made. The first carbon dioxide peak may correlate with carbonate destruction. The figure below gives the corresponding nitrous oxide generation data for these three SRAT cycles. 


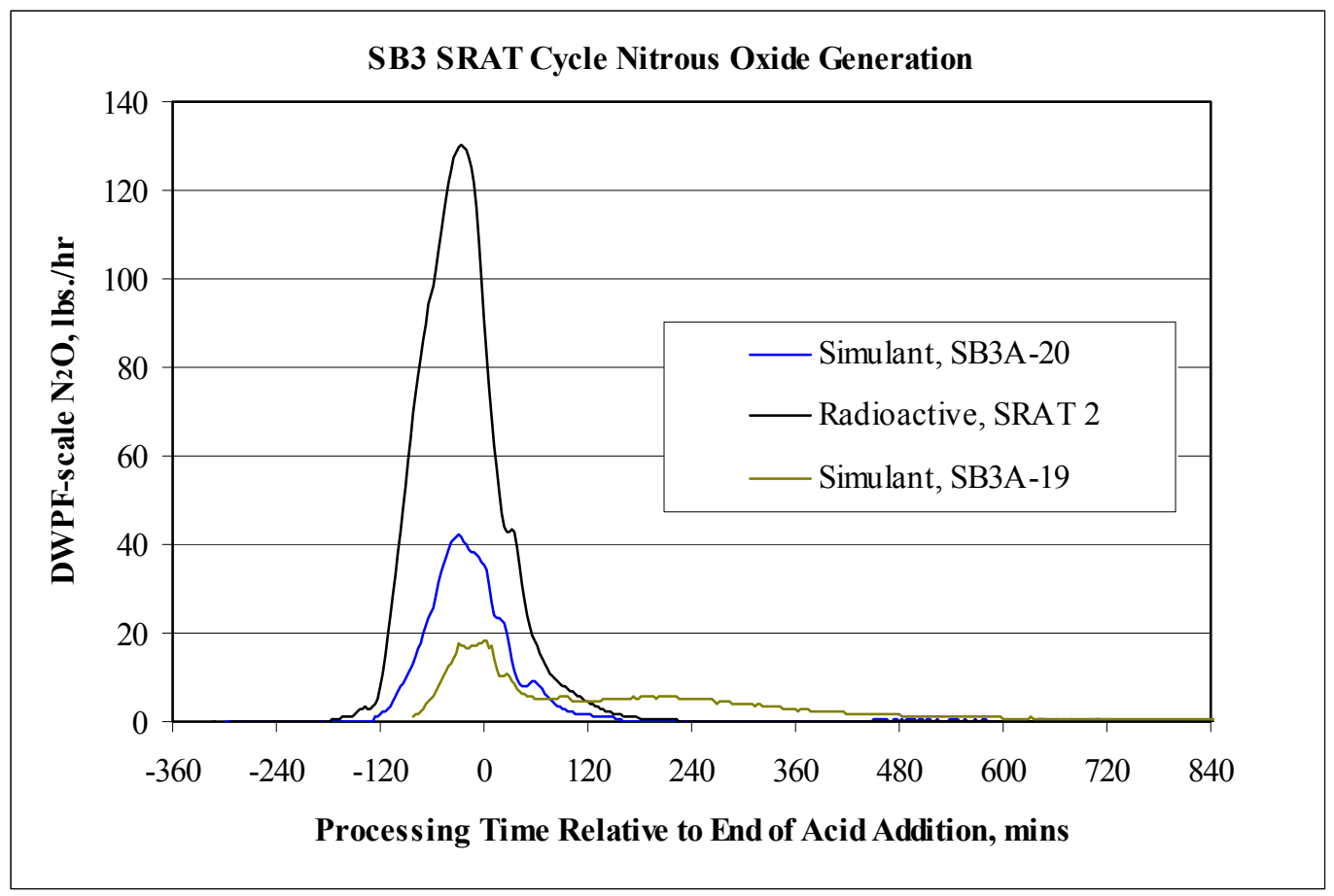

Nitrous oxide generation peaked in all three runs near the end of acid addition. There was considerably more nitrous oxide produced in the Shielded Cells run than in the two simulant runs. Simulant results for nitrous oxide were only mildly impacted by noble metal concentrations, acid stoichiometry, and wash endpoint selection. SB3 simulant results from 11 SRAT cycles were similar to those shown in the figure below for the final two flowsheet simulations. The reason for the higher $\mathrm{N}_{2} \mathrm{O}$ production in the Cells SB3 SRAT cycle has not been identified.

Nitrite that is not converted into nitrous oxide, $\mathrm{N}_{2} \mathrm{O}$, is typically converted into NO within the slurry. This $\mathrm{NO}$ reacts with oxygen in the SRAT vapor space to convert to $\mathrm{NO}_{2}$. Some of the $\mathrm{NO}_{2}$ is then dimerized to $\mathrm{N}_{2} \mathrm{O}_{4}$. $\mathrm{NO}$ is formed by two different routes

$3 \mathrm{HNO}_{2} \rightarrow \mathrm{HNO}_{3}+2 \mathrm{NO}+\mathrm{H}_{2} \mathrm{O}$

and

$$
2 \mathrm{HNO}_{2}+\mathrm{HCOOH} \rightarrow \mathrm{CO}_{2}+2 \mathrm{NO}+2 \mathrm{H}_{2} \mathrm{O}
$$

Neither $\mathrm{NO}$ nor $\mathrm{NO}_{2}$ are monitored with the current generation $\mathrm{GC}$, however the effect of $\mathrm{NO}$ conversion to $\mathrm{NO}_{2}$ can be detected in the oxygen data. The figure below shows the depletion of oxygen during the three SRAT cycles discussed above. 


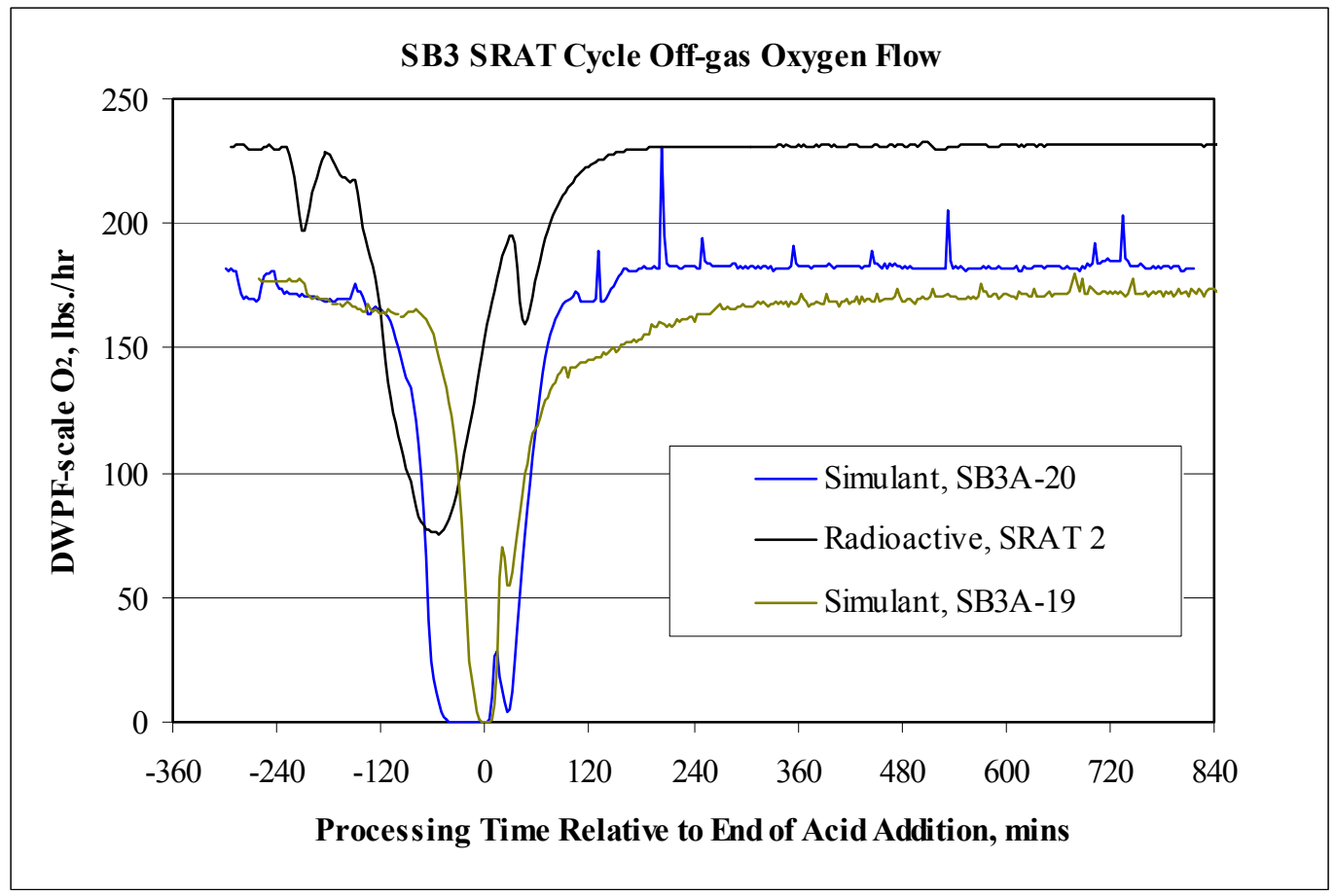

The Shielded Cells inlet oxygen flow was adjusted to match $230 \mathrm{scfm}\left(70^{\circ} \mathrm{F}, 1 \mathrm{Atm}\right)$ of purge air. The simulant oxygen flows were matched to $188 \mathrm{scfm}$ of purge air. This caused an increase in oxygen flow in the Cells SRAT run relative to the simulant runs. Once an allowance for this was made, the oxygen offgas flow profiles were quite similar between the Cells and simulant SRAT runs. The drop in $\mathrm{O}_{2}$ flow was about $150 \mathrm{lbs} . / \mathrm{hr}$ in the Cells run versus about $180 \mathrm{lbs} . / \mathrm{hr}$ in the simulant runs. The somewhat smaller Cells drop may be correlated with the relatively higher conversion of nitrite to $\mathrm{N}_{2} \mathrm{O}$ than to NO in the Cells run. Nitrous oxide formation does not require oxygen consumption.

The timing of the simulant minima correspond closely with the time of the $\mathrm{N}_{2} \mathrm{O}$ maxima, even though $\mathrm{N}_{2} \mathrm{O}$ generation does not require oxygen. That is, there is no chemical reason for the two to occur precisely together. The timing of the Cells oxygen minimum seems to be about an hour ahead of the $\mathrm{N}_{2} \mathrm{O}$ maximum. This may relate to $\mathrm{pH}$ changes, but $\mathrm{pH}$ data is not available for the Cells run. NO formation can occur once the system becomes acidic enough to form nitrous acid. This may have occurred sooner in the Cells run than in the simulant runs due to differences in the acid-insoluble solids reaction rates and/or because of the higher acid addition quantity (stoichiometric demand was higher as described earlier in this appendix). The dip in oxygen in SB3A-20 occurred before the dip in SB3A-19. The quantity of acid that had been added at the time of the two dips was similar, however, i.e. the $\mathrm{pH}$ should have been about the same at the time of both simulant dips.

Observed peak generation rates were similar for hydrogen and carbon dioxide, but not for nitrous oxide as summarized in the table below.

Off-gas Generation Comparison Table

\begin{tabular}{|l|l|l|l|}
\hline & Cells SRAT 2 & SB3A-19 & SB3A-20 \\
\hline Peak $\mathrm{H}_{2}$, DWPF lbs./hr & 0.017 & 0 & 0.014 \\
\hline Peak $\mathrm{CO}_{2}$, DWPF lbs./hr & 516 & 502 & 400 \\
\hline Peak $\mathrm{N}_{2} \mathrm{O}$, DWPF lbs./hr & 131 & 19 & 42 \\
\hline
\end{tabular}


The figure below gives a comparison of the SRAT 2 hydrogen data from the Shielded Cells with the hydrogen data from the final flowsheet simulation, SB3A-20. The simulant run at lower total acid, SB3A-19, did not produce detectable SRAT cycle hydrogen.

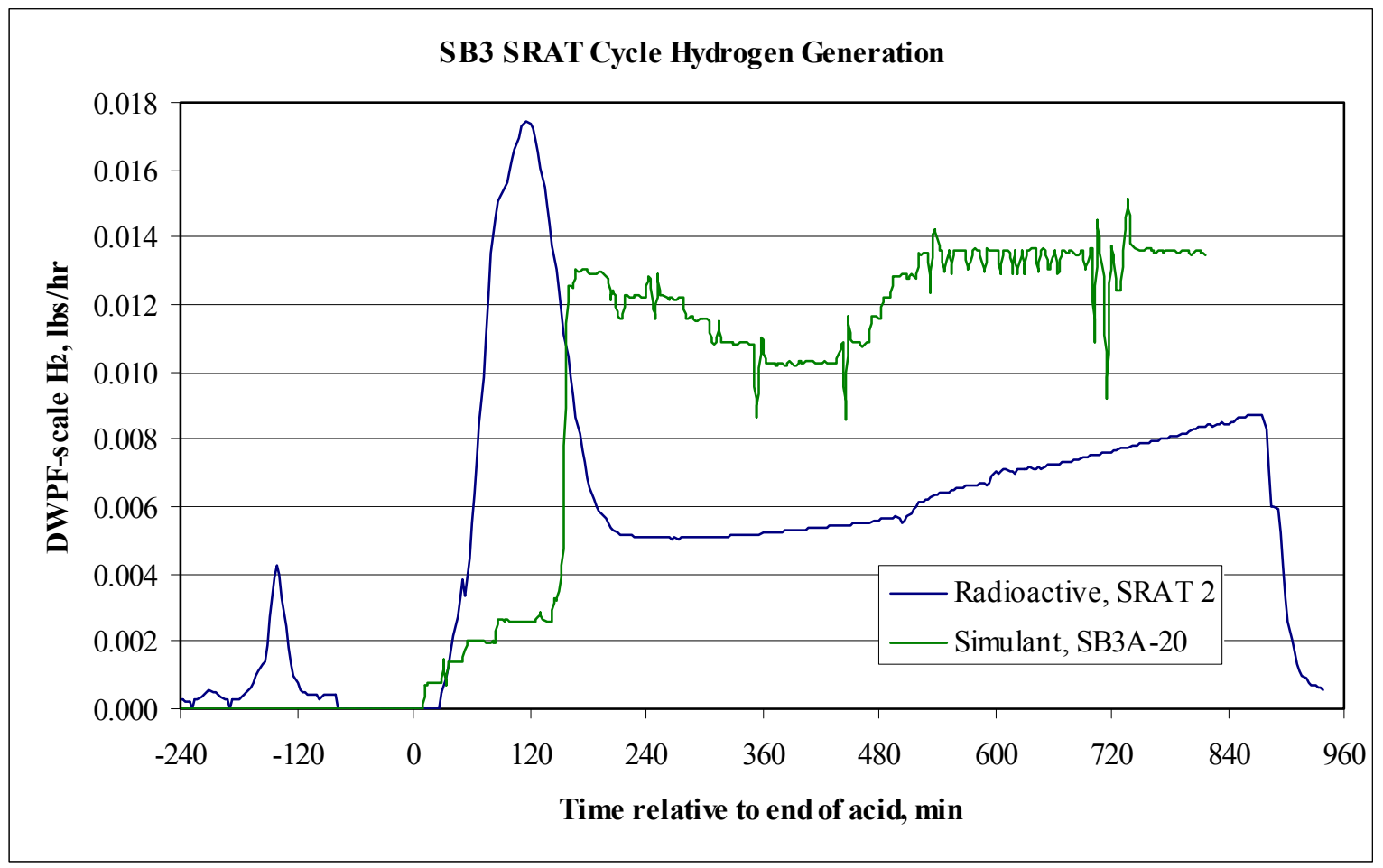

The somewhat more jagged appearance of the simulant data is due to round-off of the integrated peak area to \pm 0.001 volume \% by the software. Both the Cells and simulant runs had a peak in hydrogen generation shortly after acid addition. Each peak was followed by a dip. The hydrogen generation rate then increased slowly until the end of the SRAT reflux period. The behavior of these two runs was quite similar, given that the stoichiometric acid additions were 141\% in the Cells and $155.5 \%$ for SB3A-20. This may relate to the partially off-setting effects of lower stoichiometry, higher insoluble solids levels, and higher noble metal concentrations discussed earlier in this appendix.

There was a small hydrogen generation peak in the Cells run during formic acid addition. There was no corresponding peak in the simulant runs, nor has there been a peak there in any simulant data taken during the last five years. This Cells peak came after the accumulated radiolytic hydrogen had been purged from the vessel. Something similar happened during the SB3 SRAT 1 acid addition, but there was still some residual radiolytic hydrogen present. Consequently the effect was not as distinct.

Analyses were made on the radioactive and simulant SRAT products. Comparisons of the radioactive and simulant SRAT product results are given below. 
SRAT Product Anion Comparison

\begin{tabular}{|l|l|l|l|}
\hline & SB3A-19 & SB3A-20 & SRAT 2 \\
\hline Nitrite, $\mathrm{mg} / \mathrm{kg}$ slurry & 1635 & $<500$ & $<200$ \\
\hline Nitrate, $\mathrm{mg} / \mathrm{kg}$ slurry & 31,950 & 39,700 & 38,100 \\
\hline Formate, $\mathrm{mg} / \mathrm{kg}$ slurry & 57,000 & 61,300 & 61,700 \\
\hline Oxalate, $\mathrm{mg} / \mathrm{kg}$ slurry & 1480 & 1785 & 1110 \\
\hline
\end{tabular}

SRAT 2 nitrate and formate are quite close to the simulant run, SB3A-20. Although SB3A-20 was at $155.5 \%$ of stoichiometric acid, while SRAT 2 was at $141 \%$ acid, the Cells SRAT 2 had a $15.6 \%$ higher stoichiometric acid requirement as described earlier in this appendix. The higher stoichiometric demand and lower \% excess came close to canceling out: $141 * 115.6=163$ which is only $5 \%$ more than 155.5 . This helps to explain why the nitrate and formate concentrations are nearly identical.

The table below compares general properties of the simulant and radioactive SRAT properties.

SRAT Product Properties Comparison

\begin{tabular}{|l|l|l|l|}
\hline & SB3A-19 & SB3A-20 & SRAT 2 \\
\hline Total Solids (wt. \% of slurry) & 25.4 & 25.8 & 29.9 \\
\hline Insoluble Solids & 12.0 & 10.5 & 15.4 \\
\hline Soluble Solids & 13.4 & 15.3 & 14.6 \\
\hline Calcined Solids & 15.3 & 15.0 & 19.8 \\
\hline Slurry Density & 1.19 & 1.21 & 1.27 \\
\hline Supernate Density & 1.12 & 1.10 & 1.14 \\
\hline pH (product sample) & 7.50 & 6.09 & 5.2 \\
\hline pH (probe in SRAT, end of SRAT) & 6.62 & 5.49 & - \\
\hline
\end{tabular}

SRAT product properties were generally as expected based on the starting sludges. The main difference between simulant and radioactive results was in the total, insoluble, and calcined wt. \% solids. These were uniformly higher in the Cells SRAT 2 data $(\sim+4 \%)$, due to the higher wt. $\%$ total solids of the starting radioactive sludge relative to the simulant. Soluble solids and supernate density were quite close. The simulant $\mathrm{pH}$ differences between the SRAT vessel probe and the Mobile Lab probe have been observed before. The Shielded Cells SRAT 2 run received 5\% more acid than SB3A-20, and could be expected to have the lowest $\mathrm{pH}$, everything else being equal.

\section{E.3 SME Cycle Comparison}

The SB3 Shielded Cells SME cycle simulated five canister decontamination water additions and the associated de-watering. This was followed by the addition of the appropriate mass of frit-formic acidwater slurry in two equal portions with intermediate de-watering steps. The SME was put into reflux following the final de-watering to monitor off-gas composition. The most equivalent simulant run was SB3A-20, in terms of starting composition. This SME cycle did not simulate canister decon water addition and dewatering, and went directly to the frit-formic acid-water slurry addition in equal thirds. It was also put into reflux following final de-watering to monitor off-gas composition.

The figure below compares the hydrogen generation rate data for these two SME cycles. 


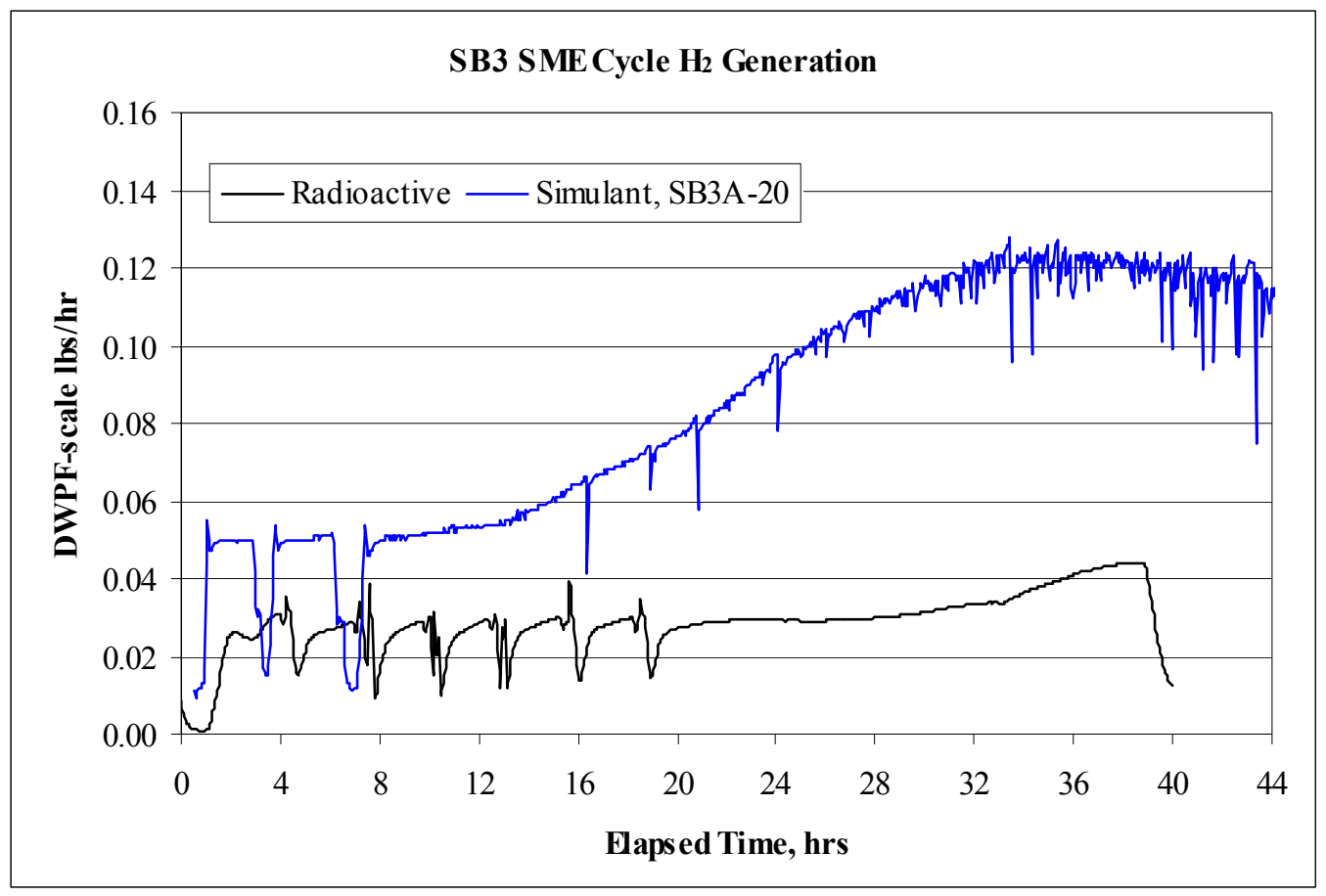

The simulant run hydrogen generation held fairly steady through the three frit slurry additions and dewatering steps, then slowly crept up during the reflux period to about half of the DWPF SME cycle design basis limit. The Cells SME cycle seemed to want to increase hydrogen generation each time it was brought back to boiling, but it never got very far before getting cooled down by another addition. It finally started to rise at about hour 33 into the SME cycle, but rose only a little before reaching the 40 hour maximum likely time at boiling for a typical SME cycle. Simulant hydrogen generation was greater than the radioactive run. This continued the relative relationship between simulant (SB3A-20) and radioactive (SRAT 2) cases seen at the end of the SRAT cycle.

The following table compares anion concentrations of the radioactive and simulant SME products.

SME Product Anion Comparison

\begin{tabular}{|l|l|l|l|}
\hline & SB3A-19 & SB3A-20 & Cells \\
\hline Nitrite, $\mathrm{mg} / \mathrm{kg}$ slurry & 362 & $<500$ & $<100$ \\
\hline Nitrate, $\mathrm{mg} / \mathrm{kg}$ slurry & 33,909 & 40,350 & 24,800 \\
\hline Formate, $\mathrm{mg} / \mathrm{kg}$ slurry & 62,900 & 63,500 & 34,700 \\
\hline Oxalate, $\mathrm{mg} / \mathrm{kg}$ slurry & 1158 & 1840 & 519 \\
\hline
\end{tabular}

The radioactive data was obtained on a supernate sample and converted to a slurry basis. The anion values appear to be universally lower than expected based on the simulant work.

The table below compares general properties of the simulant and radioactive SME products. 
WSRC-TR-2004-00050

Revision 0

SME Product Properties Comparison

\begin{tabular}{|l|l|l|l|}
\hline & SB3A-19 & SB3A-20 & SRAT 2 \\
\hline Total Solids (wt. \% of slurry) & 53.8 & 51.8 & 47.9 \\
\hline Insoluble Solids & 38.7 & 36.3 & 38.1 \\
\hline Soluble Solids & 15.1 & 15.5 & 9.9 \\
\hline Calcined Solids & 43.5 & 40.9 & 40.7 \\
\hline Slurry Density & 1.54 & 1.54 & 1.44 \\
\hline Supernate Density & 1.18 & 1.18 & 1.12 \\
\hline pH (product sample) & 7.61 & 6.98 & \\
\hline
\end{tabular}

The target waste loading for the Cells SME cycle was 35\% sludge oxides in glass. The target for the simulant runs was $38 \%$. This does not help to explain the seemingly low value for the soluble solids in the Cells SME product. This is, however, consistent with the low supernate density and the low formate and nitrate anion results.

Two things happened that would cause such differences based on the run data. The Cells SME product contains about $92 \%$ of the total solids as SB3A-20 (ratio of total solids). The Cells SME solids appear to be only about $44.5 \%$ due to SRAT product compared to $51.5 \%$ for SB3A-20 (differences in calcine factor and waste loading target). Consequently, the SRAT product contribution to SME product total solids is roughly only $79 \%$ of that for SB3A-20. (The SRAT product is the source of the majority of the dissolved solids.) This is still not a large enough effect to explain the entire difference between the simulant and SME product properties, although it can explain about half of it. One other possibility is that the Cells SME supernate sample may have been accidentally contaminated with a small quantity of extra water that diluted the dissolved solids. A third possibility is that there was a significant loss of nitrate and formate during the Cells SME cycle. Formate loss would be the easier of the two to accept, since there was hydrogen and carbon dioxide generation, but SB3A-20 had these as well. Small nitrate losses have been observed in simulant SME cycles. The implied Cells nitrate loss appears to be more significant than anything seen in typical simulant SME cycles. 
WSRC-TR-2004-00050

Revision 0

APPENDIX G. MASS BALANCE AND ANION DESTRUCTION CALCULATIONS 
WSRC-TR-2004-00050

Revision 0

\begin{tabular}{|c|c|c|c|c|c|}
\hline & & \multicolumn{3}{|c|}{ Concentrations (slurry basis) } & \multirow[b]{2}{*}{$\begin{array}{l}\text { Oxalate } \\
(\mathrm{mg} / \mathrm{kg})\end{array}$} \\
\hline & & $\begin{array}{l}\text { Nitrite } \\
(\mathrm{mg} / \mathrm{kg})\end{array}$ & $\begin{array}{l}\text { Nitrate } \\
(\mathrm{mg} / \mathrm{kg})\end{array}$ & $\begin{array}{l}\text { Formate } \\
(\mathrm{mg} / \mathrm{kg})\end{array}$ & \\
\hline SRAT Feed & 417 & 25,300 & 19,600 & $<400$ & 2,000 \\
\hline Nitric Acid & 8.15 & & 494,000 & & \\
\hline Formic Acid & 38.48 & & & 840,000 & \\
\hline Flush Water & 10 & & & & \\
\hline Dewater & -48 & & & & \\
\hline SRAT Product & 426 & 0 & 38,100 & 61,700 & 1,200 \\
\hline Sample & -80.79 & 0 & 38,100 & 61,700 & 1,200 \\
\hline SME Feed & 345 & 0 & 38,100 & 61,700 & 1,200 \\
\hline Frit & 127 & & & & \\
\hline 1.5 wt $\%$ Formic Acid & 127 & & & 14,700 & \\
\hline Dewater & -125 & & & & \\
\hline \multirow[t]{18}{*}{ SME Product } & 474 & 0 & 24,800 & 34,700 & 900 \\
\hline & & & & & \\
\hline & & Nitrite & Nitrate & Formate & Oxalate \\
\hline & SRAT Feed $(\mathrm{g})$ & 10.55 & 8.17 & 0.00 & 0.83 \\
\hline & Added Acid (g) & 0.00 & 4.03 & 32.33 & 0.00 \\
\hline & SRAT Product (g) & 0.00 & 16.22 & 26.26 & 0.51 \\
\hline & g created (consumed) & $(10.55)$ & 4.02 & $(6.07)$ & $(0.32)$ \\
\hline & $\%$ created (consumed) & $(100 \%)$ & $33 \%$ & $(19 \%)$ & $(39 \%)$ \\
\hline & Nitrite to Nitrate & & $28 \%$ & & \\
\hline & & & & & \\
\hline & SME Feed $(\mathrm{g})$ & 0.00 & 13.14 & 21.28 & 0.41 \\
\hline & Additions (g) & & & 1.87 & \\
\hline & SME Product (g) & 0.00 & 11.75 & 16.44 & 0.43 \\
\hline & g created (consumed) & 0.00 & (1.39) & $(6.70)$ & 0.01 \\
\hline & $\%$ created (consumed) & $0 \%$ & $(11 \%)$ & $(29 \%)$ & $0 \%$ \\
\hline & Overall & $(100 \%)$ & $19 \%$ & $(42 \%)$ & $(39 \%)$ \\
\hline & & & & & \\
\hline & Overal Nitrite to nitrate & & $25 \%$ & & \\
\hline
\end{tabular}

Notes:

- $\quad$ Created/consumed for each cycle $=$ (mass in product - mass added - mass in feed $) /$ mass in feed.

- Overall created/consumed $=1$ - fraction remaining after SRAT x fraction remaining after SME or 1 (1- fr created/consumed in SRAT) x (fr created/consumed in SME)

- $\quad$ SRAT cycle Nitrite to nitrate conversion $=$ moles nitrate created $/$ moles nitrite consumed

- Overall nitrite to nitrate conversion $=$ SRAT nitrite to nitrate $\mathrm{x}(1-\mathrm{fr}$ consumed in SME $)$ 
WSRC-TR-2004-00050

Revision 0

This page intentionally left blank. 
This page was intentionally left blank 